\title{
Cultural Resources Survey: Freeport, Harbor, Texas, (45-Foot) Navigation Improvement Project, Brazoria County, Texas
}

Anne A. Fox

James E. Ivey

J. Carroll Markey

Follow this and additional works at: https://scholarworks.sfasu.edu/ita

Part of the American Material Culture Commons, Archaeological Anthropology Commons, Environmental Studies Commons, Other American Studies Commons, Other Arts and Humanities Commons, Other History of Art, Architecture, and Archaeology Commons, and the United States History Commons

Tell us how this article helped you.

This Article is brought to you for free and open access by the Center for Regional Heritage Research at SFA ScholarWorks. It has been accepted for inclusion in Index of Texas Archaeology: Open Access Gray Literature from the Lone Star State by an authorized editor of SFA ScholarWorks. For more information, please contact cdsscholarworks@sfasu.edu. 


\section{Cultural Resources Survey: Freeport, Harbor, Texas, (45-Foot) Navigation Improvement Project, Brazoria County, Texas}

\section{Creative Commons License}

(c) (i) (8)

This work is licensed under a Creative Commons Attribution-NonCommercial 4.0 International License 
CULTURAL RESOURCE SURVEY

FREEPORT HARBOR, TEXAS (45-FOOT) NAVIGATION

IMPROVEMENT PROJECT

BRAZORIA COUNTY, TEXAS

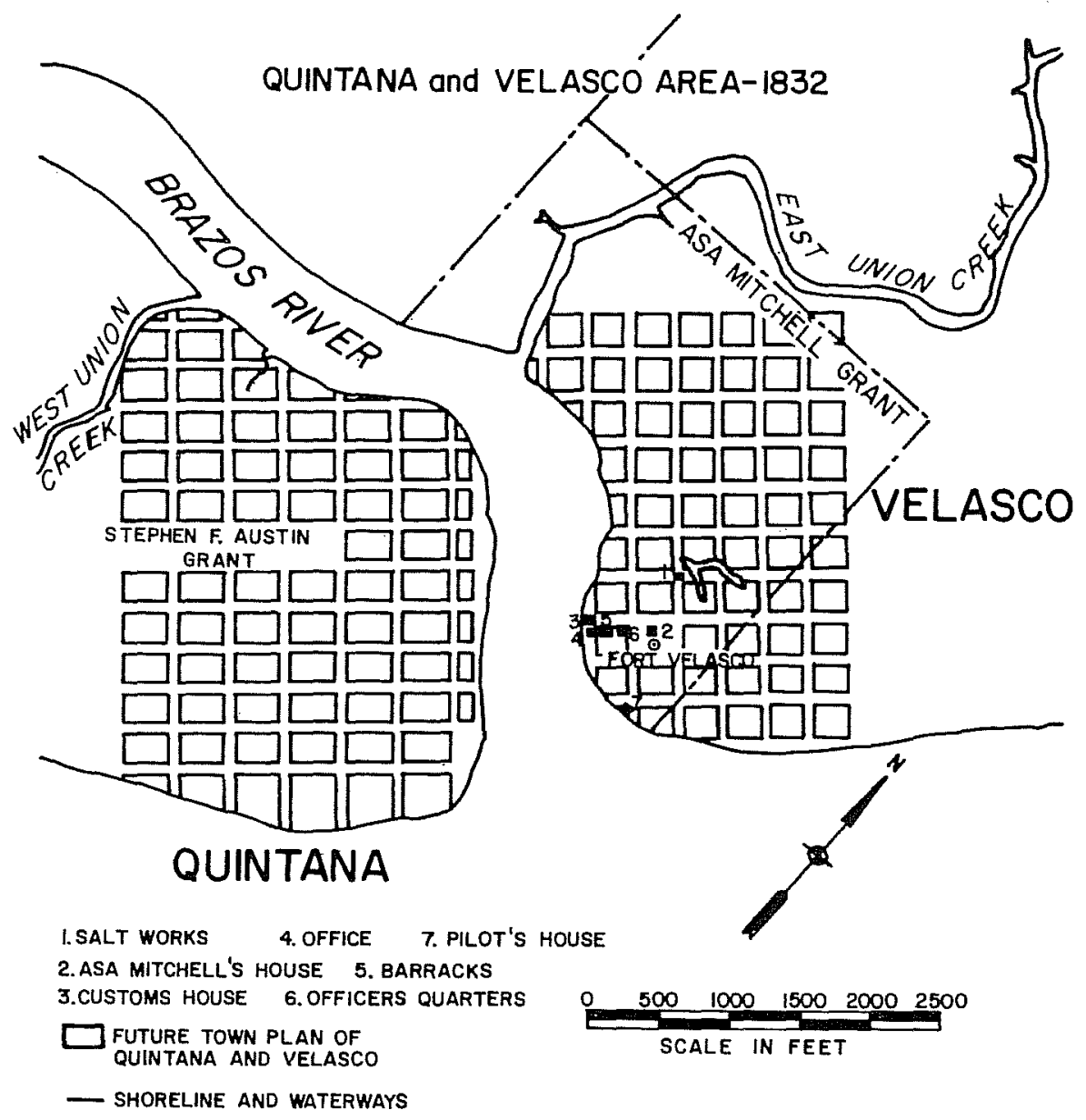

Anne A. Fox, James E. Ivey, and J. Carroll Markey

CENTER FOR ARCHAEOLOGICAL RESEARCH THE UNIVERSITY OF TEXAS AT SAN ANTONIO ARCHAEOLOGICAL SURVEY REPORT, NO. 107

1981

PREPARED FOR:

THE U.S. ARMY CORPS OF ENGINEERS, GALVESTON DISTRICT 



\title{
CULTURAL RESOURCE SURVEY
}

FREEPORT HARBOR, TEXAS (45-FOOT) NAVIGATION

IMPROVEMENT PROJECT

BRAZORIA COUNTY, TEXAS

\author{
Anne A. Fox, James E. Ivey, and J. Carrol: Markey \\ Principal Investigators: \\ Thomas R. Hester, Director \\ Jack D. Eaton, Associate Director
}

\author{
Submitted to: \\ U.S. Corps of Engineers \\ Galveston District \\ Contract No. DACW64-80-C-0061
}

Center for Archaeological Research The University of Texas at San Antonio Archaeological Survey Report, No. 107

1981 

1. Archaeological survey, testing, and historical research in the Freeport Harbor area;

2. Freeport Harbor, (45-Foot) Navigation Improvement project;

3. Brazoria County, Texas;

4. Thomas R. Hester, principal investigator; Anne A. Fox, co-principal investigator; James E. Ivey, field director;

5. GaTveston District, U.S. Corps of Engineers, Contract No. DACW6480-C-0061. 


\section{ABSTRACT}

In October and November of 1980 , the Center for Archaeological Research, The University of Texas at San Antonio, conducted an intensive resource survey and limited testing in an area on either side of the mouth of the Brazos River in Brazoria County, Texas. A history was composed of the project area in relation to that of the Republic and State of Texas. A structural history of the town of Velasco was compiled from archival and historical research. Intensive survey and assessment of the project area resulted in the conclusion that, aside from a few possible subsurface indications at or below the water level, Fort Velasco and the townsite of Velasco have been eliminated by the action of successive tropical storms. It is recommended, however, that further intensive testing be carried out if the area within Monument Square of old Velasco is to be seriously impacted by the Freeport Harbor Navigation Improvement Project. 
TABLE OF CONTENTS

Page

ABSTRACT ......................

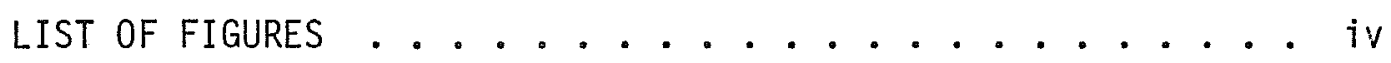

LIST OF TABLES ....................... iv

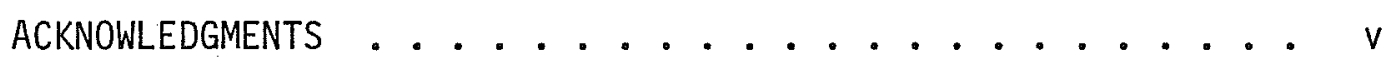

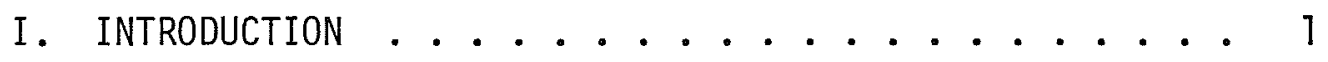

Scope of Work . . . . . . . . . . . 1

Regional Location ............. 2

Previous Work in the Area ......... 3

II. LITERATURE AND ARCHIVAL RESEARCH . . . . . . 6

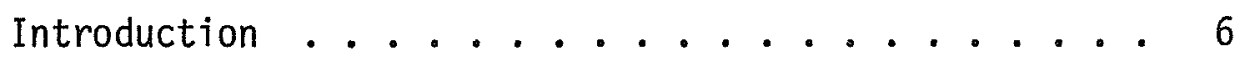

Historical Narrative .......... . 6

Structural Research . . . . . . . . . . 30

III. INTENSIVE SURVEY AND ASSESSMENT . . . . . . . . . 40

Methodology . . . . . . . . . . 40

Field Work . . . . . . . . . . . . 42

IV. ARTIFACT DESCRIPTIONS ............... 53

Kitchen/Dining Activities . . . . . . . . 53

Household Items . . . . . . . . . . 61

Personal Items and Activities ........ . . 66

Barn/Workshop ............ 70

Arms ...................... 70

Building Materials ............. 71 
SUMMARY STATEMENT ...................... 72

RECOMMENDATIONS ................................. 74

REFERENCES CITED . . . . . . . . . . 75

APPENDIX I: Assessment of Surfside Structures . . . . . 87

APPENDIX II: Assessment of Coast Guard Station . . . . . . 91 


\section{LIST OF FIGURES}

Page

1. Freeport Harbor Project Survey Area . . . . . . . . . 5

2. Texas Coastal Area, 1845 .............. 7

3. Schematic of Lot Exchanges in 1837 . . . . . . . . 31

4. Quintana and Velasco Area - 1832 . . . . . . . 35

5. Quintana and Velasco Area - 1852 . . . . . . . 36

6. Quintana and Velasco Area - 1890 . . . . . . . 37

7. Surfside (01d Velasco) and Quintana Today . . . . . 39

8 Freeport Harbor Project: Unit Locations . . . . . . . . 41

9. Monument Square Units, Plan View .......... 43

10. Monument Square Excavations, Photographs . . . . . . 45

11. Excavation Areas, General Views . . . . . . . . . 47

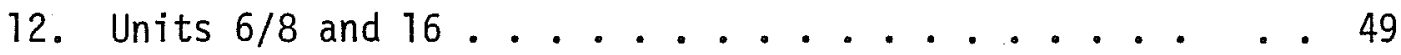

13. Various Ceramics and Glass Containers . . . . . . 55

14. Transferwares and Whitewares . . . . . . . . . 57

15. Dark Green Bottles and Whole Bottles . . . . . . . . . 63

16. Pressed Glass, Table and Kitchenwares,
Barn/Workshop Items . . . . . . . . . . 65

17. Construction, Arms, Clothing, Personal
and Household Items . . . . . . . . . 69

18. Photographs of Recorded Structures . . . . . . . . 88

19. Photographs of Lifeboat Station . . . . . . . . . 93

\section{LIST OF TABLES}

1. Structural History of Velasco: An Outline . . . . . . 34

2. Artifact Provenience Freeport Harbor Project . . . . . 58 


\section{ACKNOWLEDGMENTS}

Special thanks are due to many local residents who shared freely of their knowledge of the history of the area, and helped in numerous ways to make our work easier and our stay more pleasant in the community. We remember with gratitude Angie Brannon, Lagett Cleaver, Howard Fearn, Ted Hollingsworth, George Kramig, Dr. "Mac" MacAlexander, Dan Parkinson, Johnny Pollan, and I. E. Rasmussen for their encouragement and support. Warren Lynn and Frank Hole gave us the benefit of their experience in working at Quintana, which was most helpful. 0.I.N.C. Sherman E. Rowe of the Life Saving Station and his staff were helpful in many ways, and we appreciate their offer of a safe storage place for tools and equipment. Librarians at the Brazoria County Library in Angleton and the staff of the County Clerk's office in the Brazoria County Courthouse were most pleasant and helpful.

In particular we appreciate the cheerful patience of Ernest Wittig and Carolyn Good of the Corps of Engineers, Galveston District, and the staff of that office.

Principal Investigators for the project were Thomas R. Hester, Center Director, and Jack D. Eaton, Associate Director. Anne A. Fox was CoPrincipal Investigator and director and James $E$. Ivey the field director. A vote of thanks to the long-suffering crew members, Lois Flynn, Kathy Bareiss Roemer, Rebekah Halpern and Waynne Cox, who managed to stay enthusiastic and cheerful despite tropical storms, rising waters and confusing or nonexistent stratigraphy.

The senior author is particularly appreciative of the work of historical consultant J. Carrol1 Markey, who took a large, unruly stack of research notes, compiled throughout the project, and produced an interesting and coherent essay on the history of the project area in relation to that of the Republic and State of Texas. We are also grateful to translator Dora Guerra, of the John Peace Library of The University of Texas at San Antonio, for translating Ugartechea's report of the Battle of 1832 for our use.

The writing of the final report was divided among the authors in the following manner. Sections I, II, and IV were written by Fox. In Section II, Markey wrote the Historical Narrative and Ivey the portion on Structural Research. Ivey also wrote The Summary Statement and Recommendations and supervised the compilation and construction of the maps and drawings. Kathy Bareiss Roemer of the Center staff drafted the maps and drawings for the report.

This manuscript was edited by Thomas R. Hester and Sharon Quirk, and the typist was Patricia Wallace. 


\section{INTRODUCTION}

On September 19, 1980, the Center for Archaeological Research (CAR) entered into a contract with the U.S. Army Corps of Engineers, Galveston District (Contract No. DACW64-80-C-0061), to conduct a cultural resource survey of the Freeport Harbor Navigation Improvement Project in Brazoria, Texas. This project will deepen, realign and enlarge the present channel entrance and the inside main channels and turning basins. The north jetty will be relocated, as will the U.S. Coast Guard Station. Additional work will include rehabilitation of the south jetty, and the construction of shore protection, breakwaters and public use facilities.

\section{Scope of Work}

As specified by the U.S. Army Corps of Engineers (1980:Appendix A, Section II) in the contract, the assignment was to conduct an intensive cultural resource survey and assessment of the project area, to identify cultural resources within the area, evaluate their significance and assess primary and secondary impacts to these resources which would result from project construction.

In order to accomplish these objectives, the following tasks were to be done:

1. A thorough literature and archival search of the project area.

2. An intensive field survey of the entire project area to identify all cultural resources.

3. An assessment of project impact to all identified cultural resources in the project area.

4. An assessment of potential National Register eligibility of all identified cultural resources in the project area including the proposed Fort VelascoQuintana Historic District.

5. The thorough testing and evaluation of the presumed location of Fort Velasco within the project area.

6. An architectural and historical assessment of the U.S. Coast Guard Station complex at Surfside on the east side of the channel.

7. The subsurface testing and assessment of a threeacre tract of land where the U.S. Coast Guard Station will be relocated.

In order to most efficiently accomplish the work assigned by this contract, the project was to be divided into three parts: (1) a literature 
and archival search; (2) an intensive field survey, limited testing, and assessment; and (3) the preparation of a comprehensive report of the work. The results of the assessment of the Coast Guard Station and the area where it is to be relocated were reported to the U.S. Army Corps of Engineers, Galveston District, in March 1981 (Fox 1981). This report comprises the results of the balance of the project.

\section{Regional Location}

The area of concern to this project includes the low-lying lands on either side of the mouth of the Brazos River. The survey area is less than 5 feet above sea level, except for a number of large spoil mouna: near the Gulf on the southwest side of the channel, and one less noticeable mound east of the Coast Guard Station on the northeast side.

Vegetation in the area is primarily low-growing, with various grasses and groundcovers, and low shrubs and trees such as oleander and salt cedar predominating. The climate is mild and subtropical, with a mean temperature of $43^{\circ} \mathrm{F}$ in January and $92^{\circ} \mathrm{F}$ in August (Creighton 1975:444). The prevailing Gulf breeze is from the southeast, but occasional cold fronts bring north winds and can drop the temperature $40^{\circ} \mathrm{F}$ in less than an hour (ibid.:443).

Between June and October the area is subject to intense tropical storms which form in the Gulf. A deadly succession of these storms, many of them reaching hurricane velocity, have pounded the coastal area in historic times. The Texas Almanac (1974) 1ists more than 25 severe storms and hurricanes which have impacted the area from Galveston to Corpus Christi between 1818 and the present. Bringing winds of 135 to 175 miles per hour and tides as high as 16 feet or more above sea level, these storms have been a factor of major importance in the history of the Texas Coast and of the mouth of the Brazos River in particular.

Soils consist of red, brown, and gray Pleistocene sands and muds which have been redistributed over the years by intermittent flooding and wave action. Some of this red clay has also been deposited by extensive flooding of the Brazos River after heavy rains, at which time the flood waters would have covered most of the project area.

In the early 19th century, Mary Austin Holley (1808-1846:Letter 1843:28) observed that the waters of the Brazos River would turn brackish for a time after such floods because of the salt deposits located in the upper reaches, and "a fine, red clay, as slippery as soap, and as sticky as putty" was deposited on the flooded areas.

Erosion and deltaic deposition have caused remarkable changes in the shoreline in this area over the past 150 years. The construction of jetties at the mouth of the river beginning in 1889 has had a noticeable effect on the distribution of these deposits, and the shoreline on the Velasco side of the channel has moved 2000 feet to the southeast since 1858 (United States Coastal Survey 1858). Channel dredging and bank 
cutting have also altered the shape and contours of the river banks over the years, eliminating a large portion of what was once the settlement of Quintana (Lynn 1979:Fig. 4).

Today much of the land on either side of the mouth of the Brazos River is gradually reverting to its original barren state. Aside from the Coast Guard Station, the only structures present are beach houses built within the past twenty years or so, nondescript squatters' shacks and early 20th century frame farmhouses which have somehow survived the rigors of the salt air and hurricanes.

Just north of the Coast Guard Station is a small group of frame structures of various ages and stages of decay. Clumps of salt cedars following old fence lines break the incessant southeast breeze. A house-by-house survey failed to find one structure within the project area of sufficient age and status to merit nomination to the National Register of Historic Places (see Appendix I).

The Quintana side has almost entirely returned to a natural state, with the exception of a few shacks and the refurbished Seaburn house.

Previous Work in the Area

The Corps of Engineers has commissioned three previous cultural resource surveys in the project area. A reconnaissance level survey was conducted in 1975 by John E. Ippolito and Edward P. Baxter (1976) from the Texas A\&M Research Foundation. Three historic sites were recorded, two of which were considered potentially eligible for the National Register of Historic Places. These were the site of two World War II gun emplacements on the Quintana side of the channel (41 B0 116) and the postulated site of Fort Velasco (41 B0 125) on the opposite side. The former were easily identified because of their elevated construction. The latter was evidently located for the surveyors by members of the Gulf Coast Chapter, Texas Society of Professional Engineers (Ippolito and Baxter 1976:23-26). It was identified on the basis of brick foundations in the area. More thorough field examination and archival research would have suggested that these foundations were not part of the original fort, which apparently consisted entirely of palisade structures. The collections in the possession of local residents contain artifacts which clearly date from the early 1800s to the present, but nothing was observed which would confirm the presence of a Mexican site.

Magnetometer surveys were conducted to locate underwater remains by Odom Offshore Surveys, Inc., in 1978 and by Fairfield Industries in 1979. A number of magnetic anomalies were recorded. Assessments of selected anomalies were conducted by the National Park Service (Lenihan 1980), Texas A\&M (Bond 1980), and North Texas State University (Hays 1981, report in progress). A11 anomaly sources identified by diving are attributable to modern refuse and wreckage. No pre-20th century resources were identified. 
In addition to the above surveys, Warren M. Lynn (1979) conducted an archaeological survey and testing in the vicinity of Quintana (41 BO 135) in 1969 and 1979 respectively, for the Brazos River Harbor Navigation District. Dr. Frank Hole (report in preparation) subsequently conducted excavations in mitigation of possible damage to be caused by this project on sites located by Lynn. While Lynn found accumulations of artifacts and structural remains in the form of wooden posts and brick chimney bases, the general impression of the results of his excavations is one of disturbed and redeposited materials surrounding securely anchored architectural features. This impression is borne out by the observations of Hole (1980) at the time of his excavations:

The site is, at best, insubstantial in that there is very little depth of deposit and few architectural remains. Across parts of the site the artifacts lie on a distinct layer but through most of the site they are scattered through sandy deposits. When artifacts are on a layer it is usually on sandy loam at the contact with the underlying clays.

In addition to these projects, the Fort Velasco Restoration Association, sponsored by the Gulf Coast Chapter of the Society of Professional

Engineers, carried out land clearing and excavations in the vicinity of several brick foundations in Surfside Block 568 (Fig. 1) in early 1971. Artifacts recovered during these excavations have been examined by the CAR archaeologists of these artifacts, ceramics from the $H$. B. Fearn and John Pollan collections were generously loaned to the CAR for detailed analysis. With the exception of a few Mexican coins, which were probably in circulation throughout Texas in the early 19th century, all of the artifacts are of English, European or American origin. They represent the time period from $\mathrm{ca}$. 1830 to the present, and include a number of military items from the Civil War period.

At the time of the 1971 excavations, a bulldozer was used to clear away clumps of salt cedar and a squatter's shack on the property (Lagett Cleaver, personal communication). A group of Boy Scouts under the direction of Cleaver, Dale Sandlin and $H$. B. Fearn dug out a large brick cistern within the same block. Then in 1972 and 1973 additional excavations were done in Surfside Block 568 by Raymond Walley, a local amateur archaeologist, now deceased. No information was found on the results of these later excavations. 


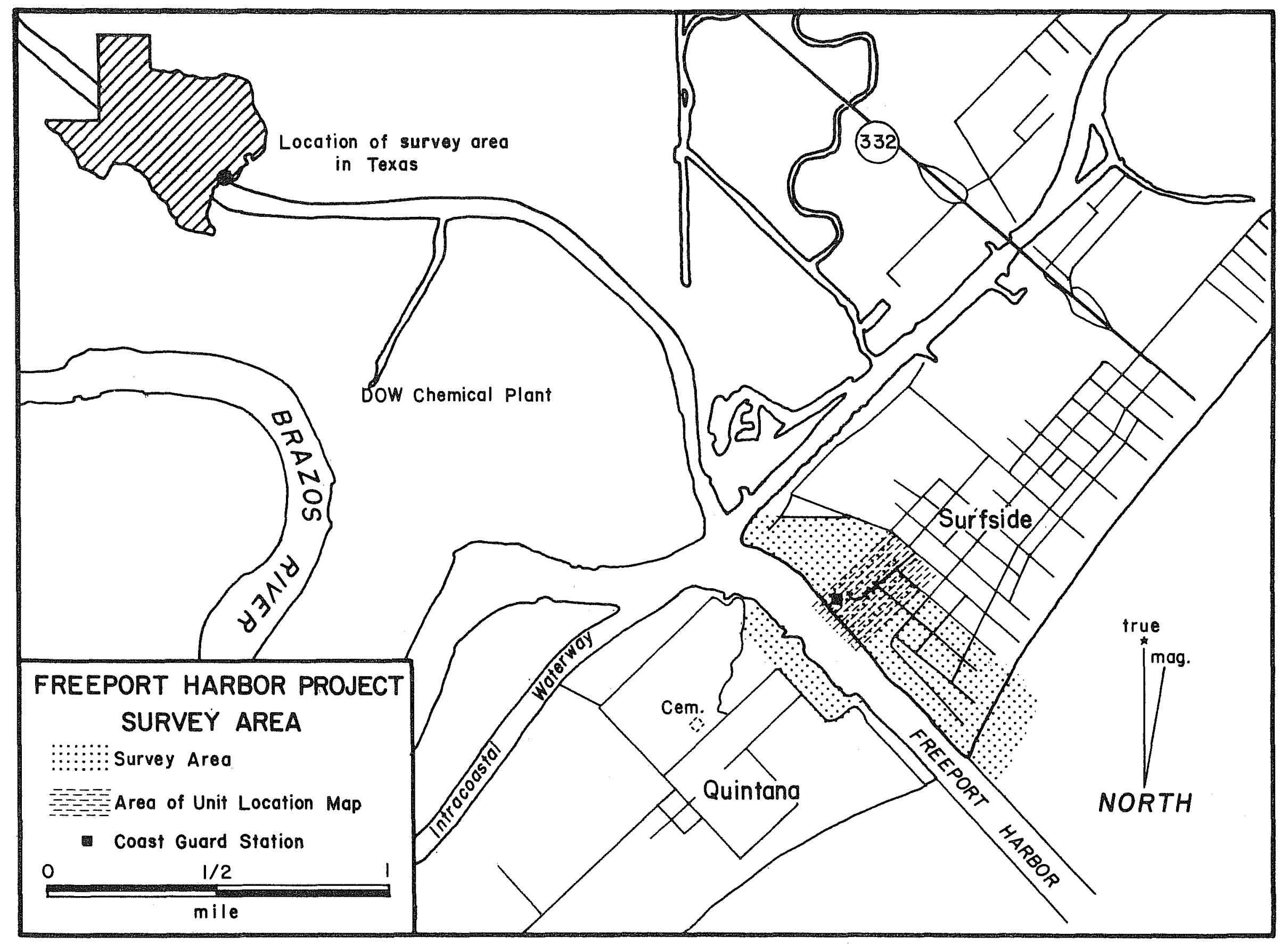

Figure 1. Freeport Harbor Project Survey Area. For location of Velasco, see Figure 7. 


\section{I . LITERATURE AND ARCHIVAL RESEARCH}

Introduction

Despite the fact that a number of cultural resource surveys have been conducted, no comprehensive archival and historical research appears to have been done which deals exclusively and in depth with the area in question. The mouth of the Brazos River has been of considerable importance to Texas history, including as it does the sites of Fort Velasco where the first battle of the Texas revolution was fought, and the early towns of Velasco and Quintana which served as commercial and social centers for the first settlers in the region in the early 19th century. In order to be able to locate and identify sites of importance within the project area and to assess the state of their preservation, the archaeologists spent one month (20 working days) searching out specific structural information from various archival sources. Historic accounts and diaries, Brazoria County Deed Records and other county records provided pieces of the puzzle of the town of Velasco, how it was laid out, who lived there and when, and which lots were built on. Historic maps were obtained from every conceivable source, including the County records, the State Land office, the Texas Archives and the National Archives. The Bexar Archives were searched for information on the Battle of Velasco, and a copy was obtained from this collection of the previously unnoticed description by Lieutenant Colonel Domingo de Ugartechea of his construction of Fort Velasco and of the battle itself (Ugartechea 1832:a-d).

Al1 of this information was compiled to produce working maps of the towns of Velasco and Quintana as they actually were built, and minutely careful measurements and overlays produced the first accurate layout on paper of the towns in reference to the present shorelines today (Fig. 2). These maps were then used to plan the strategy of testing during the next phase of the project. The following sections contain the results of these efforts.

Historical Narrative

The history of the area at the mouth of the Brazos River can be divided into eight periods: (1) the period of Spanish rule (1519-1821) which had little effect on the area; (2) the development years of the Austin colony (1821-1830) when the area was the main entry point for the colonists; (3) the period of growing friction between the colonists and the government of Mexico (1830-1836) when the port became increasingly important, as well as a source of conflict; (4) the Republic of Texas period (1836-1845) when Velasco was briefly the interim capital and then became less important due to the rapid development of Galveston and Houston; (5) the antebellum period (1846-1860) when Velasco and Quintana reached their peaks as sma11 seaside resorts; (6) Civil War and Reconstruction (1861-1874) when the area was a major Civil War coastal defense point, then during Reconstruction, part of a region with a shattered economy; (7) the hurricane years $(1875-1890)$ when the area was devastated 


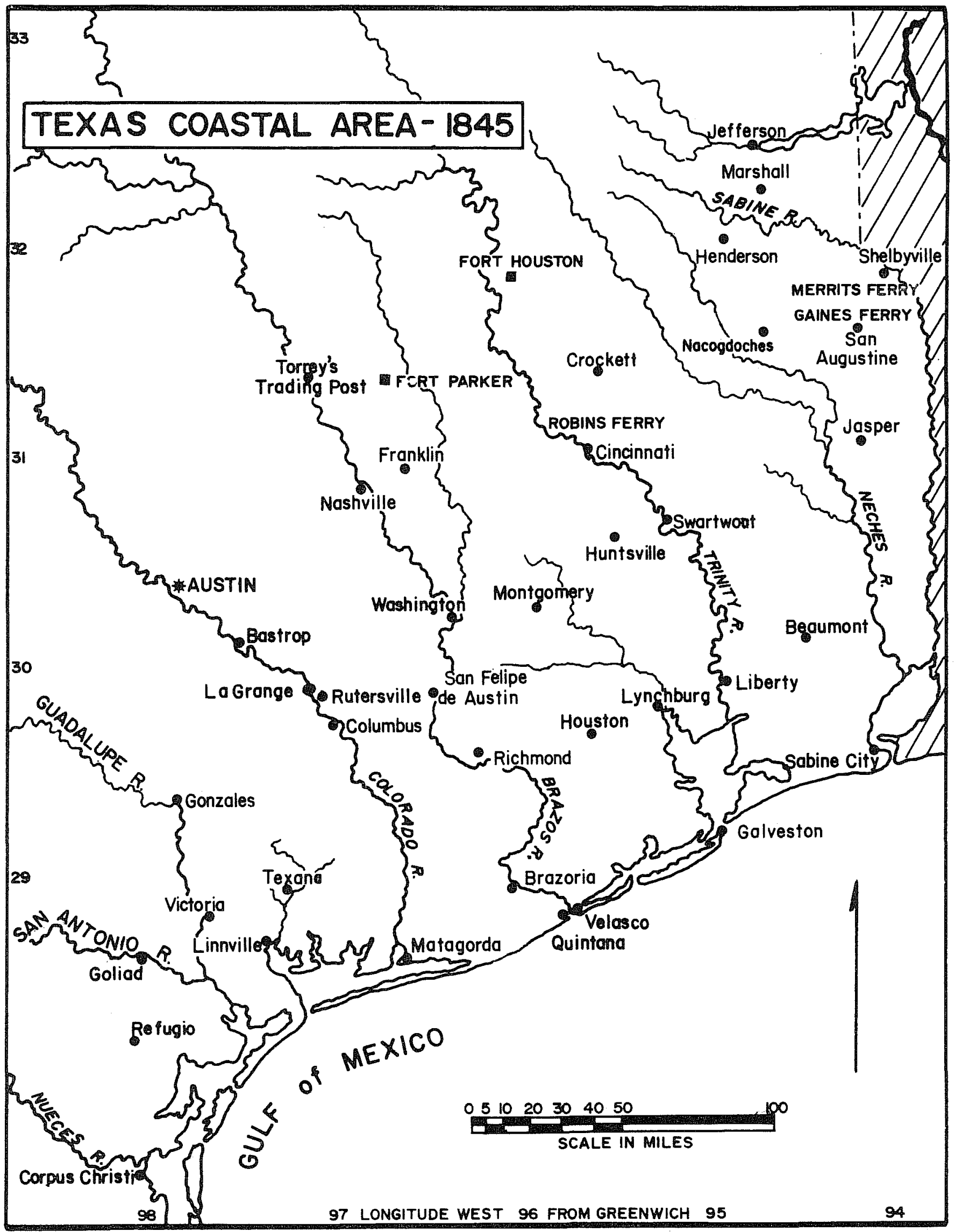

Figure 2. Texas Coastal Area, 1845. 
by two great hurricanes; and (8) the development of modern Brazosport (1890-present) starting with the building of new Velasco upriver.

The Spanish period in Texas is usually considered to begin in 1519 with the mapping of the Gulf Coast from Florida to Vera Cruz by Alonso Alvarez de Pineda; however, Pineda's map did not indicate the mouth of the Brazos River (Farmer 1959:110-114). The next historic event was the shipwreck in 1528 of the survivors of the Narváez expedition, who were trying to reach Mexico from Florida. The account of the shipwreck, by Álvar Núnez Cabeza de Vaca, and of his subsequent life among the Indians and his journey to Mexico, has sparked scholarly controversy over exact geographic locations and routes. Several authorities have published well supported arguments that the Narvaez survivors were stranded east of the mouth of the Brazos River on San Luis Peninsula or Galveston Island. If so, the four strong swimmers sent west along the coast would have been the first Europeans to visit the mouth of the Brazos River (Williams 1979:1-43; Webb 1952 I:261-263). Cabeza de Vaca's account of the coastal Indians (Karankawa or peoples related to the Karankawa tradition) describes them as trusting, friendly and not particularly warlike. These Indians were hunters and gatherers living in small bands who used dugout canoes made from tree trunks. They made tools from marine shells, and made distinctive pottery (and apparently basketry) waterproofed with asphaltum (Hester 1980:48-51; Newcomb 1961:59-81). After Cabeza de Vaca's visit to these Indians, they were not disturbed by Europeans until the expedition of LaSalle in 1685. From that time the actions of the French and Spanish toward them changed their attitude and by the 19th century they had become dangerous foes, requiring no provocation to attack strangers. Looting wrecked ships became a favorite occupation (Newcomb 1961:75-77).

The period of Spanish rule had relatively little impact on the area around the mouth of the Brazos River, although the river with its large flow emptying directly into the Gulf must have been a landmark for mariners. Spanish activity in the region was almost entirely in response to foreign intruders. To counteract French trade and influence among the Indians, the Presidio San Agustin de Ahumada and Mission Nuestra Senora de la Luz were built on the lower Trinity River (Orcoquisac) in 1756 and maintained until 1771. After the cession of Louisiana to Spain by France in 1762, the English and then the Americans became the objects of Spanish distrust (Bolton 1970:328-408). The last years of Spanish Texas were characterized by increasing penetration by foreigners and foreign ideas. After Napoleon's repossession and sale of Louisiana to the United States, Spain was confronted with the restless Anglo-Americans on the Texas border, with fugitive slaves, U.S. deserters and forbidden goods crossing into Spanish territory. Revolution swept Mexico beginning in 1810. By 1816, Galveston Island became a headquarters for revolutionaries and international opportunists, with Aury and Mina in 1816, the Lafitte brothers from 1817 to 1820, Henry Perry in 1817 and Dr. James Long in 1819 (Faulk 1964:113-139), although these activities were disrupted by a hurricane in 1818 (Branda 1976:423). Antonio Martinez, the last Spanish governor of Texas, recognized that the serious lack of 
population was the major cause of the poverty of his province and of his inability to deal with the increasing external pressures. He saw colonization as the solution (Barker 1969:34).

In December 1820, on the eve of Mexico's independence from Spain, Moses Austin appeared in San Antonio seeking permission to settle 300 families on a tract of 200,000 acres on the Colorado River. Governor Martinez ordered him to leave "instantly," but Baron de Bastrop, an influential old friend, interceded and the petition was forwarded to the commandantgeneral of the Eastern Interior Provinces, who approved it in January 1821. Austin received the approval in May but became fatally $i 11$ soon afterward. By the time of his death in June, his son, Stephen Fuller Austin, had begun to carry out his plans. Governor Martinez confirmed Austin as heir to his father's concession and authorized him to introduce equipment duty free through the port of San Bernard (the general area of Matagorda Bay--no specific location was established) which had recently been legalized by the commandant-general (ibid.:24-31; Webb 1952 II:548-549). Austin moved quickly to establish his colony. He named Josiah H. Bell, an associate from Arkansas, to act as Justice of the Peace for the early arrivals to his colony. He purchased a small vessel, the Lively, in New Orleans and made a compact with immigrants to sound the coast of Texas from Galveston to the Guadalupe River, land at the mouth of the Colorado River, build a stockade and plant a corn crop. What the Lively actually did was sail past the mouth of the Brazos River on December 3, 1821, returning and landing cargo and passengers on December 23rd. The Lively then sailed south to make soundings. The disembarked passengers expected it to return, but it did not. It later appeared at New Orleans, took on a cargo and passengers and later was wrecked on Galveston Island. The passengers, stranded at the mouth of the Brazos River, searched in vain for other settlers upstream, and then tried unsuccessively to raise a corn crop. Finally, all but two or three drifted back to the United States (Barker 1969:35-40; Lewis 1899: 224; Creighton 1975: 15-16).

In 1821, the time was auspicious for a colonization effort in Texas. Immigration into the western states had been heavy for several years. The Panic of 1819, in addition to wiping out Moses Austin's remaining fortune in the failure of his St. Louis bank, carried distress and bankruptcy throughout the west. The 1 ifetime savings of many small farmers were wiped out and the letters and newspapers of the period 1820-1825 carry the sad story of debt, court judgements and dispossessions (Barker 1969:80-81; Sturgeon 1943:20). Thus Austin's announcement of generous grants at low prices on easy terms attracted widespread interest. Many families took to the road and many more watched with great interest. Many of those who waited were discouraged by events of 1822-1823-Austin's long absence in Mexico, crop failures, and severe Indian problems. Austin worked hard to correct these problems; by the end of 1824 , the first colony of 300 families was established, and these original settlers received title to the lands. After 1825 there was a large increase in immigration (Barker 1969:80-118). 
The federal law prohibiting colonization, within ten leagues of the sea, did not apply to the first settlers and some of them had located along the coast. Austin called attention to this in a petition in 1826 asking inclusion of the reserved land between the Lavaca River and the San Jacinto River into his first contract. This was approved ("Austin's Coast Colony") with a contract to settle 300 additional families (ibid.:126). One of these early settlers may have been Henry Seaburn, who is said to have come to Quintana before 1820 (Creighton 1975:10). Another was Asa Mitche11, said to have landed at the mouth of the Brazos River in January 1822 (ibid.:19). This conflicts with the accounts of the Lively passengers who found the place deserted in December 1821, and stayed long enough to attempt a crop of corn. Perhaps one or both were Lively passengers. At any rate local tradition has Quintana populated from 1821, Velasco from somewhat later (U.S. Army Corps of Engineers 1979:5-7). On the other hand, Webb (1952 II:424) states Quintana was established by 1836, and Merle Weir (ibid.:835) states that Velasco is one of the oldest towns in Texas where the schooner Lively landed the first of Austin's colonists ". . . and over 25,000 settlers entered through that port from 1821-1835." By 1823, when Josiah H. Bell moved to his plantation at the head of navigation on the Brazos River (Bell's Landing, later to become West Columbia), there was probably some sort of small port at the mouth of the river, quite likely Asa Mitchell's (Webb 1952 I:533). Austin (Barker 1969:118), wrote to his mother and sister on May 4, 1824, of his plan to move them to Texas:

There are two modes of moving to this country. . . Natchitoches... by land. . . two hundred and fifty miles. . the other route is to go to Orleans and thence round by sea to the mouth of the Brazos River, I am undecided which of these two routes will be best. . .

Asa Mitchell was certainly at the mouth of the river at an early date. He came to Texas with his wife and young son and in 1824 received title to about 6820 acres which included the site of Velasco. The March 1826 census lists him as a farmer and stock raiser with a young wife, three children, and eight servants. His brother Eli came to Texas in 1824 and settled near the present site of Velasco (Webb 1952 II:218; Muliins 1959:48).

Initially salt was in short supply in the colony and early settlers went as far as Natchitoches in 1823 to obtain it. At about the same time Jared E. Groce, a weal thy planter who came to Texas in 1821 with some one hundred slaves and fifty covered wagons to settle near present Hempstead (Webb 1952 I:738-739; Smithwick 1900:18-19), took many of his hands to the coast where they dug shallow wells and boiled salt water down, producing "salt enough to last a long time" (Bertleth 1917:364). Mitche11 at least planned to make salt by June 28, 1826, when he wrote Austin that a delinquent debtor had cost him the chance to buy salt kettles in New Orleans, but that he had sugar, coffee and other articles available for immigrants (Creighton 1975:31). Noah Smithwick (1900:19) recalled that about the end of 1827 : 
Elhanan Gibbs came round from the salt works at the mouth of the Brazos River, where Asa Mitche11, the first settler there, had opened a salt factory. . .

By 1825, Austin asked for establishment of a port on Galveston Island, to enable the colony to sell its surplus, particularly cotton and wool. Later, because the island was uninhabited, without timber and subject to inundation, he suggested a port at the mouth of the Brazos River, which would be more convenient for the port officers and colonists. By that time, however, the port of Galveston had been established provisionally, yet no steps were taken to establish a customs house in Texas. Austin saw the importance of establishing trade with Mexican ports and so argued. He also saw the principal business opportunity for the colony was the export of cotton to Europe. In spite of the lack of authorized ports, trade increased, particularly at Bell's Landing. Brazoria was estabiished in 1828 by John Austin (a close friend and possib7y a distant relative of Stephen) as a port and trading center. In 1828, John Austin and James Austin (brother of Stephen and one of the original 300) obtained Mexican registry for a schooner to trade with Matamoros, but the legislation came in an unpleasant package (Barker 1969:180-182; Sturgeon 1943:30-32, 70; Creighton 1975:37; Webb 1952 I:207).

General Manuel de Mier y Teran, who had led a scientific commission preparing for a U.S.-Mexico boundary survey in 1828, developed a grave view of the threat that the United States posed and of the potential for subversion and rebellion among the American colonists. In 1829, he became commandant-general of the Eastern Interior Provinces and authored a plan to save Texas for Mexico. The plan called for the military occupation of Texas, counter-colonization by Mexicans and Europeans, particularly Germans and Swiss, and the development of economic bonds by establishing coastwise trade. This was adopted much as proposed by Teran, as the Law of Apri1 6, 1830. There was one important addition--a complete halt to new immigration from the United States. Austin, although alarmed, loyally supported the law and editorialized to prevent unrest in the Texas Gazette (Barker 1969). Mier y Teran, on the other hand, executed the law so as not to unduly interfere with the Austin and DeWitt colonies (Barker 1969: 256-283; Lukes 1976:161; Bacarisse 1953: 247). An editorial in the Texas Gazette, in May 1830, announced the arrival of "Colonel Fisher, administrator of the port of Galveston." George Fisher, a Hungarian and naturalized Mexican citizen, had been appointed collector of customs in 1829 but did not receive his credentials at that time. Implementing the maritime policy of the new law, George Fisher announced that he would establish a custom house temporarily at the mouth of the Brazos River and place a deputy on Galveston Island. Asa Mitchell seems to have been appointed a boarding officer for the mouth of the Brazos River at about this time. Fisher also announced strict rules for manifests and passports. He was very active for a few months in preparing for the coast trade with Mexico and foresaw an extensive cotton trade with Europe. Then, he and the custom house were suspended by Teran, who thought the admission of foreign vessels to the coastal trade by the Law of Apri7 6, 1830, rendered the customs unnecessary. Fisher in the meantime had accepted a position as 
secretary to the San Felipe ayuntamiento (City Council), where he became embroiled in a controversy and was dismissed (Barker 1969:180-183, 327328; Creighton 1975:58; Webb 1952 II:218). Then, in September 1831, Fisher was again ordered to duty. He was to establish the custom house at Anahuac on Galveston Bay and, as soon as possible, establish stations at Point Bolivar and at the mouth of the Brazos River. In the meantime, he would appoint a deputy for the Brazos River at Brazoria (Barker 1969:328; Sturgeon 1943:53).

Trouble had begun at Anahuac before Fisher arrived. The choice for the military command of this fort was unfortunate. Colonel John Davis Bradburn was irascible, arbitrary and injudicious. Austin (Barker 1969) once characterized him as "incompetent to such a command and half crazy part of the time." In February 1831, Bradburn arrested J. F. Madero, the land commissioner, who was issuing titles to the settlers at Atascosito on the Trinity River. After Madero was released, he established an ayuntamiento at Atascosito which he renamed "most holy Trinity of Liberty"--promptly shortened to "Liberty." Bradburn, who had for months engaged in altercations with the inhabitants, frequently threatening them with arrest, annulled the ayuntamiento in November and established a new one named Anahuac. The same month, Fisher issued a most unfortunate proclamation. Apparently because the arrival of the deputy customs collector for the Brazos River had been delayed, he ordered vessels landing on the Brazos River to obtain clearance from his office at Anahuac (a round trip of approximately one-hundred miles). This and general resentment against the new customs created great discussion in the colony, and in late December 1831, two ships ran past the military guard at the mouth of the river, wounding one of the guards (Barker 1969:322-329; Sturgeon 1943:53; Creighton 1975:52).

A change in the settlement at the mouth of the river had occurred earlier that year. In March 1831, Goodwin B. Cotten and William Chase bought or built a log house (the Brazos Hotel). Cotten, who had published the Louisiana Gazette and the Mobile Gazette, came to Austin's colony in 1829 and published the Texas Gazette, which printed the official matter of the San Felipe ayuntamiento. He sold the Gazette sometime in 1831, but resumed publishing it in December 1831, perhaps after the skirmish at the mouth of the river (Webb 1952 I:419; Creighton 1975:52). An account (Gray 1965:3-5) of this hotel by a visitor of 1831 is puzzling in light of the other houses and the salt works supposed to be at the mouth of the river, but sheds some light on the military force which engaged the vessels:

- . we soon reached the house of Captain Cotton, where a flag was flying. It stands on the bank of the Brazos River, though a mere log house. The owner was formerly editor of a Mexican gazette.

From this place we had an extensive prospect. Although the spot is but little higher than the surface of the water, the country around is so low, and so perfectly flat that the eye embraced an 
extent of many miles toward the interior, as well as up and down the seacoast. . .

Not a dwelling, except the inn, was anywhere in sight.

There were ten or twelve puny, dark complexioned men at Captain Cotton's in uniforms, who I learnt were Mexican soldiers, stationed there to enforce the revenue laws.

Another description of the mouth of the river at about the time of the skirmish is that of Mary Austin Holley (1808-1846:Letter 1836:29), a cousin of Stephen F. Austin:

We came to, before the door of the pilot's house, which parts the stream. The officer of the garrison boarded us to examine our passports, a ceremony the Mexicans are very tenacious of. . . The pilot came on board. He is an American. . . and lives at the point of land formed by the Brazos with the gulf. Here there is a Mexican garrison. . on our right, in front of their palmetto-roofed and windowless barracks, the lazy sentinels were walking their lonely rounds, without excessive martial parade, nor did the unturreted quarters of the commanding officer, show much blazonry of a Spanish Don. There was no tree, no cultivation... Nothing marked civilization, save a fabric for making salt; itself an image of desolation, and the solitary house of the pilot, standing high on piles. .

Two of the results of this skirmish in December 1831, were the anger of Teran and the resignation of Fisher--who later became a Houston businessman, lawyer and city councilman and ultimately the Greek consul at San Francisco at the time of his death in 1873 (Webb 1952 I:600-601). Francisco Duclor, his deputy, assumed his duties but had abandoned them by September 1832 (Barker 1969:329-330, 349; Creighton 1975; Sturgeon 1943:54).

Probably another result of the skirmish was the establishment of the Fort of Velasco. A small detachment was stationed there as early as 1ate 1831. In March 1832, Colone1 Domingo de Ugartechea disembarked at Anahuac and was preparing to go to the mouth of the Brazos with "one cannon of six caliber and 100 infantry." With him was Duclor, the customs collector who expected resistance to the customs (Ugartechea 1832a).

By April 4, Ugartechea had left Anahuac for the mouth of the Brazos River with the infantry, cannon and 17 artillerymen to build the "Fortress of Velasco" (Bradburn 1832). By May 15, the fort was nearly 
complete, but in June, twenty-three men of the garrison had deserted

(Ugartechea 1832b, 1832c). Adele Looscan (1897:283) described the fort:

The fort built by the Mexicans is described by some writers as a log cabin fortress, but according to the recollection of many who remember its construction, it was not built in the log cabin style; logs were used, but in the manner of a stockade. The description by Col. Guy M. Bryan, who saw it when entire, and again when in ruins, is about as follows. The fort was circular in shape and composed of sound drift logs set perpendicularly in two circular rows, the space of several feet between them being filled in with sand. A mound of sand in the center, raised above the pickets, was surrounded with wood to prevent the sand being blown off. On this mound was mounted a nine pound cannon which was on a swivel so as to make a complete circuit guarding the mouth of the river; it could not, however, be depressed so as to protect the immediate vicinity. .

Meanwhile, the troubles at Anahuac had only begun. Bradburn pressed supplies for his troops, used slave labor without compensation and refused to return fugitive slaves, while encouraging revolt among them. He arrested citizens and held them for military trial. Patrick Jack was arrested on some charge and William Barrett Travis, as an attorney attempting to recover fugitive slaves from Bradburn, found himself held. On June 4 , a force started from Brazoria to release the prisoners. It grew to 160 with others ready to join. Ugartechea sent his lieutenant with John Austin to urge the release of the prisoners to civil authorities. Bradburn agreed but when the insurgents withdrew he used the opportunity to strengthen his military position and defied them. The insurgents sent for two cannons at Brazoria and went into camp where they drafted the Turtle Bayou Resolutions, declaring adherence to General Antonio Lopez de Santa Anna, who was leading a liberal revolution. Colonel Jose de las Piedras, the commander at Nacogdoches, marched to Anahuac to restore order and succeeded in getting Bradburn relieved of duty, and the insurgents dispersed, but not in time to prevent bloodshed at Velasco (Barker 1969:333; Creighton 1975:63).

Henry Smith was a major participant in the events which followed. He later became the leader of the "War Party," the provisional governor during the opening phase of the Texas Revolution. At the request of Vice President Lamar, he compiled his reminiscences in 1836 . He recalled that the "fine American Schooner" Brazoria was pressed into service to take the cannons to Anahuac. However, the strong fortress at the mouth of the river, manned by 150 men and equipped with a nine pounder and a four pounder, was in the way. Smith urged his fellow Brazorians to take the fort by surprise. However, since the commander of the force was well liked, a committee was sent to him to try to obtain permission for the vessel to pass the fort (Smith 1911:38). Colonel Domingo de Ugartechea, the commander of Fort Velasco, was a 
career officer who had fought as a cadet with Arredondo (and Santa Anna) at the Medina in 1813. His account, written a few days after the Battle of Velasco lists his force as 64 riflemen and 9 artillerymen. He was visited by a committee of four who asked, in turn, for him to join their party and declare for Santa Anna, for permission for the vessel to pass and for his surrender. Each of these requests he refused (Ugartechea 1832d).

Then Smith's argument to attack the fort prevailed. The plan for the night attack was for a company of 20 men to move into the drift logs on the beach east of the fort and to begin the attack by opening fire at a given time, occupying the attention of the garrison until the Brazoria could drop down abreast the fort. The schooner, armed with "four sixpound carronades and a swivel" and firing improvised rounds of wound-up chain, slugs and bottles filled with buck shot as they were short of round shot, the men on the ship protected by a bulwark of cotton bales, would then open fire. Then, under the cover of darkness John Austin and Henry Smith and their force would move the portable breastworks they had made of "cypress planks ten or twelve feet in length. . . to be set up with props," where they would remain unobserved until daylight "when every shot would te11." Two or more days were spent in preparing, and on the first try the schooner was unable to do its part due to high winds, and the attack was called off until the next night (Smith 1911: 38-41).

Smith recalled a calm, clear starlit night. They crossed the partly dismantled bridge over a bayou above the fort. The schooner came in sight. "As soon as she had cleared the point. . . it was ascertained that the enemy was not asleep" (ibid.). Ugartechea's guards by the river reported the vesse] approaching. He ordered the cannon to fire on the schooner and dispatched his lieutenant with 20 men into the ditch at the base of the fort. He was being fired on by the company in the driftwood at the beach (Ugartechea 1832d). Smith (1911) described the fort as a complete circle enclosing a small area so that it was well manned, with the nine pounder on an elevation "perhaps ten feet above the musketry." As soon as his company opened fire on the fort:

It seemed to ignite instantaneously and flame like a volcano, and from that time until the battle's end the fort seemed to emit one continual blaze of fire directed to all parts.

A11 of the nearby houses had been burned but two, the custom house and a small office. The force with the breastworks gathered near the custom house, and unobserved, moved the breastworks to within 30 paces of the fort "so that the nine pounder could not be depressed enough to bear upon" them. They were to hold their fire, but one excited man fired and gave their position away. In the return fire "the unfortunate man. . . fe11 with many others" (Smith 1911:41-42). Ugartechea "managed to cause greater harm to the enemy behind the stockade." The Brazorians in the trenches yelled "Long Live Santa Anna," while the garrison yelled back 
"Long Live the Mexican Repub7ic. . ." Ugartechea suffered only two casualties during the night, but as daylight came both sides were better able to aim. He ordered his troops in the ditch back into the fort. The battle wound down. Ugartechea's garrison had only 15 guns in working order; they had fired 4600 rounds and had only about 400 left (Ugartechea 1832d). Only a few effective Brazorians were left in the trenches (Smith 1911:43).

Ugartechea's (1832d) version of what then happened is "the enemy was able to hold out until nine in the morning at which time they ran away." He then sent a squad into the enemy stockade which retrieved some 35 guns and reported seeing 11 dead. Then a rainstorm began (Ugartechea ibid.). Smith (1911:43) recalled that about eight o'clock "there came such a heavy storm of wind and rain. . . we were literally drowned out and compelled to retreat." Another Brazorian wrote to a neighbor that day that they would have taken the fort had they not been compelled to withdraw "by a pelting rain such as I have never before experienced" (Bailey 1832). Ugartechea then attended to 19 men who were wounded ( 9 seriously) and then he buried 7 men near the fort; he reported that he believed the enemy had suffered 17 dead and 42 wounded (Ugartechea 1832d). According to Smith (1911:43-44), the garrison 1ost 32 men and a great many more were wounded, while his party lost 7 men, 3 more died later, some were badly wounded and many slightly. Except for 1 dead and 1 wounded on the schooner, his force had borne all the injury and had done a 71 the damage to the enemy.

Under the white flag, Ugartechea met with John Austin. He knew his position was untenable, with no relief possible, and was willing to leave the fort, but only with the honors of war "that is, with arms, munition, equipment and officers ... . in full troop assemblage." On June 29 , a settlement was reached and he had the garrison's belongings and families loaded on the Brazoria which had been badly damaged. Then he gathered his troops, ordered them to fix bayonets, left the fort and marched to the ship (Ugartechea 1832d).

Meanwhile, the revolution supported by the Turtle Bayou Resolutions was going wel1. On June 28, Colonel Jose Antonio Mexia entered Matamoros with his Tiberal army and Colonel Guerra, with the government forces, retired. On July 2, General Teran committed suicide. On July 6, hearing of the troubles in Texas, Mexia and Guerra arranged an armistice so Mexia could go to Texas to prevent loss of the province. Stephen F. Austin accompanied him. Mexia arrived at Velasco July 16 with a strong force, and while in Texas consolidated the province for the liberal cause. San Antonio went over to Santa Anna on August 30 (Barker 1969: 344-346; Creighton 1975:69). The success of the Texans in espousing Santa Anna and the liberal cause encouraged them to air their grievances. The Convention of 1832 was held and resolutions passed calling for exemptions from tariffs, renewed immigration from the United States, land titles for east Texas, government lands to support schools and a separation of Texas from Coahuila. Partly because of opposition from San Antonio, the resolutions were not forwarded. The Convention of 1833 
called for immigration from the United States, better protection from Indians, tariff exemptions and a separate state. A state constitution was offered which provided trial by jury, habeas corpus, freedom of the press and universal suffrage. Austin was sent to Mexico to promote these (Webb 1952 I:404).

When Austin left San Felipe on April 22, he was delayed by rain and high water--and the asiatic cholera had made its dread appearance at the mouth of the Brazos River. One early settler (Menefee 1880) described the rains:

It rained for entire months in 1832 and $1833 .$. .

The most rain that fell at once was about 44 hours

falling--not in showers but one continual pour-

down. You may give a better guess when I tell

you that the Colorado was 8 feet higher than it

was ever known before and the Brazos at San

Felipe 10 feet; all Brazoria was inundated...

the water in some houses three or four feet deep.

Another wrote:

This has been a trying year for Texas. The season has been unusually wet. Owing to this and to the entire loss of at least half the corn and cotton crops on our two principal rivers, the Brazos and the Colorado, by the unprecedented overflow in May. The crop cannot be estimated at more than half what it would have been in a normal year (Sturgeon 1943:37).

The Brazos River crested on June 15 and by June 23 the flood had subsided, "leaving a thick layer of silt which emitted a sourish stench. Mosquitoes bred by the millions" (Creighton 1975:80).

The asiatic cholera was a scourge in Asia before 1830, and then spread along trade routes into Europe. In 1832, it appeared on the U.S. Atlantic coast, and reached New Orleans in October, where it took a tremendous tol1 (Hogan 1975:228). The alarming report of the New Orleans epidemic was sent to the Political Chief of the Department of Bexar, and San Antonio (which escaped the epidemic that year) prepared. Between Apri1 10 and Apri1 12, 1833, out of the approximately twenty settlers at the mouth of the Brazos River, eleven became sick and seven of those died by April 16. The disease spread inland. At Brazoria, about 80 died including John Austin and both of his children, along with William Austin's wife and daughter and the eldest daughter of Henry Austin. Most of the survivors had fled the settlement. Later that year what may have been cholera reached Stephen Austin in Mexico. After his recovery he wrote "there were 43,000 sick here at one time. The deaths I believe have been about 18,000. I have never witnessed such a horrible scene of distress and death" (Haggard 1937:217-230). Two doctors who were at Columbia stated in later life that the cholera was accompanied by yellow fever. The cholera disappeared by the end of October (Hogan 
1975:228). George Bernard Erath (1923:221), an 1832 immigrant from Vienna, described the town and the times of Velasco in Apri1 1833:

Brazoria at this time was perhaps the most prominent shipping point at Texas . . The Brazos was deemed navigable to Bell's Landing ten miles above Brazoria .... After the Battle of Velasco in June 1832, the town of Velasco was laid off near the site of the battle, and it now had about fifty inhabitants. The houses were mere shanties with one unfinished two-story building . . . making of salt from salt wells near the beach . . . was conducted on a very small scale by the two brothers Porter.

In May, while Erath (1923:223) was working for the Porters, he took the bilious fever of the country and hardly knew what was going on for ten days or so. In that time the cholera had also visited the place, and four or five people were dead from it.

In Mexico, December 1833, Austin learned that the law forbidding immigration from the United States had been repealed. Tariff exemptions and improved mail service would be referred to the treasury department. Trial by jury would be recommended to the state government and the federal government would do what it could to prepare Texas for state or territorial government. Austin had accomplished most of what he had set out to do. But on January 3, 1834, he was arrested. He had written to the San Antonio ayuntamiento in 0ctober, urging it to take the lead in establishing a provisional state government. The letter ultimately reached Gomez Farias, Vice President at the time (he and Santa Anna alternated in the two highest offices). Austin would remain imprisoned for a year, and be restricted to the Federal District for an additional seven months (Barker 1969:374-394). The repeal of the ban on United States immigration came at the time of the bank panic of 1833-1834:

The panic... was widespread in its results and reduced thousands of prosperous people to straightened circumstances and many more to absolute poverty .... The distress was greatest in the Atlantic States, and a great many of all walks of 1 ife sought new fields of enterprise in the Middle West-Kentucky, Tennessee and Missouri; in the Northwest, as Ohio, Indiana and Illinois were then designated, and in the Southwest, as Alabama, Mississippi and Louisiana were grouped . . . and Texas just then loomed up as a land of promise, and shared in the general movement (Gray 1965:iii).

Heavy immigration would follow.

At about the time of Austin's arrest, Gomez Farias, believing Texas to be on the verge of secession, dispatched Colonel Juan N. Almonte to 
Texas to make an inspection. The results were published in the "Statistical Report on Texas." Almonte (1925:197-206) reported that the village of Velasco had about 100 persons living under its jurisdiction and he mentions that the military post of Velasco had "for the present been abandoned by our troops." He noted that the Anglo-American did "not like to build large towns." He found the ports enjoying the greatest trade to be Brazoria and Matagorda, and while Brazoria had flourished up to the 1832 cholera epidemic, the opening of the new part of Matagorda and the unhealthy climate "caused it to suffer a great decline." He found Galveston to be the best situated and strongly urged its development as a port and naval base. He noted ". . only by having there an able navy can the slave-trade carried on . . . be stopped." He recorded that the Brazos River was navigable for 250 or $300 \mathrm{miles,}$ and that a small steamboat made trips between San Felipe and the mouth of the Brazos River.

There is a hint that the illegal slave trade referred to by Almonte may have centered on the mouth of the Brazos River. James W. Fannin, Jr. (of the Goliad tragedy), and his family came to Texas in 1834 and settled at Velasco, where his letters affirm that he was a slave trader (Webb 1952 I:582-583). Monroe Edwards came to Texas about 1827 where he associated himself with an unscrupulous New Orleans adventurer smuggling slaves from Cuba to Texas. This yielded him $\$ 50,000$ which he invested in Brazoria County lands. In partnership with Christopher Dart, he bribed officials at the mouth of the Brazos River and smuggled in about 185 slaves in early 1836. Edwards later tried to swindle his partner through forgery, went on to bigger swindles and ultimately died in Sing Sing prison after a severe whipping in 1847 (Webb 1952 I:547).

Also in 1834, Thomas F. McKinney, who in Missouri had been an early trader to Santa Fe, who was one of Austin's 300 , and who began kee1boating and trade with New Orleans about 1830, formed a partnership with Samue1 M. Williams, Austin's secretary and partner (Webb 1952 II:117915). McKinney and Williams started at Brazoria but soon transferred to the new settlement of Quintana with a warehouse sixty feet square. Local tradition is that Quintana was established in the early $1820 \mathrm{~s}$ and named for Andreas Manuel Jose Quintana, 1822-1823 foreign minister under Iturbide. Both McKinney and Williams 1ived at Quintana. They estabTished a line of three small steam vessels carrying merchandise and supplies upriver and export products bound for New Orleans downriver (Nichols 1953:198-199). The firm aided the provisional government during the revolution by issuing notes to circulate as money and by the use of the three vessels, the Laura, the yellow Stone, and the Lafitte. On their private credit they were able to advance the Republic of Texas more than $\$ 150,000$. It was the largest commission-merchant firm in early Texas and controlled much of the cotton trade. In 1837, the firm began banking in Quintana and by 1837 (or 1838) the firm moved to Galveston and became increasingly active in lands, banking and industrial and town promotion--at one time owned one fifth of the city of Galveston (Webb 1952 II:118; Nichols 1953:199-204; Hogan 1975:102). On Apri1 22, 1835, Samuel A. Maverick, on a land buying trip to Texas, went 
ashore at Velasco and noted that Velasco had eight or ten families and Quintana on the west side had two or three families and the Mckinney and Williams wholesale store (Green 1952:25).

Almonte's (1925) Statistical Report testifies to the generally peaceful conditions in Texas in 1834. However, in Coahuila a small civil war erupted over control and location of the government. This continued into 1835 and in March, laws were passed which allowed gigantic land speculation. Several prominent Texans were involved including Samuel $M$. Williams, and there was considerable disgust in Texas. At the same time Santa Anna was consolidating his power; he placed himself at the head of the army and crushed an insurrection in Zacatecas. In May, the Mexican congress essentially overthrew the Constitution. In the meantime a military structure was imposed on Texas. Martin Perfecto de Cos, brother-in-law of Santa Anna, was commandant of the Eastern Interior Provinces, and he appointed Colonel Domingo de Ugartechea commandant for Texas. In January 1835, Captain Antonio Tenorio, his garrison, and a customs collector (with a deputy for the Brazos River) arrived at Anahuac, and history repeated itself. The news that citizens had been arrested at Anahuac and that General Cos had arrested Governor Viesca reached San Felipe at about the same time, and letters a courier was carrying to Tenorio were siezed. One was from cos promising heavy reinforcements and another from Ugartechea saying the troops which had crushed Zacatecas were at Saltillo on the way to Texas. Considerable unrest followed, and on June 29, at Anahuac, William B. Travis, with twenty-five men and a cannon, demanded and received Tenorio's surrender. This act and others by the more rebellious citizens were widely condemned, and many peace resolutions were passed. However, Cos demanded the arrest of Travis and several others including some of the speculators, such as Williams. This and Cos' intention of occupying San Antonio reversed many minds, and on August 20 a committee representing a deeply troubled citizenry called for a Consultation to meet October 15 at Washington on the Brazos River (Barker 1969:395-409). After his long imprisonment, Austin arrived at Velasco on September 1 , with his mind clear as to what course Texas should take. His "peace party" had opposed the Consultation, but Austin endorsed it and worked hard to prepare for it--and for war. He had reached the decision that Texas must be independent. The seven month war began with a skirmish at Gonzales on October 2 . On October 11, Austin was elected commander-in-chief, and the next day the march on San Antonio began. General Cos had landed at Copano in September and entered San Antonio on October 7. At San Antonio, Austin's army went through a period of confusion and indecision. On November 3, the Consultation met and established a provisional state government. Austin was sent to the United States to obtain aid. Volunteers from the United States soon began arriving in Texas and would continue for many months. On December 5, the assault on San Antonio began. On December 10, Cos capitulated and marched $h$ is forces south. Then a long series of reverses began. On January 20, 1836, Fannin sailed from Velasco to Copano Bay with some 450 men and camped at Goliad. Dr. Grant with a smaller force moved to the San Patricio area. In the meanwhile, Santa Anna was moving north with a large force. He laid siege to the small force of Travis in 
San Antonio on February 23 and stormed "Fortress Alamo" on March 6. General Urrea's cavalry wiped out the San Patricio force in late February and early March, and Fannin's force at Goliad in late March. Then Santa Anna divided his force into five divisions and proceeded east, burning everything in their path. The ensuing panic, known as the "Runaway Scrape" was at its height when the word came of Houston's victory at San Jacinto on Apri1 21 and the capture of Santa Anna (Barker 1969:410-426; Fehrenbach 1968:191-233).

Meanwhile Velasco had become a strong point in the Texas naval defense and would continue in this role for several months, which may explain the later selection of Velasco as the interim capital. Mckinney and Williams (Jenkins 1973 II: 211-212; Webb 1952 I:403) wrote to Gail Borden and R. R. Royall at the Consultation which met at San Felipe on October 16 reporting that the Fort of Velasco was able to repel any sea force which might wish to land there, being armed by "a most superior long 18 pounder," some small guns and sufficient ammunition. They also reported the arrival of volunteers from the United States and supplies being sent to the army, and requested information on what supplies were needed. On the 29th they again wrote Royal1 ("President of the Council of all Texas"), reporting a Mexican cruiser off Quintana and an exchange of fire. They would definitely take the vessel, but wished to point out that the United States citizens among them risked piracy charges. They warned the Consultation:

The Mexican Government will doubtless send a maritime force to annoy our coast and cut off our supplies and intercourse with the United States, if they can succeed almost total ruin will be the consequence. . Now what are we to do to protect ourselves . . . the most active measures are needed to counteract the advantage. . . Santa Anna has over us by having armed vessels already on the Gulf and some of them actualiy upon us . . Would it not be well for the Consultation. . to issue commissions for armed vessels... and in three weeks or four... our coast will be cleared.

United States officers were with them and would assist them in taking the Mexican vessel and would await the commissions (Jenkins 1973 II:260261). The General Council (charged with managing Texas during the provisional government) met on November 14, and on the next day, passed bills to purchase four schooners, organize a Texas Navy, and issue letters of marque to privateers (Webb 1952 I:677-678; I I:749).

The Republic of Texas began with the Convention of 1836, which met on March 1 at Washington on the Brazos River, declared independence on March 2, wrote a constitution, elected an interim government (David G. Burnet, president; Lorenzo de Zavala, vice-president), and with the report of the approaching Mexican army, adjourned in haste on March 17. The interim government moved to Harrisburg, then, barely escaping Santa Anna, who burned Harrisburg on Apri1 16, to Galveston and then to 
Velasco. Afture his capture on April 21, Santa Anna was taken from Galveston to Velasco, which would serve as the capital of the Republic until establishment of the permanent government at Columbia in october. Santa Anna signed the Treaty of Velasco there on May 14. The public treaty provided for cessation of hostilities, restoration of property and retirement of the Mexican forces beyond the Rio Grande. Included in a secret treaty was Santa Anna's pledge to use his influence to obtain recognition of Texas independence in return for his return to Mexico. On June 1, de Zavala and Bailey Hardeman were ready, as commissioners, to embark with Santa Anna for Mexico on the Invinceable. Opposition to allowing Santa Anna's departure was ignited into a mutiny by a newly arrived force of volunteers from the United States led by General Thomas Jefferson Green. Burnet was forced to transfer his distinguished prisoner to Quintana. Santa Anna remained a prisoner under deplorable conditions until late in the year. The government was powerless to enforce the Treaty of Velasco, and as Santa Anna remained a prisoner, Mexico had every reason to repudiate it (Friend 1969:70-72; Fehrenbach 1968:243244; Pierce 1969:165).

The period of Velasco as the capital of the Republic must have given the economy of the 1ittle town a boost. Mary Austin Holley (1836:121-122), in her book promoting Texas, described the mouth of the Brazos River in rosy terms:

Velasco... is celebrated for its salt works which are very notable. It is a small town but is well situated, and is in a flourishing state. A collector of customs resides there. Velasco is the resort, in summer, of great numbers of visitors from the north of the colony, who come to enjoy the delightful sea-breezes, sea-bathing and the comforts with which they are everywhere surrounded. Excellent accommodations can always be obtained at boarding houses which, among other attractions, are always furnished with supplies of oysters and fish of the first quality. A Mexican garrison was formerly stationed at Velasco; at present it is the rendezvous of the patriot troops . . Quintana is a town in embryo containing a proprietor's house belonging to Mr. McKinney and a large warehouse . .

The patriot troops referred to by Mrs. Holley seem to have been concentrated at Velasco during this period. Quartermaster-General Almanzon Houston opened his office there in July 1836 and divided his time between Velasco and Quintana. Fort Velasco was probably well manned during the time Velasco was the seat of government, but probably only a sma11 company was there afterward. There seems to have been a mutiny and one or more duels (Pierce 1969:164-166). A soldier stationed there in 1837 recalled a Mexican invasion attempt, a mutiny, and a fire which burned the barracks to the ground (Seele 1979:99, 102-103). 
During the period of the Republic, speculation in lands and town building and promotion were rampant. John A. Wharton, William H. Wharton, Branch T. Archer and General Thomas Jefferson Green were the guiding lights of Velasco (Hogan 1975:89). In 1837, a great hurricane swept eastward along the Texas coast, wrecking nearly every vessel. It blew away all the houses on Galveston Island and sent flood waters fifteen or twenty miles inland. James Morgan (Bass and Brunson 1978:57) wrote encouragingly to Samuel Swartwout, who had purchased town lots in Velasco:
Velasco, I think was benefited by the great gale
in as much as there was not a general overflowing
of this place and there was at Galveston or nearly
so--It has strengthened confidence in the friends
of Velasco and from the local advantages that
place promises, it must go ahead--I am strongly
inclined to the opinion that it will be the seat
of Govt. at some day.

Morgan came to Texas in 1830 and opened a store at Anahuac. He 1ater developed the area now known as Morgan's Point. During the revolution, like Mckinney and Williams, he furnished the government with merchandise and the use of his ships, and, as commandant, he fortified Galveston Island. Later he became the "father of the Houston Ship Channe1." Swartwout, collector of the Port of New York (where he had paid repair bills for two Texas naval vesse1s) was involved in business with Morgan. Two months later Morgan (ibid.:65) was less optimistic when he wrote:

Velasco is going ahead slowly : All Texas
wants to settle on the Bays $: \dot{i}$ and increasing
in value and changing hands daily.

General Thomas Jefferson Green seems to have been the most visible Velasco citizen at this time. He was a planter in Florida where he organized the Texas Land Company. He came to Texas in 1835 with capital to acquire Tand. Instead, he was commissioned brigadier general and returned to the United States to raise volunteers. A Bexar County representative in 1836, he was elected to the State Senate in 1837, but his seat was declared vacant soon after the session opened. He later took part in the Mier expedition, was imprisoned in Mexico, and went to California in 1849 (Webb 1952 I:727-728).

Horse racing was a universal American sport during this period, and Velasco was one of the chief racing centers, with large purses and heavy wagering. General Green:

- . was a moving spirit among several prominent men who were officers of the New Market course at Velasco .. General Green . . had been the most successful operator on the Texas tracks. He was president of the Velasco club in 1839, and the owner of a string of horses which ran successfully both in Texas and the United States (Hogan 1975: 130-131). 
The racing meets were festive occasions. Mary Austin Holley (1808-1846, Letter February 21, 1838) wrote to her daughter Mrs. Brand from Peach Point in early 1838:

There is to be a great ball at Velasco tomorrow . .

Being the period of the races . . . Everything available for dresses in Texas has been bought up for the occasion. Confectionary and ornaments are to be brought by the Columbia from New Orleans.

Other amenities were established during this period, with the Archer House in Velasco offering hotel accommodations. In Quintana, Mrs. Gibbs opened a boarding school for young ladies, which offered chemistry, philosophy, botany--even calisthenics (Hogan 1975:107, 145). Some competition between Quintana and Velasco is indicated in a letter (Gulick and E11jot 1921:82) of Mrs. Holley's cousin, James F. Perry (brother-inlaw of Stephen F. Austin, executor of his estate after his death on December 27, 1836, and owner of Peach Point Plantation where he was buried). He wrote to President Lamar on January 3, 1839 that he had heard the custom house had been moved from Quintana to Velasco, and he suggested that Velasco was "not the best place. . . vessels cannot lie there with safety in rough weather." Apparently, Thomas F. Mckinney had donated two lots for the new custom house (ibid.). Perry may have been concerned over Austin family interests in Quintana. McKinney and Williams by then were in booming Galveston, where they established trade connections for English goods in return for Texas cotton (Nichols 1953:205).

William C. Sheridan (Pratt 1954:18-20), an Englishman who visited and described the Galveston of that period, also recorded his impressions of Velasco in January 1840:

Between 20 and 30 irregularly built huts and houses---situated---on a low sandy beach wh soon merges into a flat shrubless, prairie extending as far as the eye can reach. There are a few houses on the left side of the river... but the greater part locate on the right . . . The shore. . is covered for miles--even almost unto Galveston . . with the trunks of trees, some of enormous size and principally (cotton wood). . . This circumstance... is of the greatest service to the inhabitants . . . supplying them with fuel and timber-once or twice a year a party journey up the river and cut down a large quantity . . . float to the Gulf. . strong current from the East wh meeting with the flowing waters of the Brazos, hauls up the wooden freight upon the Beach.

Sheridan noted some of the more prominent citizens, Mr. Thompson, the harbor-master and pilot, General Green, John Sharp, the United States Consular Agent William T. Austin (brother-in-law of John Austin and 
customs collector), and Reuben M. Potter, his deputy, whose long and interesting career included work as translator, interpreter, quartermaster and historian (Webb 1952 II:401). Also mentioned was Mrs. Seffield, the dancing mistress. He estimated the population at about 300 and described the armament (from the fort?) in front of the courthouse--an 01d brass 18 pounder and three smaller guns. Game was described as being plentiful. "Ducks, snipes, geese, turkeys and all." Milk was not available because the "cows of Velasco. . . are driven into the woods to recruit their energies with the young grass." $\mathrm{He}$ described the food eaten as pork, turkey, oysters, and catfish for breakfast. One dinner was fat pork, wild turkey, fried liver, turnips, sweet potatoes, pickles, peach jam and other "dainties." Sheridan was alarmed that the natives ate mainly with the knife, and picked their teeth with the pocket knife (Pratt 1954:12-22).

The early 1840s seem to have been hard times in Velasco. The Panic of 1837 1eft the United States in a depression in 1840, and Europe was having problems also. Cotton prices were depressed. Money was scarce and business in Texas stagnated. Barter and exchange became the mode of business with a cow and a calf representing ten dollars. Partial failure of the cotton crops occurred in 1842 and 1843 (Hogan 1975:9495), Galveston was hit by a hurricane in 1842 with $\$ 50,000$ damage (Branda 1976:424), and there was flooding of the Brazos River in late 1843 (Curlee 1923:97). James Morgan (Bass and Brunson 1978:184) wrote Swartwout of the situation in June 1842:

We can in Texas nearly one and all exclaim with Iago, "he who steals my purse steals trash." Why if you could only see some of the great men of Texas... If you could only know the fact of their situation... their real poverty and distress... when Sam Houston never had enough money within the last 2 years to purchase him a suit of clothes... you can have no idea of the scarcity of money in this country.

By the period between annexation and the Civil War, Velasco and its sister city across the river seems to have reached their peak, perhaps even before the hurricane of 1854 which did heavy damage to both towns (Branda 1976:424). Merle Weir (Webb 1952 II:835) described the antebellum towns:

They were summer resorts for the weal thy plantation families for the region. A seminary for young ladies and one for young men taught by Oxford graduates were estabijished. Comfortable hotels were built to accommodate the visitors and the patrons of the race track located a short distance up the river.

Some insight into these "wealthy plantation families" can be gained from 1850 statistics. Brazoria County had a white population of 1329 , the colored population was 3512 , the highest proportion and second highest 
total of al1 the Texas counties. It was by far the largest producer of sugar with nearly five million pounds and fourth leading cotton producer with 3500 bales (01msted 1978:473-479).

Traditional Velasco history holds that the completion of the Galveston Brazos Navigation Company canal started the decline of Velasco, diverting its trade to Galveston (ibid.). It is more likely that the decline in the importance of Velasco as a port began with the relocation of McKinney and Williams to Galveston and the rapid growth of that port and city (to more than 4000 in 1850, the state's leading city). Mrs. Holley, who made her first trip to the Austin colony in 1831 by way of the Brazos River, spent a day and a half waiting for a favorable tide to cross the troublesome bar, and another day and a half traveling the thirty miles upriver (fifteen by land). On her next trip, she preferred to land at Galveston, bustling in spite of the recent (1837) hurricane, travel by steamer to Houston and travel overland to Brazoria. By that time the Brazos River planters were hauling their product to Houston, then by water to Galveston (Sibley 1967:33-34). The Galveston Brazos Navigation Company was chartered in 1850 to construct a canal between Galveston Bay and the Brazos River. By 1855, the four and a half mile canal plus thirty miles of waterway were completed. The canal was fifty feet wide and three and a half feet deep and could accommodate small steam vesse1s. The canal enjoyed some initial success and probably had a negative impact on the port of Velasco, but the cost of keeping the canal open exceeded profits and the developing Houston rail network soon overshadowed both (Forne11 1961:29-30).

Secession sentiment was strong in Texas at the beginning of 1861 , particularly in the plantation country along the Brazos River. The Secession Convention met in late January and voted to secede, which was ratified by popular vote on February 23. In San Antonio, Major General David E. Twiggs surrendered the Department of Texas (2700 men and $\$ 3,000,000$ in material) to a committee of public safety composed of Samuel A. Maverick, Thomas J. Devine and P. N. Luckett. General Twiggs is reported to have left for New Orleans the same day and was commissioned major general in the Confederacy in May (Webb 1952 II:812; Johnson and Bue 1 1884:33-36; Fehrenbach 1968:352). In February, Colone1 John S. Ford led an expedition to capture the large concentration of federal equipment at Brazos Santiago and Fort Brown, where he captured heavy guns which would be used later in coastal defense--some 32 guns and 7300 rounds of ammunition. Six more cannons were taken in March at Fort Clark (Barr 1961: 3-4). The federal forces, paroled, marched to the coast to be taken to the United States by the sea (among the parolees Captain Reuben M. Potter, the 1840 deputy collector at Velasco). On April 17, the confederate policy of parole was reversed; the federal transport Star of the West (which had been fired on at Fort Sumter in January) was seized and the remaining federal forces were held as prisoners (Malsch 1977: 147-151). On Apri1 19, President Lincoln established the naval blockade of the Confederacy. Texas, with some 400 miles of beaches and harbors, presented a formidable challenge for both the blockaders and the defenders. The initial blockading force was 42 ships, but there was almost no coastal defense. There were no masonry 
forts, few heavy cannons (none mounted) and the prescribed method of coastal warfare was the artillery duel. Within this concept, earthwork defenses soon became preferred (Barr 1961: 1). In June 1861, Captain Walter H. Stevens, assisting in the fortification of Galveston, submitted a plan of coastal defenses which included a 24-pounder at the mouth of the Brazos River. In July, the federal warship South Carolina appeared off Galveston. In September, Colonel Joseph Bates was appointed commander of the Fourth Texas Volunteer Regiment to defend the coast between San Luis Pass and Caney Creek. Companies B and F served the heavy guns at the mouth of the Brazos River.

Early in the war, General Hebert, commander of the Confederate forces in Texas, pulled back the artillery to the mainland (at least to Galveston) (ibid.:3-8). In Galveston "the Texas and Confederate military authorities decided to abandon the Island to the Yankees . . . and insisted that the island city should be burned to the ground and the wells filled with ashes" which the islanders defied (Fornel1 1961:298). In January 1862, federal ships engaged the Velasco shore batteries to test their strength and range (Barr 1961:9; Creighton 1975:235). No other engagements seem to have occurred at velasco until midsummer, when action took place on July 4 and on August 11 (Creighton 1975:238). Bates defenses, which appear to have been strengthened, beat off an attack (Barr 1961:9). The surrender of Galveston to an insignificant federal force in October aroused sufficient furor to have General Hebert replaced by General John B. Magruder "wishing to regain a military reputation he had lost in Virginia." He hastily organized a force and recaptured the Island on January 1, 1863 (Forne 11 1961:298; Webb 1952 II:131). On September 23, 1863, Brigadier General P. N. Luckett, who had received the surrender at San Antonio inspected the defenses at the mouth of the Brazos River. These included a fort on the west bank a mile above Quintana, one 4 miles upstream from old Velasco on the east bank, and one at the drawbridge across the canal (Looscan 1897:284). He found Colonel Bates to be effective and in need of 200 cavalry to augment his force of 300 , in order to be able to defend against a sea attack or one by land, but not both. Because of the great wealth of the region and because of the anxiety of the inhabitants for their property (primarily slaves) Luckett recommended the reinforcement. The fort on the west bank of the river had three guns in position--a 24-pounder, an 8-inch howitzer, and a 32-pounder sent over from Sabine Pass, possibly from one of the federal warships captured in the battle there earlier that month. The fort on the east bank had not been completed. There was an 18-pounder mounted on the right bastion. A 32-pounder also from Sabine Pass was put in position "but the platform being too small, at the first discharge the gun flew off." A larger platform had been built. The engineer reported it would take 200 men 15 days to complete the fort using slave labor from the vicinity. On the $22 n d$, a vessel fleeing "from the three masted schooner of the enemy which has been cruising for some time past off the mouth of the Brazos" was intentionally run aground and burned. On the 24 th, a vessel with $\$ 9000$ in merchandise ran the blockade. There were eleven vessels in port, one with import goods, most of the rest with cotton. The vessel and the 
surrounding bridges were to be burned if jeopardized. General Luckett found the discipline good but the garrison suffering from the diet of cornmeal and the brackish water, owing to the drought. Also at Velasco was a battery in good order except the horses (which had returned from a hard trip into Louisiana), and a well-mounted and we11-armed company of State troops, with another company to arrive in a few days. The hospital was small and in poor condition (United States Department of War I-XXVI-I I :263-264).

From 1863 to the end of the war large numbers of troops were stationed on Galveston Island and were an economic asset to the city. This also appears to have been the case at Velasco (Fornel1 1961:299; Creighton 1975:244-245). Also the sea-faring Galvestonians and their blockaderunner associates developed techniques to outwit the federal war vessels, and a thriving trade developed between Galveston and Europe and the West Indies, particularly in late 1864 and 1865, after the ports east of the Mississippi had been closed; this was also probably true to a lesser extent at Velasco (Forne11 1961:299; Barr 1961:29). According to local informants, Confederate troops pulled up for firewood the last remaining traces of old Fort Velasco (Looscan 1897:283).

After the surrender of Lee at Appomatox in April 1865, the TransMississippi Department of the Confederacy tried desperately to negotiate more favorable terms. The order to evacuate Galveston in order to concentrate the forces at Houston triggered the breakup of the army. In groups of various sizes, they headed for home, for Mexico (including the Governor, General Magruder and General Luckett), and for elsewhere. Lawlessness prevailed and the occupying forces, when they arrived, were too few to be able to impose order. The state was placed under military rule. The planter class was virtually wiped out. More than 200,000 former slaves were suddenly free. Cotton prices dropped, land values collapsed and estates were lost. The new elite were mercantile and the term "planter" disappeared from the Texas vocabulary. Taxes were high but the treasury was empty. Corruption was widespread and a widelyhated state police was established. This "reconstruction" ended in Texas on January 19, 1874 (Fehrenbach 1968:393-432). To add to the other problems of Reconstruction, in 1867 a yellow fever epidemic was widespread in Texas, taking a heavy toll in Houston, Galveston and Indianola and reaching far inland to places that had not been seriously affected before (Ma1sch 1977:192-193). To add to the misery, the same year a hurricane struck south of Galveston, with $\$ 1,000,000$ in damages at Galveston (Branda 1976:424). With the arrival of summer, the next year, the Fifth Military District established quarantine stations on the Gulf Coast to inspect all incoming ships and passengers. In the meantime, efforts were being made to bolster the economy at the mouth of the Brazos River. In 1872, it was proposed to construct an artificial harbor, to be the terminus of the Columbia Tap Railroad (to connect with the rail from Houston to Columbia). Apparently, lack of financing ended the project (Malsch 1977:225).

After Reconstruction, with the growth of Texas ports and the increased population on the coast, Texas would have to come to grips with the 
forces of nature. In 1875, a hurricane passed over Cuba, brushed the Florida Keys, and turned west, blocked by a high pressure area over the United States. It passed south of Galveston from September 15-18 doing great damage and the water level was the highest known to that time. The eye passed over or near Indianola at the mouth of Matagorda Bay in the early morning of the 17th, destroying three-fourths of the buildings in that city and wrecking most of the rest--with 176 dead (Malsch 1977: 228-248). At Velasco, it "destroyed even the records of the town" (Webb 1952 II:835). At Quintana, according to Humphries (1933), 175 people took refuge in the Seaburn home, then retreated to the schooner Verbena and rode out the storm. The Signal Corps called it the most severe hurricane up to that time and apparently, the hurricane warning flag of today was a result of the storm (Malsch 1977:251-253). The warning flag did not help in 1886. On August 19, when the Indianola weather observer received warning, the fast moving hurricane had already struck. He died at his duty. This storm, with higher winds than in 1875, finished Indianola, destroying or damaging every building. The hurricane left a trail of wind damage all the way to San Antonio, where the wind was recorded at 72 miles per hour when the roof of the weather station building was torn off and the anemometer wrecked (ibid.:262-266). The 1886 storm appears to have finished old Velasco as well. as Indianola.

In 1891, the modern period of the mouth of the Brazos River began when Velasco was moved away from it. The same company, apparently, (Texas Land and Immigration Company) which had founded Angleton the previous year founded the new town four miles upriver from old Velasco. At about the same time the Velasco Terminal Railway was chartered. Twenty miles of track were laid to the International and Great Northern at Chenango Junction. This railway went into receivership when plans for a deepwater port failed, but the Seaboard and Gulf Steamship Company was later established to operate with the rail line. In 1893, the San Antonio and Gulf Shore Railway was chartered to run from San Antonio to Velasco and 29 miles of track were laid but this also failed (Webb 1952 I:50, 848, 849; II:543, 836). Weather plagued the new town as it had the old. In summer 1899, the record flood of the Brazos River occurred, and in September of the next year 75 percent of the houses in Velasco (which had grown to 3000) were destroyed by the "Great Galveston Storm" which killed 6000 to 8000 at Galveston. Eight died at Velasco (Webb 1952 I I:836; Mason 1972:221; Creighton 1975:318). In Ju1y 1909, Velasco had its own hurricane with half the town destroyed, 41 dead and damage of $\$ 2,000,000$ (Texas Almanac 1974:555).

Then in 1912, across the river, Freeport was founded by the Townsite Company, New York capitalists interested in developing the region's sulfur deposits. The next year the 200-mile section of the Gulf Intracoastal Waterway below Galveston was opened. Later the $0 i 1$ resources of the region were developed. In 1929, a river diversion channel was dredged leaving the old channel as a tidal basin port (Webb 1952 I:646, 746). In 1939, Dow Magnesium Corporation built their plant to extract magnesium from seawater, and in 1942, coastal defenses were built to protect that strategic plant. A17 the factors were then present for the making of today's vital Brazosport. The area at the mouth of the old 
river channel was not abandoned. Quintana remained as a small village, and soon after the establishment of the new Velasco, the community of Surfside began to occupy the lower part of the site of old Velasco, as a seaside community paralleling the Gulf beach. The floods and hurricanes continued, with great floods in 1913 and 1915. During the second great Galveston hurricane in 1915, fourteen lives were lost at the Life Saving (Coast Guard) Station at Surfside Beach, and the station destroyed, to be rebuilt in 1917 (Creighton 1975:328-331). Other hurricanes followed: 1932, 1941, 1949, and 1961 (Texas Almanac 1974:555-557) and sti11 others to come will periodically visit the land at the mouth of the Brazos River. But the port at the mouth of the river had adjusted to the problem of hurricanes by moving the port away from the river's mouth, and to the problem of floods by moving the river away from the port, leaving the small communities at the old mouth of the Brazos River to their cycle of destruction and renewal.

\section{Structural Research}

Methodology

The principal goals of this project were to determine if any portions survived of the Mexican Fort Velasco and the original town of Velasco. A secondary purpose was to survey a portion of the townsite of Quintana for original structural traces.

In order to test for these sites, reasonable hypotheses for their locations were necessary. Such a set of hypothetical locations was compiled by historical research prior to the beginning of excavation.

It was quickly discovered that although two quite similar plats of the town plans of Velasco and Quintana existed, their locations on the present ground was unknown, since no apparent reference points survived to tie them down to specific positions. Since all subsequent work depended on a relatively accurate replotting of the plan of Velasco on the ground, this problem was approached first.

The first necessity was to overlay the most dependable town plat of Velasco and the 1852/58 United States Coastal Survey (USCS) plan of the town, which showed structures and fences, but gave no hint of where on the plan of the town these structures stood.

In order to do this, a deed-transfers density plot was worked up from an examination of the deed records: a plan of the town was drawn, and lots were shaded in each time they were bought and sold (see Fig. 3). Lots which were bought or sold more often were therefore shaded much darker than those which were bought or sold more rarely. The deed density map showed an obvious similarity to the 1858 USCS map, and strongly argued for the identification of the town square visible on the USCS map as Monument Square on the town plat. The identification of this square and the associated streets was confirmed by a peculiarity of street alignment at the corner of Monument Square. What would appear to be Second Street 


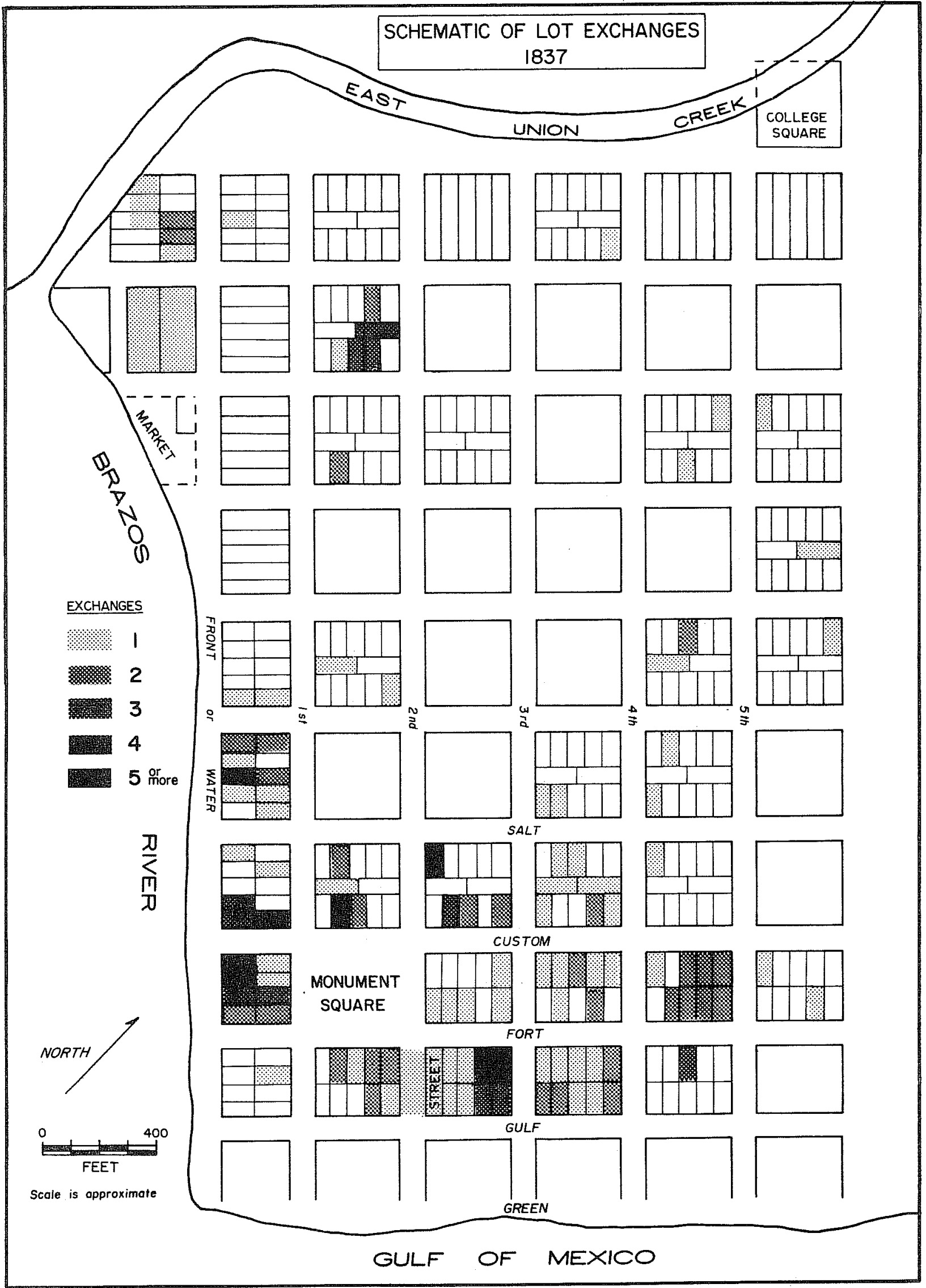

Figure 3. Schematic of Lot Exchanges in 1837. 
is offset towards the northeast by approximately its own width on the USCS map, and a structure is so placed on the adjoining lot to the southwest that it overlaps the line where the street apparently should have gone. Assuming that our placement of the streets and Monument Square were correct, this structure would be on lots 4, 5, 6, and 7 of block 13. In Volume $C$, page 368 of the Brazoria County Deed Records, lots $4,5,6$, and 7 of block 13 were the site of the Archer House Hotel. The deed states that lots 1 and 10 of block 29 (the two lots immediately across Second Street to the northeast) are "being given up by the proprietors of said (tract) as a continuation of said Second Street" because of "the said Archer House having been built in that part of said street by Mistake." In other words, Second Street was offset northeastward into lots 1 and 10 of block 29 to go around the Archer House Hote1, which was built in the line of the street. This serves as a positive proof of our identification of the square, streets, and blocks.

After the location of actual structures in 1858 onto the town plan, the next step was to locate the town plan with respect to the present topography. Deed and map research told us that the sizes and alignments of the various land grants in the area were inconsistent through time. The Asa Mitchel1 survey line, for example, had at least four different locations for its northeastern corner, with variations of several hundred feet between the locations. This corner, if it could be located with certainty, would have been critical for the accurate location of the Velasco town plan, but such a difficulty meant that the location of the town plat on the ground by using the position of the Asa Mitchell grant lines was not possible. It was decided that the best method would be through the use of a combination of landmarks common to the various maps of the area made over the years, and the location of specific properties whose position in the original town plan were known.

By a process of rescaling the maps of various periods in the life of the town, the overlay map shown in Figure 2 was produced. Using an early version of this map, our excavation units were placed on or near the locations of buildings where these were accessible. Many building sites were in swamps, under roads, or in the line of drainage bulldozing, and therefore could not be investigated. Excavation units were placed in areas considered to have the greatest chance of locating structural traces.

Structural History: Compilation

After a relatively good location of the town plan on the ground was achieved, a structural history of the site was compiled from the general historical narrative and specific details found in various records. This was necessary for several reasons: (1) to be able to recognize the various structures sought after, if they were found; (2) to be able to recognize the stratigraphic patterns in the ground associated with the changes through time in culture, plan, and use of the structures located, if any; (3) to have some idea of how to correct our assumptions about location and change through time when difficulties in location and 
stratigraphy were encountered; and (4) to minimize our disturbance of the archaeological record of the site while still acquiring sufficient information to meet the goals of the project. Given a good research preparation, a far smaller amount of information retrieval from the ground is usually enough to recognize a structure or time period than is the case when little is known about a site.

The following series of maps (see also Table 1) illustrate the growth and decline of the towns of Velasco and Quintana during the 150 years since the establishment of the Mexican customs house at the mouth of the river:

Figure 4; Velasco and Quintana area, 1832: Until 1831, the mouth of the Brazos River was occupied only by Asa Mitchell's house and salt works. The locations of these structures are unknown, but descriptions indicate that they were near the river and the shoreline. On this figure they are placed in arbitrary positions for the purposes of illustration.

In 1831, a customs house, a guard barracks, a commander's quarters, and a pilot's house were added to the complex. Again, no precise locations are known for any of these structures. The pilot's house is described as being on the point of land between the river and the sea, and narratives of the Battle of Velasco indicate that the customs house was on the river bank, probably immediately between the later position of the fort and the river. The other structures have been arbitrarily placed.

In 1832, Fort Velasco was constructed. Its location can be reasonably deduced from the later position of Monument Square in the town of Velasco, which apparently was placed to contain the ruins of the fort (oral tradition).

Figure 5; Velasco and Quintana in 1852: By 1833, the Fort of Velasco was in disrepair and a town had begun to grow on the point of land north of the river. Several structures built at this time lasted through the life (United States Coastal Survey 1858) of the town. The Archer House Hotel was one of these, under construction in 1833 and, still standing in the late 1850s. The town was officially platted in late 1836 or early 1837 (Rowley 1837), but was already virtually full grown by that date.

The town peaked in vigor in about 1838, and began a slow decline as coastal trade began to reroute through the developing ports of Galveston Bay. By 1852, land transfer activity had become rare.

Quintana had begun as a group of warehouses belonging to Mckinney and Wi1liams after 1833, and by 1835 had grown to a complex of warehouses, boatslips, and residences. Most of these still stood in 1852, but as in velasco, the vigor of the town was in decline.

Figure 6; Velasco and Quintana, 1890: By 1890, at least four major storms had affected the buildings of Velasco and Quintana, and few survived. The map (Goode 1890) from which this figure is derived gives 


\section{TABLE 1. STRUCTURAL HISTORY OF VELASCO: AN OUTLINE}

ca. 1824 Asa Mitchell builds his home, which probably included an inn and general store.

ca. 1826 Mitchell established salt works in the area.

1831 Brazos Hotel established "at the house of Mr. Asa Mitchel1." A1so standing at this time were a pilot's house, a barracks for a garrison of Mexican soldiers, the Mexican commanders quarters and offices, and possibly a separate building serving as the customs house.

1832 Apri] 19 -- Ugartechea begins construction of Fort Velasco near the customs house.

April 28 - Cannon mounted on fort.

May 15 - Fort almost complete.

June 23 - - A11 but two buildings outside the fort are burned at the beginning of the Battle of Fort Velasco. One of the two unburned structures was the customs house; the other was an office.

1833 Fort is abandoned, town of a number of shacks and one two-story structure under construction. This was probably the beginning of the Archer House Hotel. Possibility that town had been planned by this date.

1836 Earliest recorded sales of town lots in Velasco.

1837 Date from which town plans survive. Asa Mitchell sells most of his interest in the town.

1838 Velasco Association, made up of those who held interests in the town, begins sale. Archer House Hotel found to be extending into plotted line of Second Street and adjustment made. Original town plat no longer available. At this time Archer House (Bryan 1965:53-54) described to be "large 2-story with gallery painted white." Mary Austin Holley describes ruins of Fort Velasco as within walking distance of Archer House.

1845 Lot sales in Velasco drop below nine lot exchanges per year. Effective end of growth of town.

1852 Town plan surveyed by United States Coastal Survey.

1853 First major hurricane hits Velasco.

ca. 1860 Confederate coastal defense plan map surveyed. Town has considerably fewer buildings than in 1852 .

1872 Effective beginning of renewed interest in Velasco property.

1883 First Goode map of Velasco and Quintana. Beginning of interest in building jetties at mouth of Brazos.

1883-1890 Goode map sequence showing towns of Velasco and Quintana. Construction of jetties begun in 1889 .

1891 Surfside Beach established by Texas Land and Immigration Company on site of old. Velasco. Surfside Hotel established.

1911 First recorded purchase of property by U.S. Government on which present Coast Guard Station stands. 


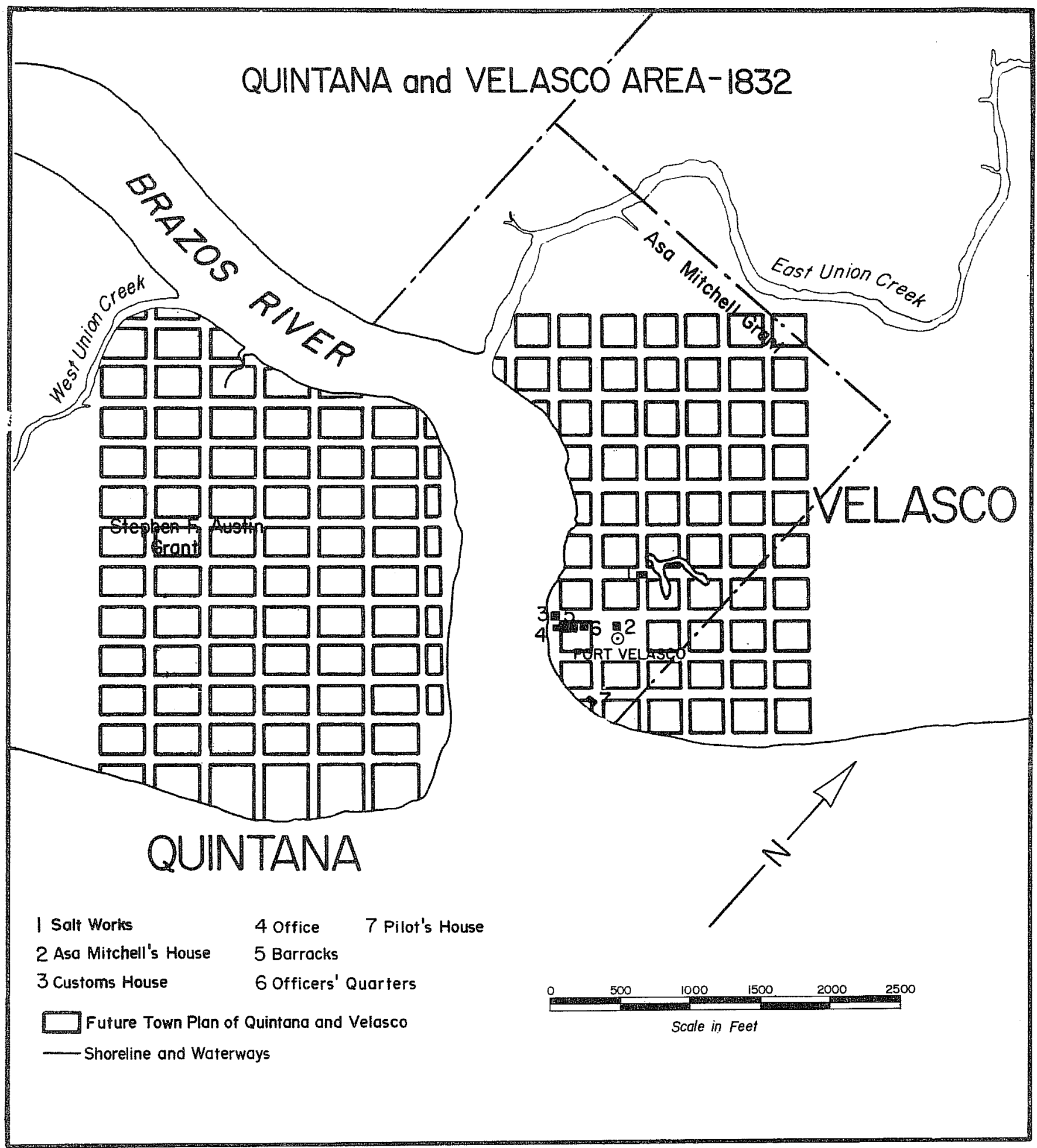

Figure 4. Quintana and Velasco Area - 1832. 


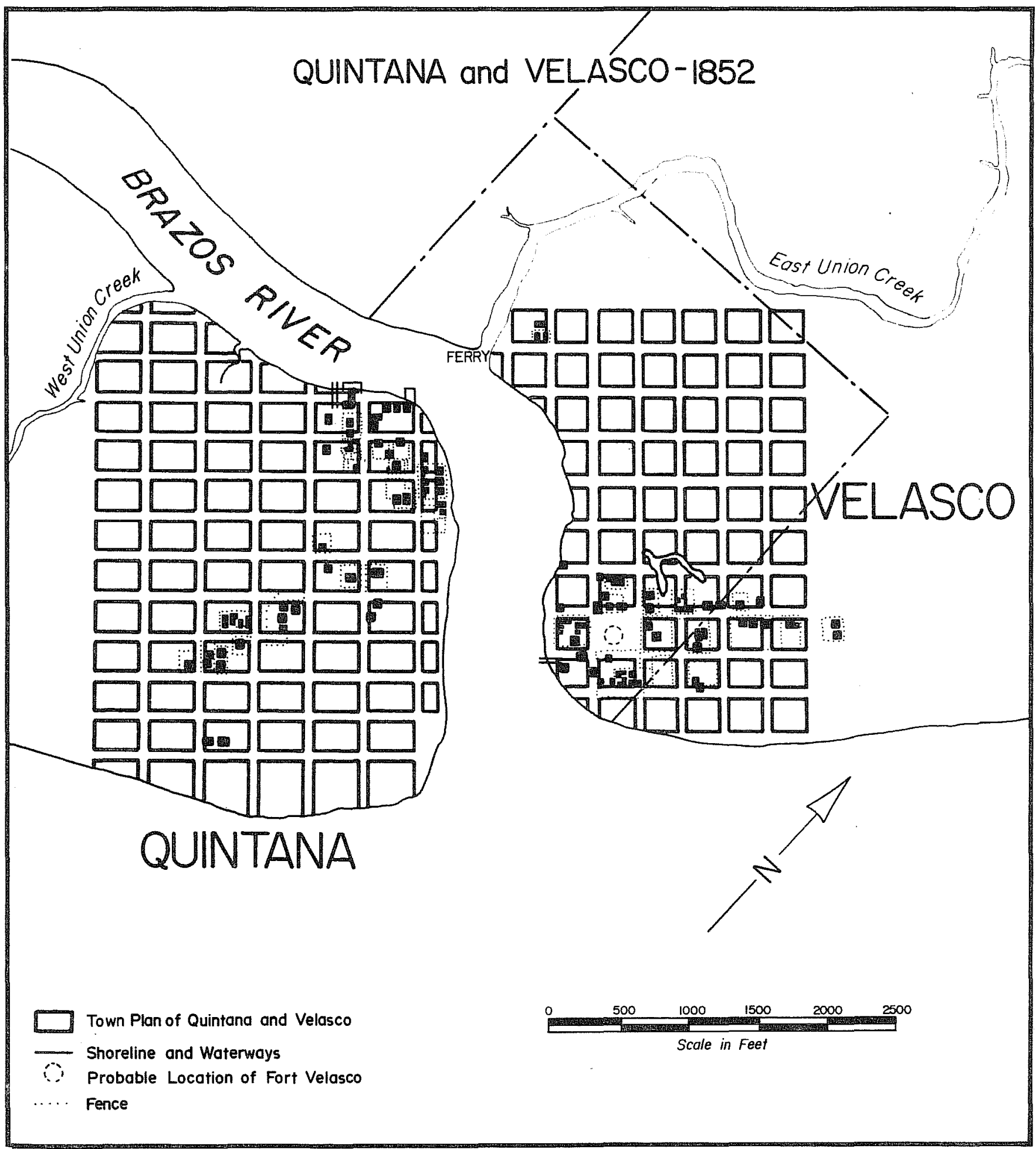

Figure 5. Quintana and Velasco Area - 1852. 


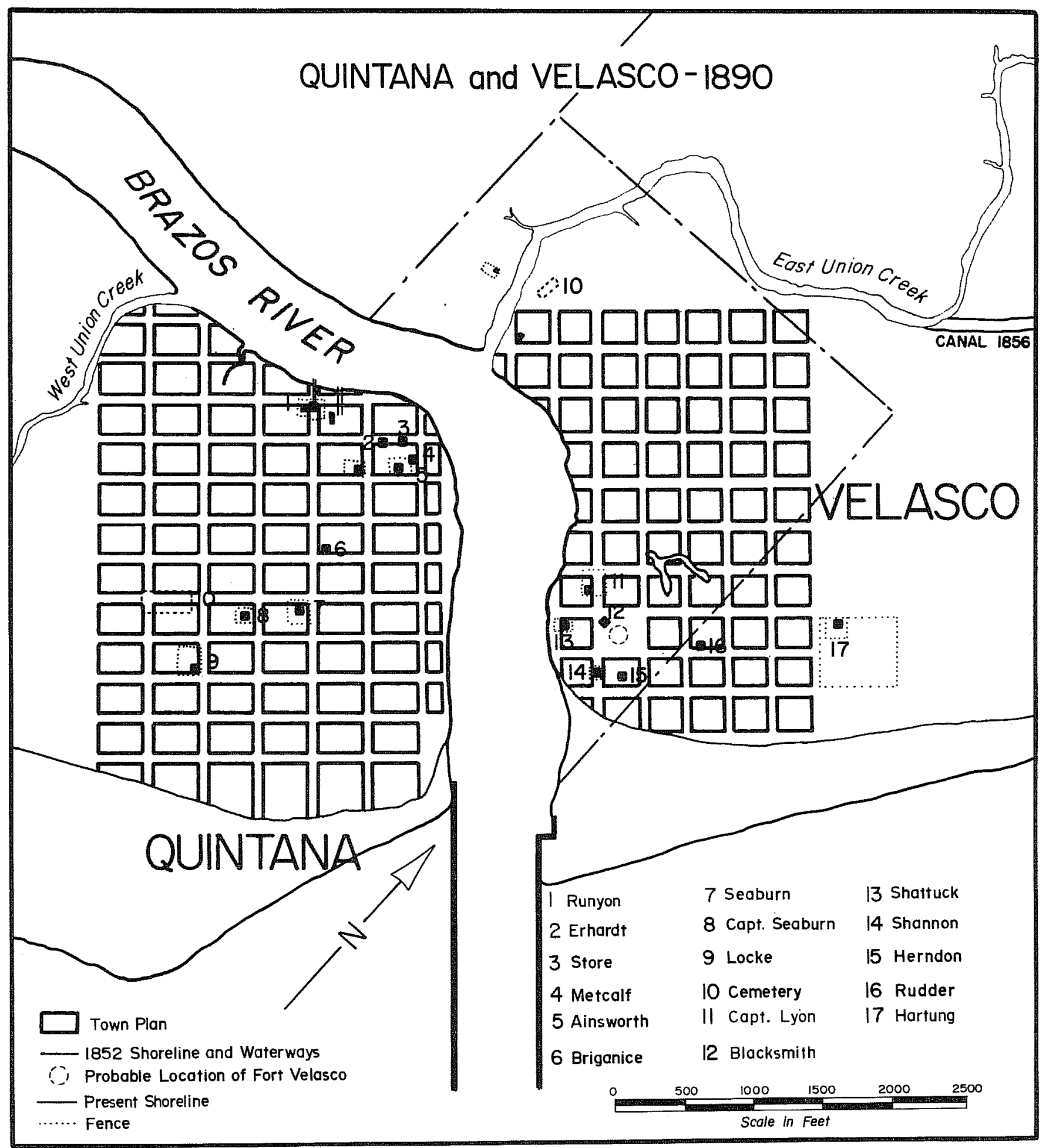

Figure 6. Quintana and Velasco Area - 1890. Blocks and streets dotted. 
us names associated with various houses. Research indicates that each name is apparently that of the occupant, not specifically the name of the owner of the property.

Figure 7; Surfside (old Velasco) and Quintana today: The shorelines, streets and blocks, and house locations of 1852 are indicated here to give an idea of the changes which have occurred in the 130 years since that plan was made. East Union Creek still survives in part, and the strange horse-shaped lagoon in Velasco still exists. One road from old Velasco apparently has continued in use throughout the life of the area. Today it is called Coast Guard Road or Avenue C. In 1837, it was called Fort Street and ran along the southeastern side of Monument Square. 


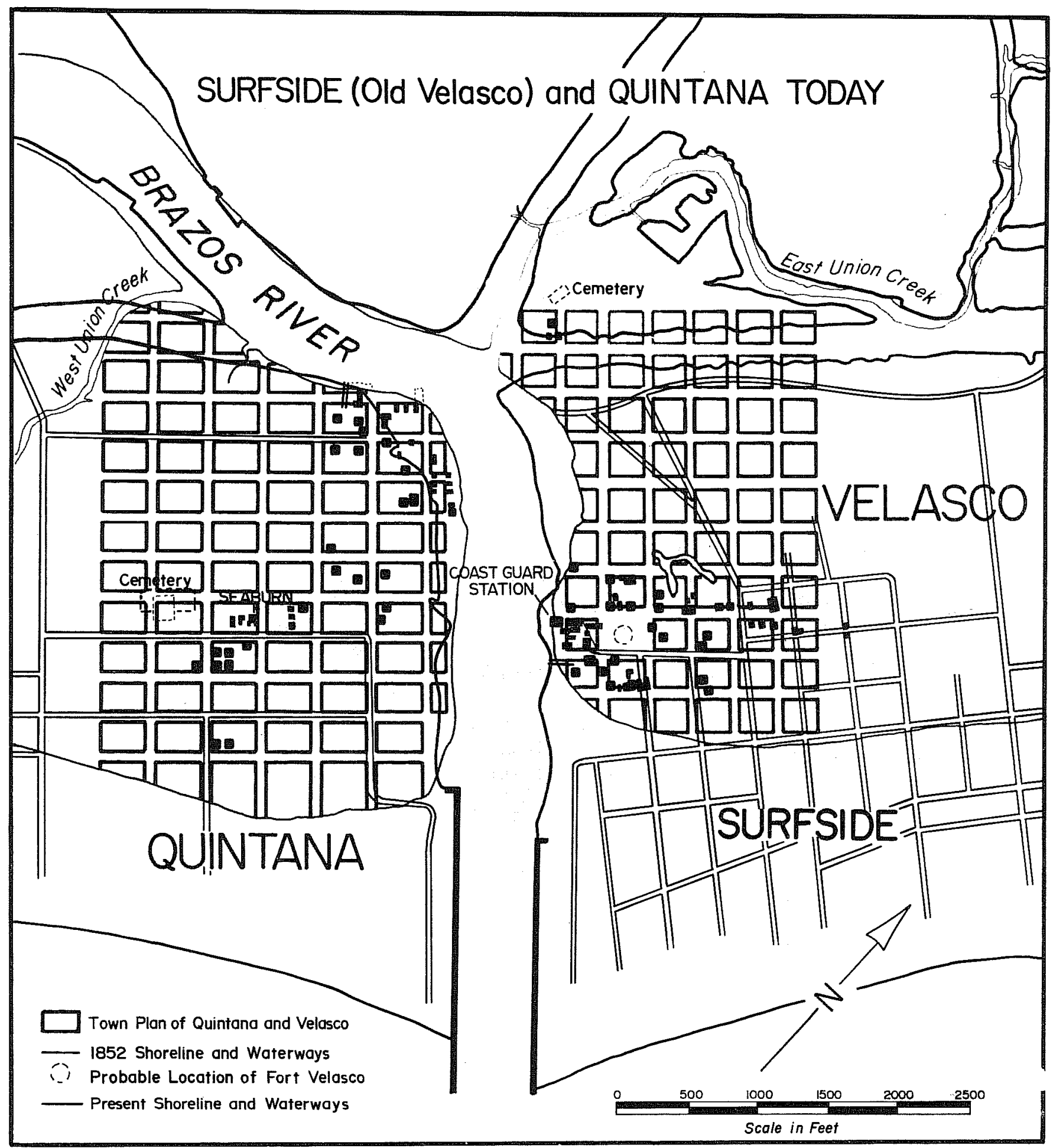

Figure 7. Surfside (oed Velasco) and Quintana Today. 


\section{INTENSIVE SURVEY AND ASSESSMENT}

Several preliminary visits to the project area by Anne A. Fox, James E. Ivey and Waynne Cox during the months previous to the survey had established contact with interested local residents and officials, and provided opportunities to become acquainted with the project site and its geological and stratigraphic makeup. These observations were to prove valuable when the time came to move the crew to Surfside and begin the second phase of the project.

\section{Methodology}

Once the roads and blocks of the original town of Velasco were tentatively located on the present ground surface, the method of investigation included an intensive survey followed by a stratigraphic test, a large number of widely separated shovel tests over the area, and a series of test excavation units to answer specific questions about the structural locations. The basic excavation unit was a 50-inch square, chosen to simplify record keeping and to open a sufficient area to allow maximum observation of both horizontal and vertical features in the soil.

A daily log of field notes was maintained. A separate record sheet was filled out for each layer within each unit. Plans and profiles were drawn and a photographic record kept of all excavations. Elevations by transit were taken of each corner of a layer as it was finished. This effort, requiring eight transit stations, assured maximum accuracy and facilitated quick comparisons of elevations between units which were often quite a distance apart (Fig. 8). The absolute height of each station was computed directly from the bench mark at the northeast corner of the Coast Guard Station, elevation 5.79 feet. A11 measurements were made in feet and tenths of feet. Grid north (aligned about 45 degrees east of true north) was established as perpendicular to the Brazos shoreline, for purposes of simplification in record keeping.

Excavation was done with trowels, except for the shovel tests, and except where noted a11 deposits were screened through 1/4-inch mesh. Units were excavated by stratigraphic layers, readily determined by changes in soil color and texture.

Artifacts were placed in bags labelled as to horizontal and vertical provenience. Each bag was assigned a lot number and returned to the Center laboratory for processing. At the laboratory the materials were checked in by lot number, washed, and catalogued, ready for analysis. A1l catalog sheets, site records and photographs have been bound into notebooks for permanent preservation.

For purposes of analysis, units were grouped according to location within the site and proximity to historic structures as understood from the research. Artifacts were tabulated by provenience and were then sorted into groups according to usage, for identification, description and comparison with those from other sites. 


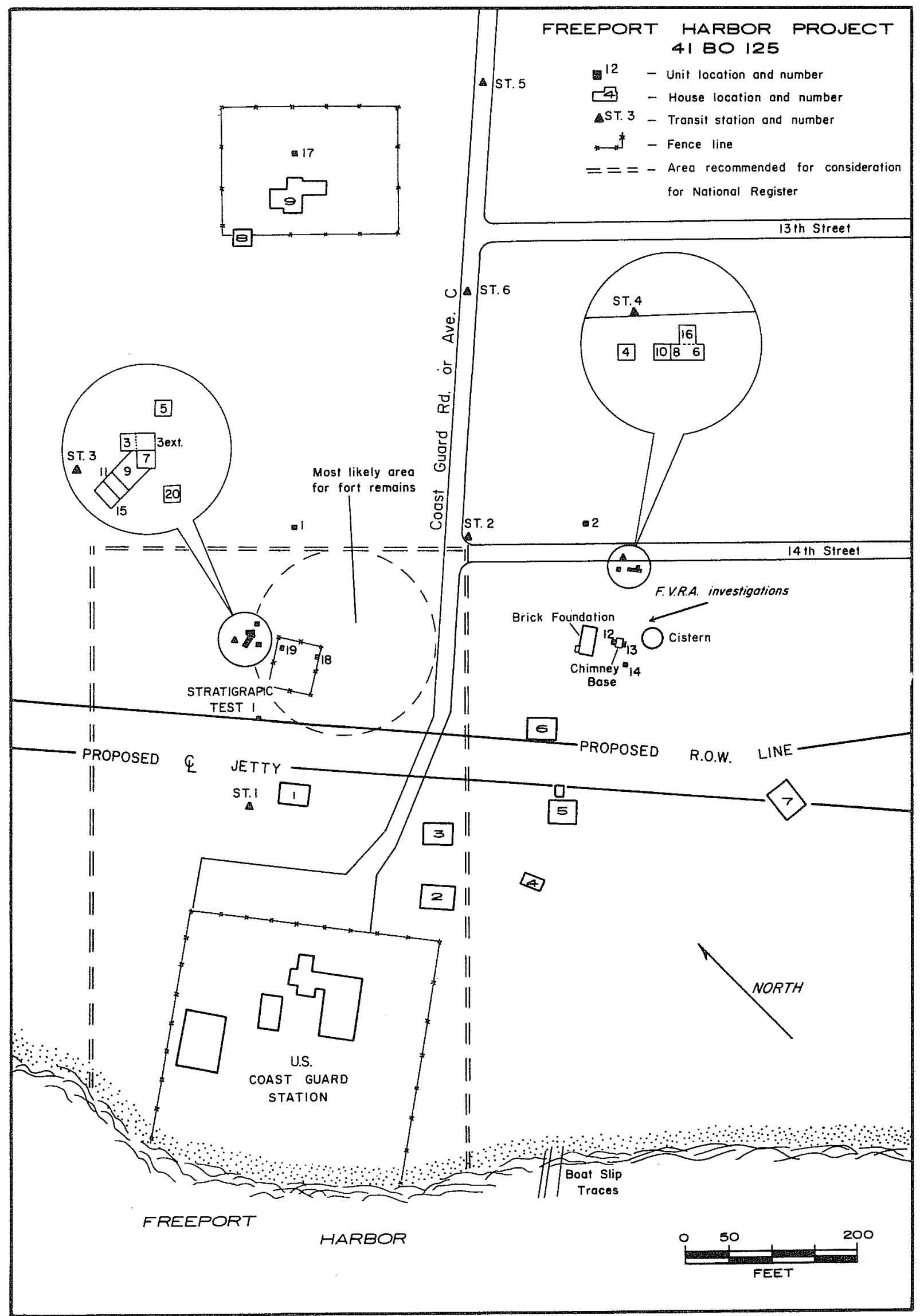

Figure 8. Freeport Harbor Project: Unit Locations. 
Animal bone recovered from the site was cleaned, tabulated, and identified by staff members. Identification was done using the faunal collection of the Center for Archaeological Research. Since the faunal recovery was neither complex nor extensive and the deposits all appeared to be disturbed, more intensive professional analysis was not done.

\section{Field Work}

The survey was begun on November 11, 1980, with a walkover of the entire project area by the archaeological crew. On the Velasco side the entire width of the project area from the canal to Surf Street was examined. The area within the project boundaries from this point to the present shoreline has been deposited and frequently reworked by the Gulf waters since 1890 (Figs. 6 and 7) and was therefore not intensively surveyed. However, most of this was surficially examined by Fox during the recording of historic buildings (see Appendix I). Several reexaminations of the Velasco side in those areas where the buildings of the town had once stood were carried out at intervals during excavation, as our understanding of the stratigraphy and its implications developed. Shovel testing in the form of holes $\mathrm{ca} .30 \mathrm{~cm}$ wide and $30 \mathrm{~cm}$ deep was carried out at the probable sites of these buildings. In each case, nothing other than a very few artifacts showing the same 1840-1970 mixture seen everywhere on the site were found.

The majority of the old town site west of Monument Square is marshland under several inches to two or more feet of water, and thinly covered with marsh grass 3-5 ft tall. Historical research indicates that no structures of note stood in these areas. A walking survey in search of surface artifact scatters was conducted over most of the areas. Those areas not examined were avoided because they looked unsafe because of water or mud depth, or because they were covered by obvious mounds of dredging backdirt.

Since the previous visits, the clearcut stratigraphy visible in the banks of the river channel had become silted over as a result of Hurricane Allan and canal dredging. The areas previously investigated by Lynn and Hole on the Quintana side were reexamined. Fortunately, on a previous visit to the site, careful examinations had been made of these sites, since these also had by this time been nearly obliterated.

It was decided to begin the field work on the northeast, or Surfside bank of the river, then to move the focus of the operation to the opposite, or Quintana shoreline.

Stratigraphic Test No. 1

This 50-inch square unit was laid out just grid north of a smal1 frame house on the edge of a clump of salt cedars, within the general area believed to be Monument Square (Fig. 9). The first layer, removed without screening, was 3.5 inches thick and contained predominantly dark sandy soil, grass, and random recent trash. The second layer contained 


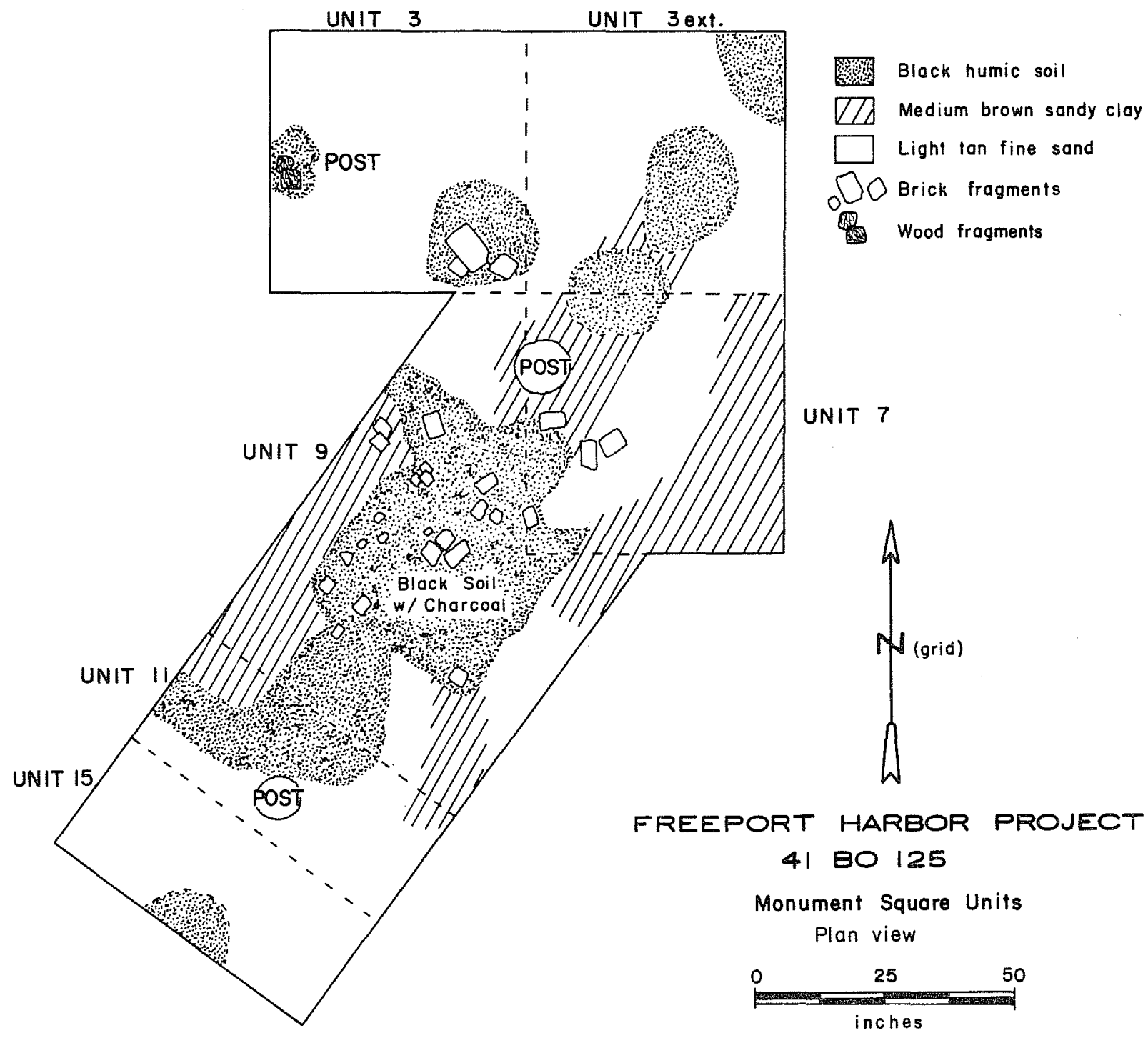

Figure 9. Monument Square Units, Plan View. 
rusted tin can fragments and nails. Fragments of red brick and contemporary ceramics and glass artifacts were also present in a lighter $\tan$, sandy clay. Within this layer, two deeper trash pits were found. Designated P. 1 and P2, they were 16 inches and 19 inches, respectively, in diameter and rather shallow. They contained dark gray sandy soil in which were packed numerous fragments of rusted tin cans and other unidentifiable objects. They also contained whole and partial bottles of clear glass, primarily with screw tops, and a few sherds of ceramics. The majority of these artifacts dated to the post-1900 period. Layer 3 in this unit consisted of sterile, light tan sand.

Apparently this area has been a trash dump since the early 19 th century. Pieces of metal and glass bottles are strewn about beneath a dense cover of vines. The only early 19th century artifacts present were a few sherds of blue hand-painted and blue transfer wares. These were mixed in with fragments of recent, clear glass screw-top jars indicating total disturbance of the deposit in this area.

\section{Unit 1}

This was a 50-inch square unit located on the north side of Monument Square (Fig. 10,a). Layer 1 was 4 inches of humic, dark brown sandy soil which overlaid a 1-inch thick deposit of asphalt or tar. Artifacts in this layer included transfer-printed English ceramics popular in the early 19th century mixed with fragments of recent glass jars and bottles, bricks and pieces of composition tile. Beneath the asphalt layer was a stratum of light gray to tan sandy soil bearing ceramics of the early to the late 19th century. Also present in this layer were fragments of glass representing dark green wine bottles, an embossed late 19th century panel bottle and brown and bright green fragments which could be from 20 th century beverage bottles. Fragments of transfer ware from this layer bear designs identical to those from layer 1 above the asphalt. Layer 3 was sterile, light tan sand which continued to 20 inches. At this point the water table was reached and excavation ceased.

While this test unit indicates that considerable disturbance has taken place in the area, there is not as much post-1900 material here as at Stratifigraphic Test No. 1. Evidently the asphalt deposit does not separate strata of differing time periods.

At this point a series of shovel tests was excavated to the north and west of Unit 1 within a radius of 250 feet. This testing was prompted by 1ocal informants' statements that the Fort Velasco Restoration Association excavations had found that the artifact bearing surface extended no more than 30 inches below the surface in block 568 . Since the surface of block 568 is approximately one foot higher than that at Unit 1, it appeared that the artifact bearing layer would be thinner, going in this direction. Testing showed that the artifact bearing layer becomes progressively thinner as one moves toward grid north. Subsequent tests indicated that the asphalt zone becomes thicker toward the southwest, becoming a pavementlike mass 50 feet southwest of Unit 1 . 


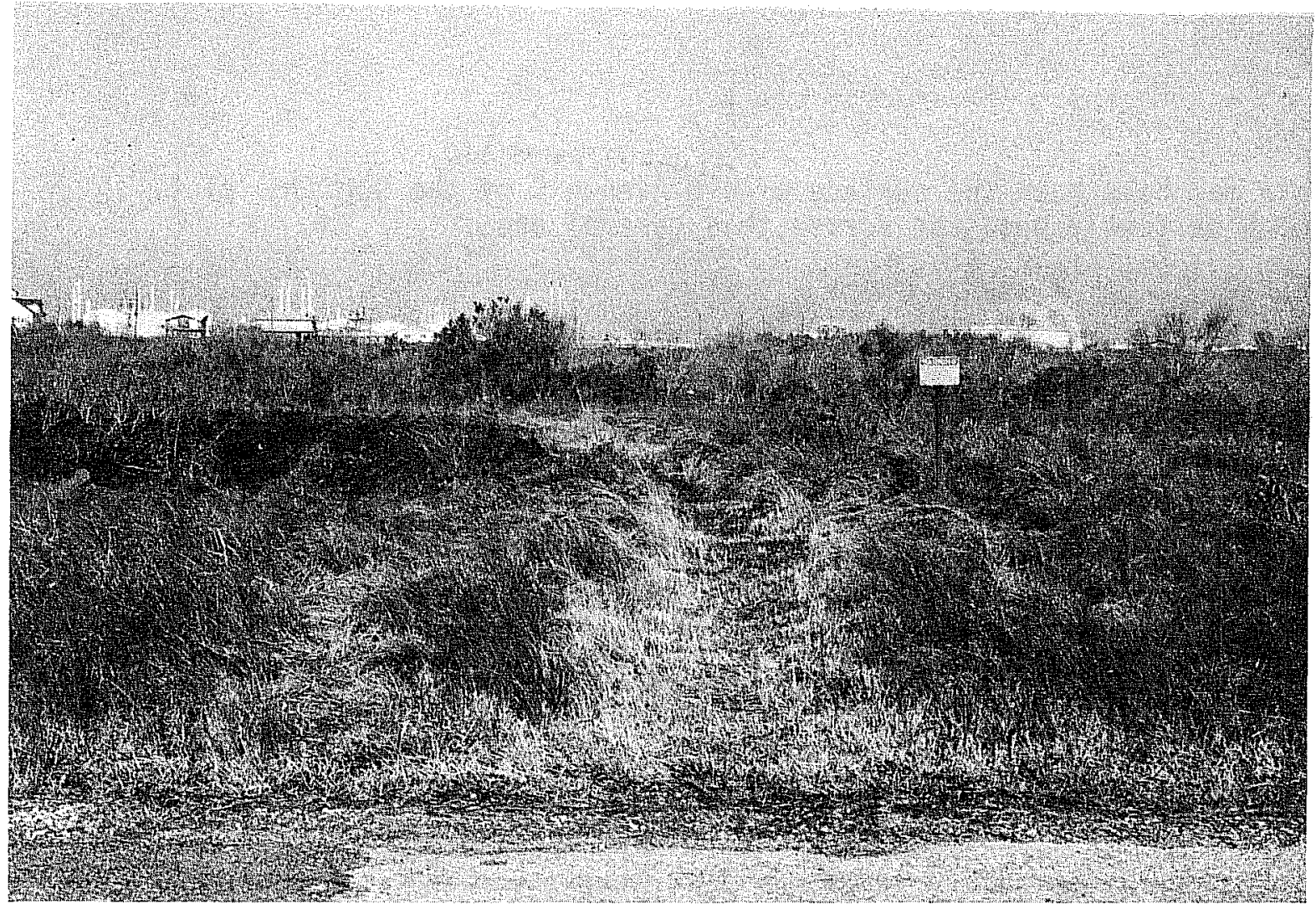

a

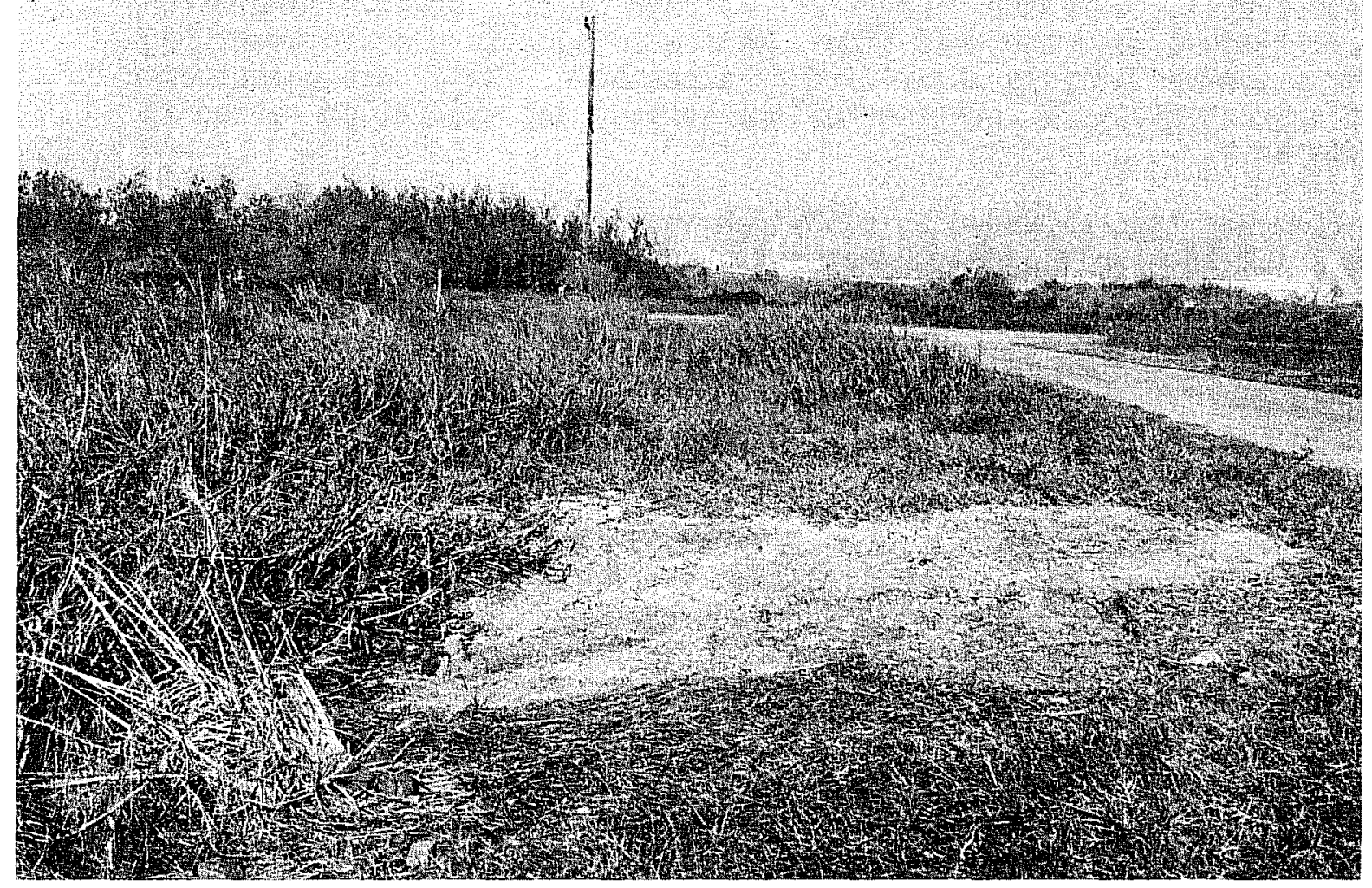

b

Figure 10. Monument Square Excavations, Photographs. a, north side of Monument Square, general area of Unit 1, looking west; b, Archer House Hotel area looking northwest. 
This may have been the surface of old Avenue $C$ of the Surfside plat, which evidently once ran across this general area.

\section{Unit 2}

This unit was a 50-inch square excavation, laid out on the north edge of present 14th Street within the general vicinity of the site of the Archer House Hotel (Fig. 10,b). It was found to be over a modern gas pipeline and was abandoned.

\section{Units $3,5,7,9,11$, and 15}

The above mentioned shovel tests had indicated a concentration of brick fragments and other artifacts at 6 inches below the surface in an area about 100-150 feet southwest of Unit 1. Unit 3, a 50-inch square unit, was Taid out in this area (Fig. 11,a). Layer 1, actually the equivalent of layers 1 and 2 in the previous units, consisted of 3-4 inches of dark gray to black sandy loam which became more densely black toward the southeast corner. In this corner was found a shallow, pitlike depression which contained a number of brick fragments. Other similar fragments were scattered about the area. No other artifacts were present at this location. However, elsewhere in this layer were found fragments of brick, shell, glass, a badly rusted nail and one sherd of an English blue transfer ware cup. Layer 2 consisted of tan, sterile sand with a dark feature near the west side. This was found to contain wood fragments and tentatively identified as a posthole. Water was encountered at approximately 24 inches below the surface and excavation ceased in this unit.

Unit 3 was then expanded by a 50-inch square unit to the east to form a $50 \times 100$-inch unit. Brick fragments and another sherd of the transfer ware cup were recovered from layer 1. The bottom of this layer was found to be very uneven with dips in the center and the northeast corner. Subsequent clearing of the surface of layer 2 revealed three features. These consisted of brown to black sandy humus in round-tooval shapes. These had brick fragments associated with them. Investigation of these features was stopped when the water level was reached.

Subsequent Units $7,9,11$, and 15 were laid out in this vicinity in order to explore the possibility that these features were an alignment of postholes (see Fig. 11,b). In each of these units, the first layer consisted of a dark humus containing brick fragments, which graded into a light tan sand. Scattered concentrations of brick and charcoal were found in close conjunction with a line of postholes and surviving post fragments. These suggested that this was the badly disturbed remains of a 19 th century house foundation and a brick chimney base. The fact that relatively few artifacts were present tends to confirm the impression that this was an area beneath a structure which may have burned. The shape and design of the transfer ware cup of which a totaled 19 sherds were found in this group of units, plus the presence of a number of 


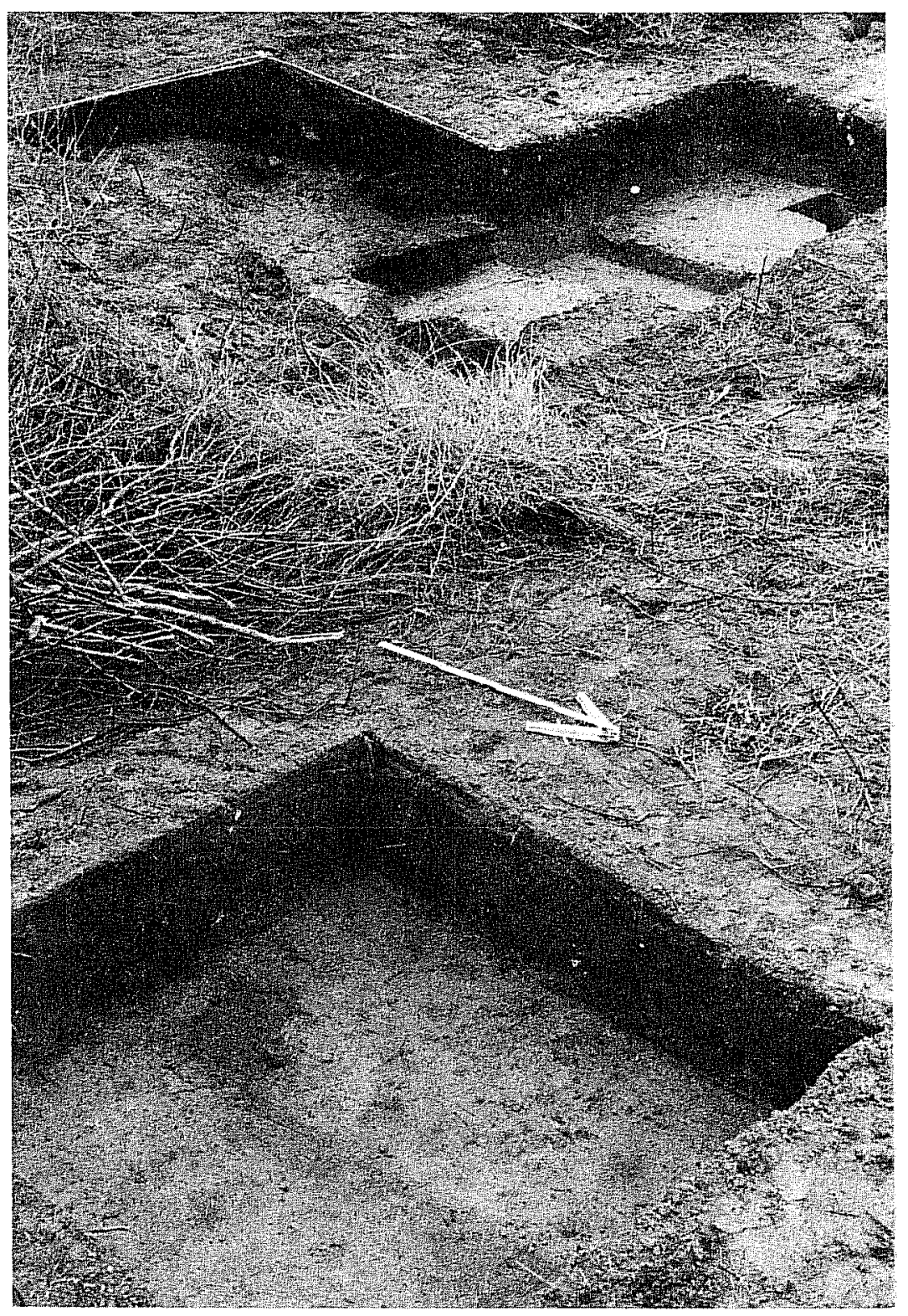

a

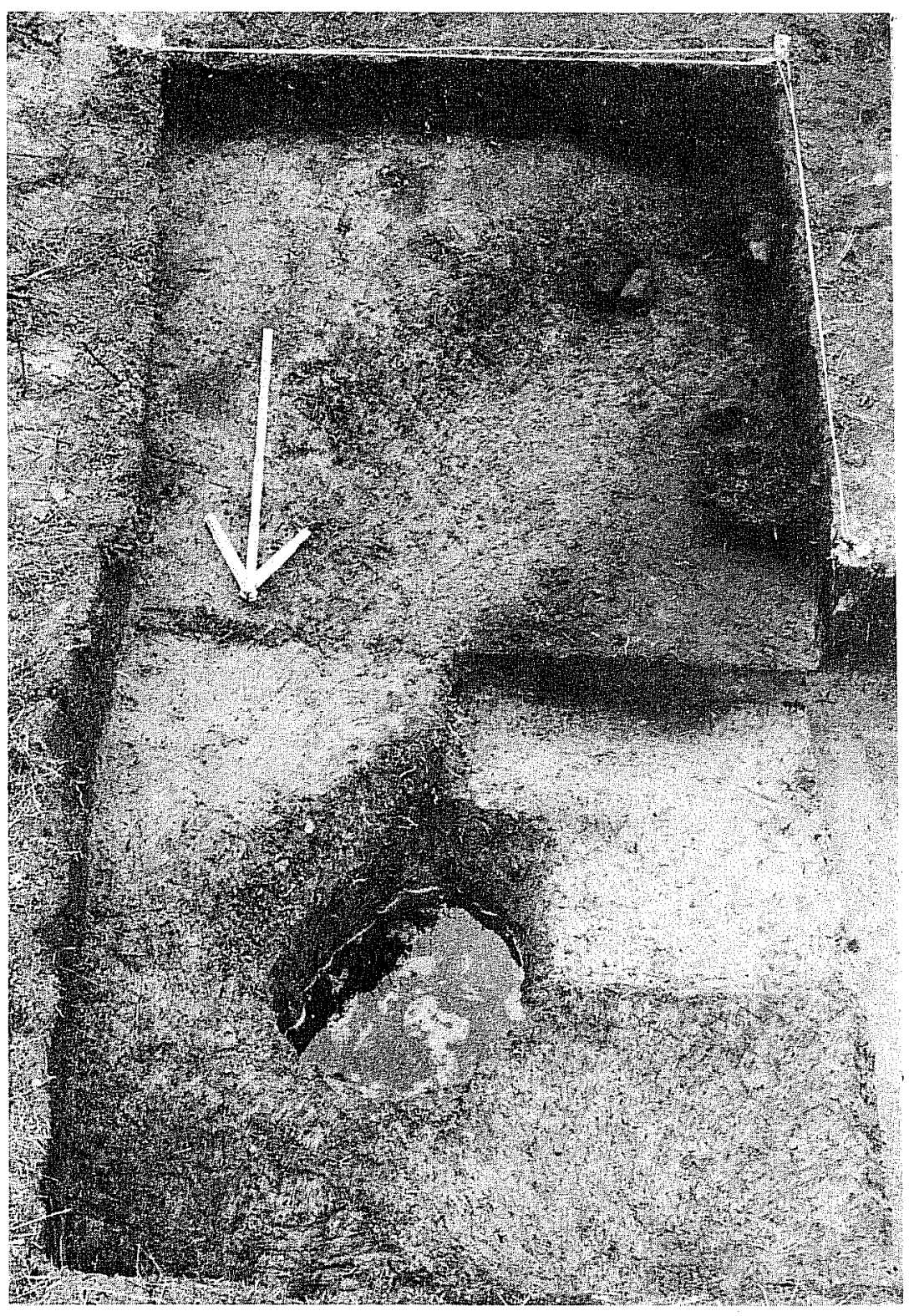

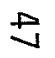

Figure 11. Excavation Areas, General Views. a, Units 3, 5, and 7, looking southwest; b, closer view from north showing post in place and water level. 
sherds of other English ceramics, would appear to date the use of the structure to the first half of the 19th century. The fact that a thimble was found there and the delicacy of the cup in question suggests the presence of a household rather than a military establishment such as Fort Velasco.

Units 18,19 , and 20

These were 50 -inch square units laid out across what was recently a fenced area near the center of Monument Square (Fig. 9). They proved to be almost completely sterile, yielding only a few contemporary nails and glass fragments and no indications of structural remains.

Units $4,6,8,10$, and 16

These were excavated on the south edge of 14th Street (Fig. 8) where the Fort Velasco Restoration Association (FVRA) reported finding a remnant of a brick wall (Howard Fearn, personal communication). Since it seemed likely that the foundations found farther to the south in this lot were a part of the Herndon House (Fig. 6) this might possibly be a portion of the Archer House Hotel.

Unit 4 was a 50-inch square unit, laid out centering on the area indicated as containing the wa11. A gray-brown to brown soil containing a high percentage of sand and broken shell yielded occasional sherds of early 19th century ceramics, rusted nails, glass, and brick. No semblance of a wall was found. Sterile tan sand was encountered ca. 1 foot below the surface. Moving slightly grid east, Units 6, 8, 10, and 16 were excavated. A confusion of lenses of various colors and textures of sandy soil was encountered (Fig. 12). While bricks were present, they did not form any sort of structure but rather appeared to be groupings of rubble. Round disturbances were identified as planting holes for shrubs. There were also animal burrows present. One quadrant of Unit 16 was excavated through the sterile white sand to the water table at a depth of 31 inches.

Artifacts recovered in these excavations represented the entire time period from the early 19th century to the present. The glass included early olive and "black glass" wine bottles as well as clear-colored contemporary screw-top jars and brown glass beer bottles. Ceramics ran the gamut from early 19th century English wares to late 19th century ironstone. Fragments of tin cans and heavy rusted scrap metal were also found. Building materials present were window glass, nails, composition tile, and cement mortar. These artifacts were thoroughly mixed within the deposits. In several cases, contemporary clear glass container fragments were found near the bottom of units in direct association with early 19th century ceramics.

Although it seems most likely that the Archer House was located in this general vicinity, it became apparent that no trace of its structure 


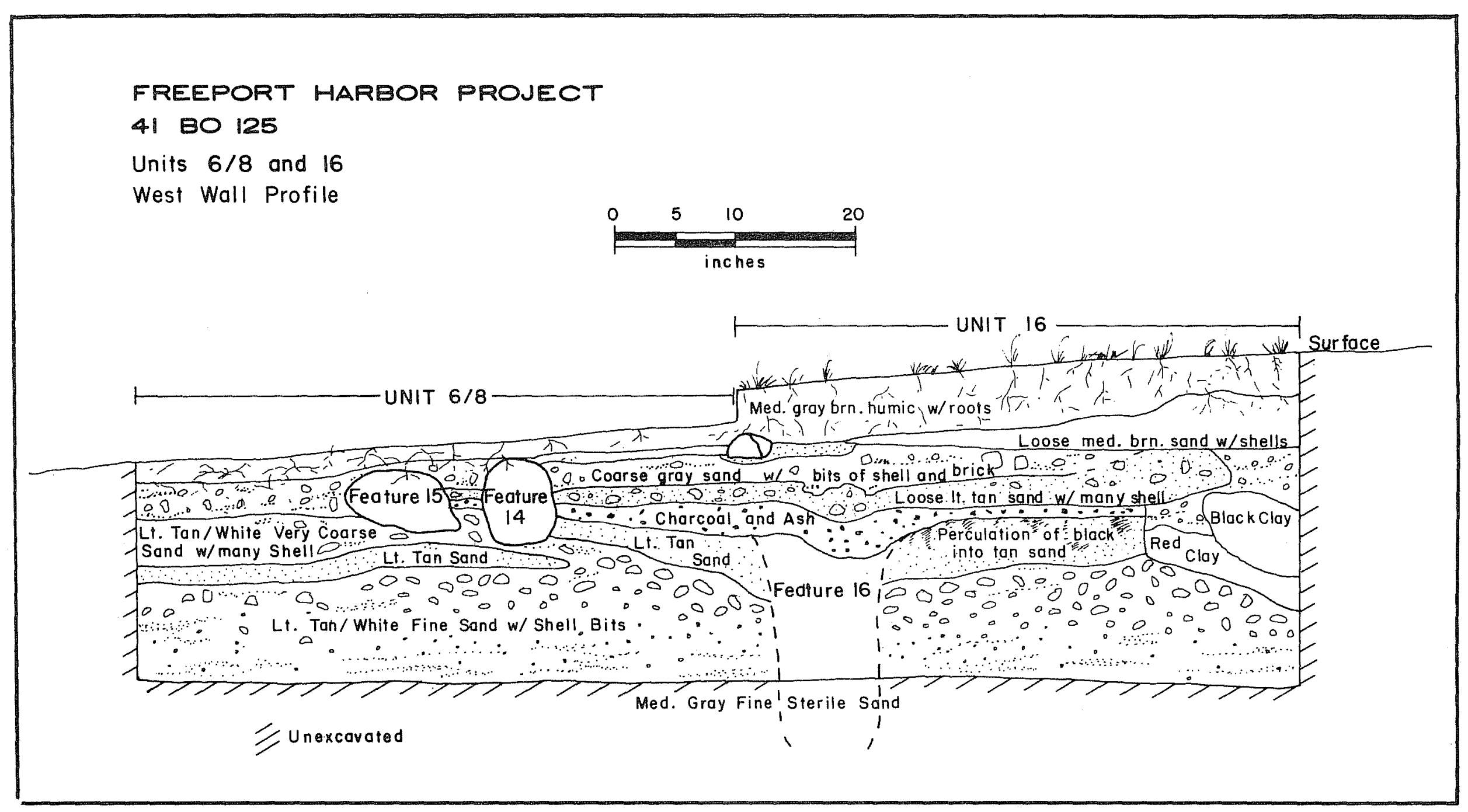

Figure 12. Units $6 / 8$ and 16 . West Wa 11 Profile. 
remains in place on this side of the road, and that the cultural deposits have been completely disturbed. This has probably been the result of numerous storms, flooding, and road construction.

Units 12,13 , and 14

According to local informants, the Fort Velasco Restoration Association (FVRA) located and exposed, in addition to the brick wa 71 mentioned above, a brick house foundation, an isolated brick fireplace base, and a brick cistern (Fig. 8). Although it was apparent that the area had undergone considerable disturbance during these activities, it was decided to test within the area for structural clues which might help to locate the Herndon House. It was also hoped that if a remnant of undisturbed ground could be found, there might be some of the original stratigraphy preserved.

Units 12 and 13, each $50 \times 100$ inches were laid out east and west of the isolated chimney base, in an attempt to find structural remains in association with the chimney. Before stratified excavations began, the areas were cleared of mounds of what appeared to be backdirt from the FVRA excavations (indicated in Table 2 as $12 \mathrm{CU}$ and $13 \mathrm{CU}$ ). Artifacts were recovered as noticed during this operation, but the material was not screened. It soon became apparent that the deposits in both units still consisted primarily of disturbed artifactual materials, in a loose, gray-brown sandy soil. A number of darker brown disturbances were encountered in Unit 12 which may have been postholes but there was too much disturbance in the unit to be certain. White, sterile sand was found at the base of the brick foundation at approximately 7.46 inches below the ground surface in the immediate area.

Unit 14 was then opened to the southeast of Unit 13, in an area which appeared to be undisturbed. After 3-4 inches of fairly sterile soil had been removed, a layer of dark gray-brown sandy soil was found to contain the same assortment of artifacts as found in a11 layers of Units 12 and 13. No structural features were found in this unit.

The artifact yield was extremely high in comparison with other areas of the townsite and the assortment included quite a range of dates, from late prehistoric Indian, represented by one sherd of aboriginal pottery, to post-1900 ceramics and contemporary beer and Clorox bottles. However, here as in the units to the north the deposits were thoroughly mixed and confused. Apparently the inhabitants of the squatters' shack, removed by the FVRA when they started clearing the lot, dumped their trash on top of the already confused mid-19th century deposits from the Herndon House. Then later excavations and earthmoving, in connection with the FVRA excavations, thoroughly mixed the accumulation. Heavy 20 th century concrete objects of unknown origin have also at sometime been piled on one side of this lot, by the FVRA to use in future reconstruction of Fort Velasco (George Kramig, personal communication). 
Unit 17

In an attempt to tie the 1858 map to an actual structure in the ground, an excavation unit was laid out just north of an abandoned farmhouse in Surfside lot 559 identified as the Schuster House. According to local informants, an old house originally stood on this approximate location. This would have been the structure identified on early maps as the "Rudder" house (Fig. 6), which was acquired by George Schuster in the 1880s. His grandson, now approximately 72 , was born in that house and relates that it burned in the 1920s. The present house is supposed to have been built soon after the first one burned. A member of the Schuster family married the commander of the Coast Guard Station in the 1920s, and a small house north of the station was built for them (see Appendix I).

Unit 17, a 50-inch square unit, was placed where the Rudder House should have been located, according to the early maps. The first layer consisted of ca. 14 inches of dark brown sandy loam which contained late 19 th and early 20th century artifacts and local brick fragments. At this point a 1 to 1-1/2 inch thick layer of asphalt was found, similar to that in Unit 1. Beneath the asphalt the dark brown, sandy soil contained ironstone, early 19th century transfer and banded slip decorated earthenware and porcelain sherds, numerous brick fragments, pieces of window glass and nails. A sherd with a Rockingham glaze from this layer cross-mended with one from the first layer. Porcelain doll parts were also present above and below the asphalt.

Two postholes were discovered in this layer, dug through it into sterile, tan sand. Numerous badly rusted nails lay on the surface of the sand. The postholes contained fragments of 8-inch diameter posts. Since the posts were on 7 y 25 inches apart, center to center, it does not appear that they were part of a house foundation. However, the amount of building debris in the layers below the asphalt strongly suggests that a structure was once in the immediate vicinity, and the artifacts point to an early 19th century date of occupation.

\section{Quintana}

The documentary research indicated that only a comparatively smal1 portion of the remains of historic Quintana might be included within the survey area. A careful surface examination of the survey area on the south side of the river as far east as the 1890 shoreline was done by the crew. No surface indications were found of further structural remains. Early 19th century artifacts were found washing up on the shoreline toward the western end of the survey area, probably from house sites now beneath the water where the shoreline has receded since that time (Fig. 5).

Two man-made earthen mounds which support World War II gun emplacements are located in the area of post-1890 de1taic accretion on the Quintana side of the channel. These were recorded and described in some detail 
by Ippolito and Baxter (1976:21) and given the site designation 41 B0 116 . After careful examination of the site and of the geology and history of the area, it is the considered opinion of the authors that the Civil War gun emplacements were located approximately .2 miles to the northwest of this point. It is possible that the cut stone used in construction of the World War II gun emplacements was salvaged from the Confederate site, but the formation of this area has been too recent for it to contain Civil War fortifications. 


\section{ARTIFACT DESCRIPTIONS}

For purposes of description and analysis, the artifacts recovered have been organized into categories according to probable use (Table 2). Since such a large proportion of the artifacts was recovered from totally disturbed deposits, and there has been so much local dumping in the area, descriptions wil1 be limited to general categories, with special attention given to individual objects which may have relevance to the 19th century occupation of Velasco as a whole. All artifacts illustrated are full size unless otherwise indicated.

Kitchen/Dining Activities

Included in this group are all objects which would ordinarily pertain to the preparation, serving and consumption of meals.

Ceramics: (Figs. 13, 14; Total 1092 sherds)

The artifact collection includes a complete range of ceramics from a few prehistoric sherds to contemporary chinawares and Coast Guard-issued ironstone plates and cups. For purposes of analysis, these have been divided into groups which tend to reflect both the method of manufacture and their comparative period of poputarity.

Unglazed ware: Sandy paste aboriginal sherds with very fine shell or bone tempering. One sherd was found on the Velasco side. No other prehistoric artifacts were in the area. Three similar sherds were found on the Quintana shoreline, probably some of the last remnants of a site now inundated. According to Lynn (1979:24) a prehistoric shell midden was once located in this general area.

Lead-glazed wares: Sandy paste vessels with a lead glaze, made in Mexico. Two sherds from Velasco have a red body and mahogany-colored glaze and resemble sherds from early 19th century deposits in the San Antonio area. Two thick sandy paste sherds from Quintana with the remains of a lead glaze are from contemporary Mexican-made flower pots.

Decorated whitewares: White paste earthenwares decorated in a variety of ways were imported from England in great quantities during the first half of the 19th century. Representatives of this type of ware were found in every excavation unit on Velasco, as well as on the shoreline at Quintana. Since these wares have been described in detail in numerous archaeological publications (see Nöel Hume 1969:128-133; Davis and Corbin 1967:15-27), we will refer to them by their commonly used names and not describe each variety. Edged, or shell-edged wares included molded but unpainted varieties, and biue, green, and yellow-painted varieties. Several hand-painted designs were represented (Fig. 13,a), decorated in shades of rose, green, blue, yellow, often with black accents and rim bands. Most of the varieties were identical to sherds found on early 19th century sites throughout Texas. Two rose and green 
Figure 13. various Ceramics and Glass Containers.

a. Blue, orange, and yellow hand-painted cup, early 19th century (6/8$\left.4^{*}\right)$

b. Blue and yellow hand-painted plate, late 19th century shape, but early design (12 CU**)

c. Victorian majolica, early 20th century (12 CU)

d. Rose, green, and black design, late 19th century shape (13-2)

e. Rose and green design, early 20th century shape (12 CU)

f. Rose, green, and black with yellow background, cup and saucer (12-3, $6 / 8 \mathrm{CU})$

g. Mocha design in black and shades of brown $(6 / 8 \mathrm{CU})$

h. Banded slipware pitcher in blue, tan, and brown (14-3)

i. Overglaze blue bird decoration on sugar bowl 1id, early 20th century (ST 1-2)

j. Overglaze decal design in lavender and peach on porcelain saucer, post-1900 (12 CU)

k. Clear glass bottle made by Owens-I17inois Glass Company, 1929-1954 (Toulouse 1971:403) (12 CU)

1. Pale green panel bottle, lettered " . . DY/ . . RK," probably ca. 1880 (Kendrick 1967:22) (1-2)

m. Two aqua medicine bottles, pontils, lettered "... ER's." Similar in size and appearance to Essence of Peppermint bottles ca. 1800 to 1850 (Hanson 1981: 10-11) (14-2)

n. Irridescent, pale green medicine bottle, no lettering, probably ca. 1860 (Kendrick 1967:20) (14-2)

*Numbers in parentheses refer to unit and level within the unit where artifact was found.

**Clean up (CU) indicates artifacts found during clean up of units after tropical storm of November 14-15, 1981 


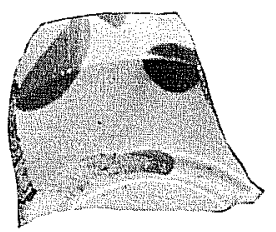

a

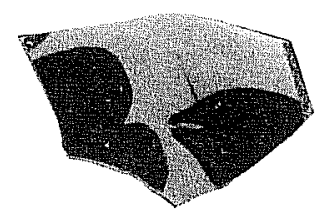

e

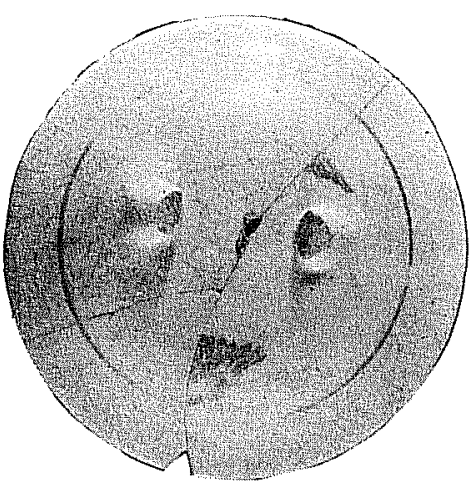

i

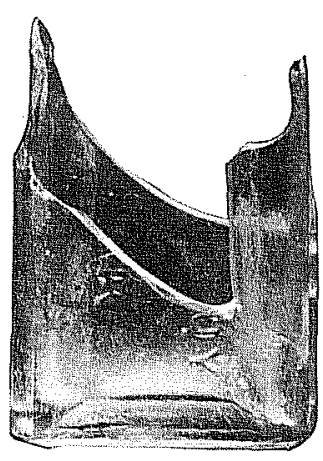

I

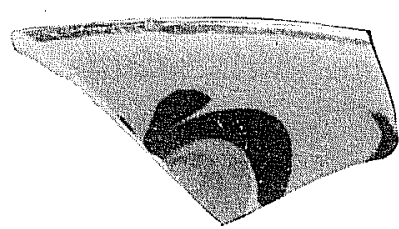

b

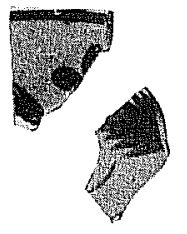

$f$
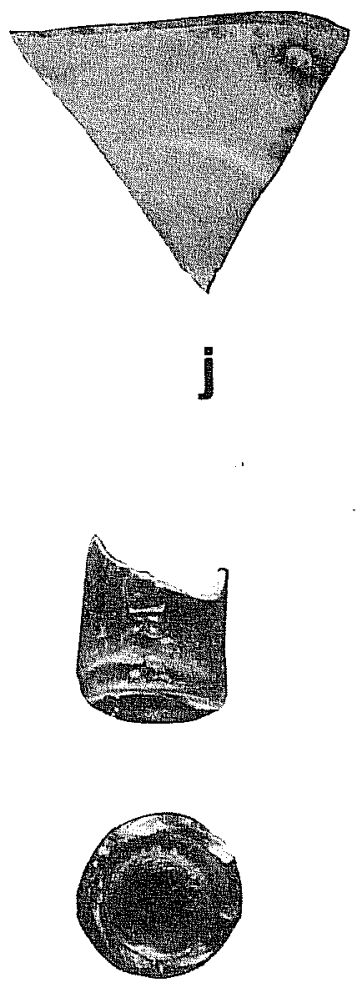

m

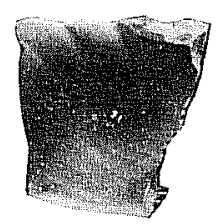

c

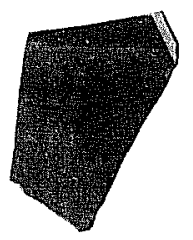

g

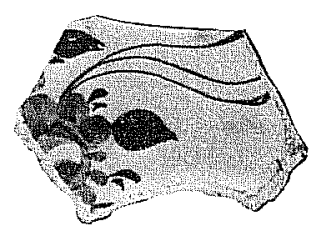

d
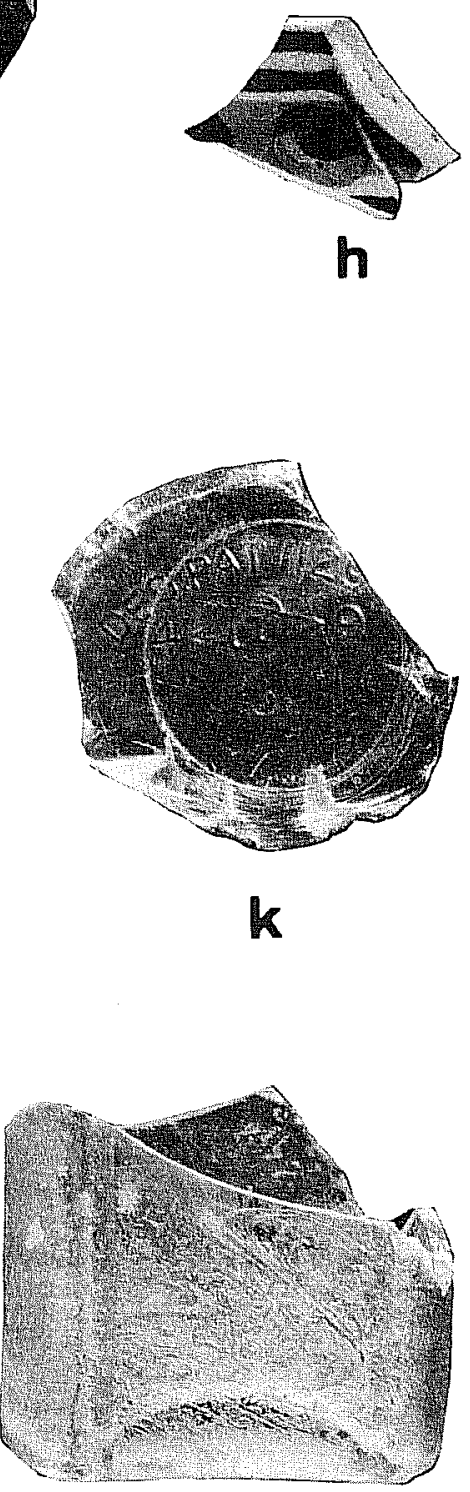

11

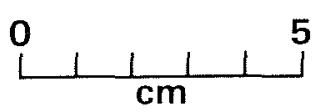

Figure 13. Various Ceramics and Glass Containers. 
Figure 14. Transferwares and whitewares.

a. Blue floral transfer plate $(13-1 *)$

b. Purple floral transfer saucer (12-1)

c. Blue floral transfer plate (13-1)

d. Dark blue transfer cup, early 19th century (9-1)

e. Mutberry historic scene bowt (12 CU**)

f. Red floral transfer plate (16-2)

g. Blue willow pattern plate (12 CU)

h. Maker's mark, "DAVENPORT." Longport, Staffordshire, 1793-1887 (Godden 1964:189) (Pollan collection)

i. Maker's mark, "Chinese Pastime/Davenport." Longport, 1820-1860 (ibid.:358) (Surface near Unit 13)

j. Maker's mark, "E.J." possibly Elijah Jones, Cobridge, 1831-1839 (ibid.:358) (13-1, 13 CU)

k. Importer's mark, "Henderson and Walton/Importers/New Orleans." Henderson, Walton and Co. Operating in 1835-1836 (Freeman 1980:30) (Pollan collection)

1. Importer's mark, "Henderson, Walton and Co." (ibid.) (13 CU)

m. Ironstone tureen, mid-19th century (14-2)

n. Ironstone cup, mid-to-late 19th century (14-2)

0. Ironstone plate, mid-19th century (14-2)

p. Stoneware plate with U.S. Coast Guard emblem, 20th century (12 CU)

q. Common whiteware plate, 20th century (13-2)

r. Stoneware cup, 20th century (12-1)

*Numbers in parentheses refer to unit and level within the unit where artifact was found.

**Clean up (CU) indicates artifacts found during clean up of units after tropical storm of November 14-15, 1981. 

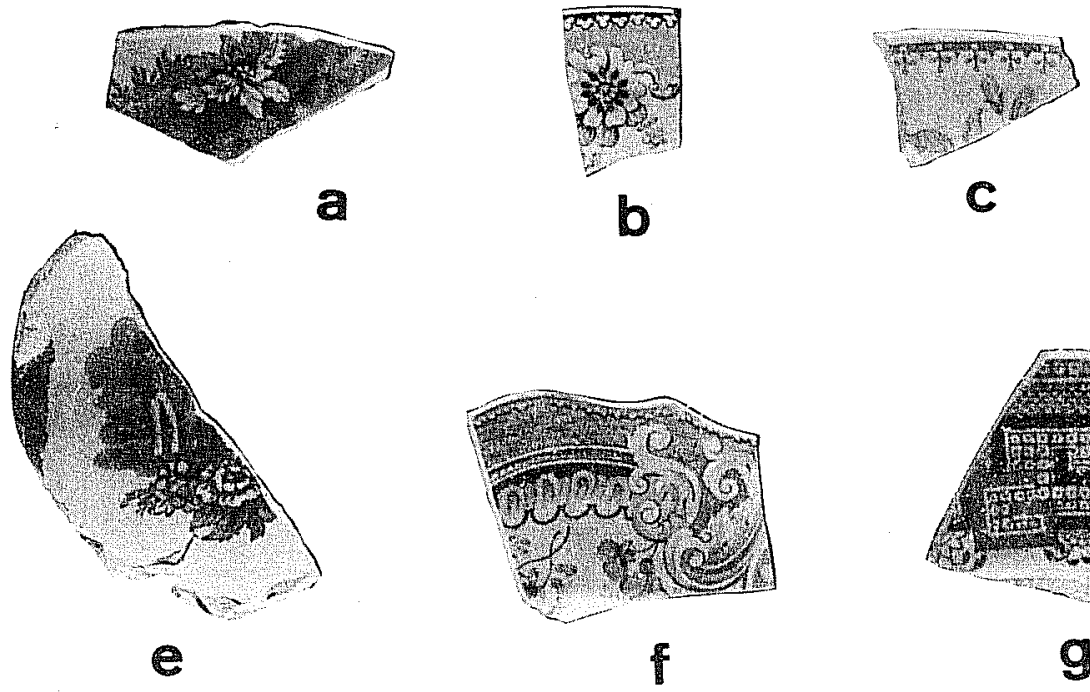

b
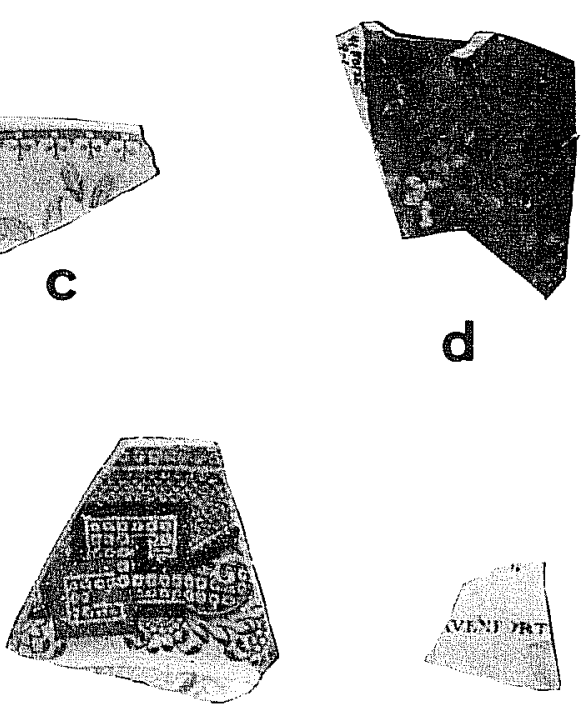

g

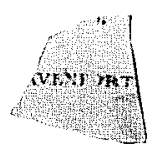

h
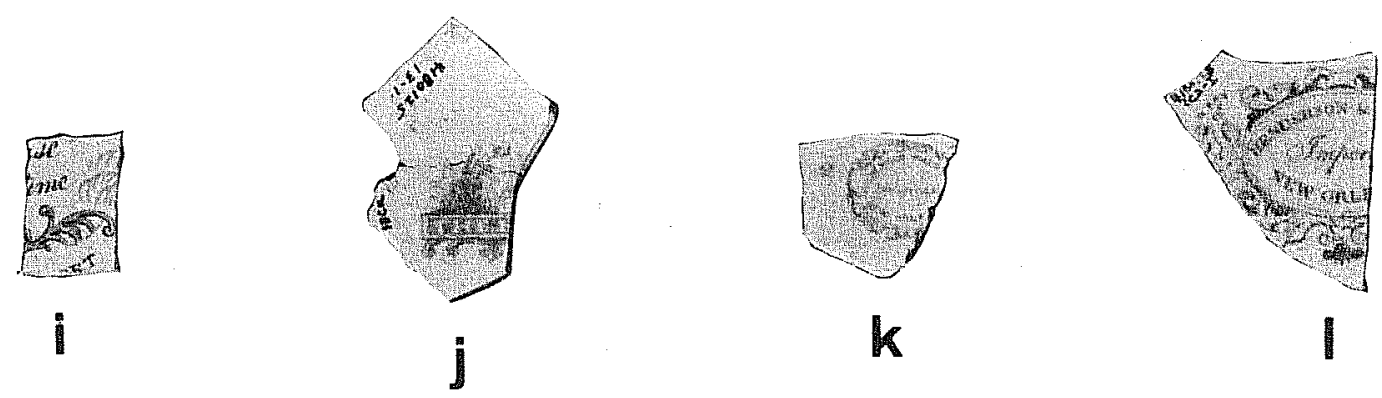

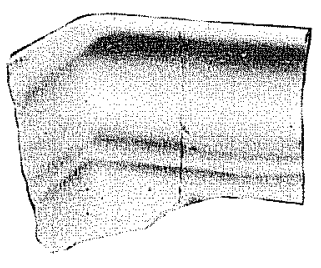

m

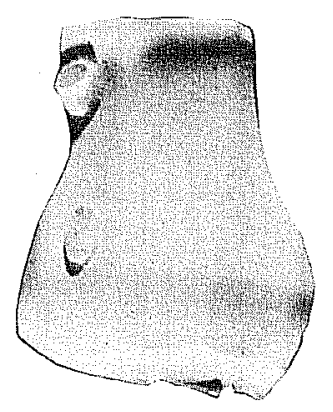

n
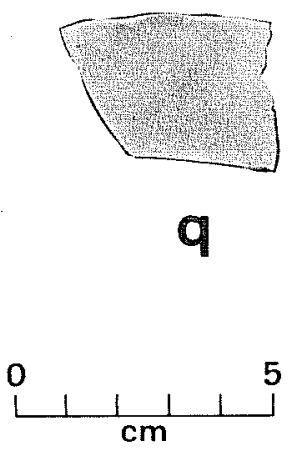

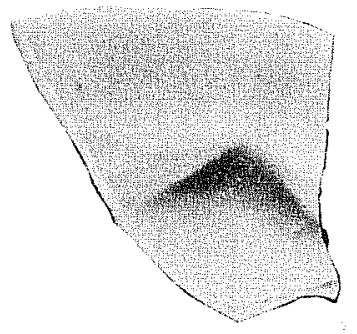

0

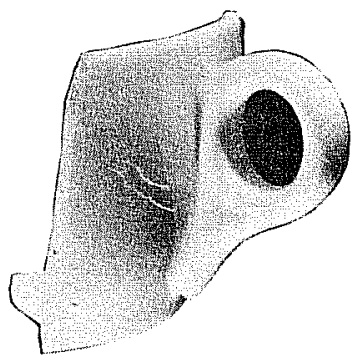

$r$

$p$

5 
TABLE 2

ARTIFACT PROVENIENCE

Freeport Harbor Project

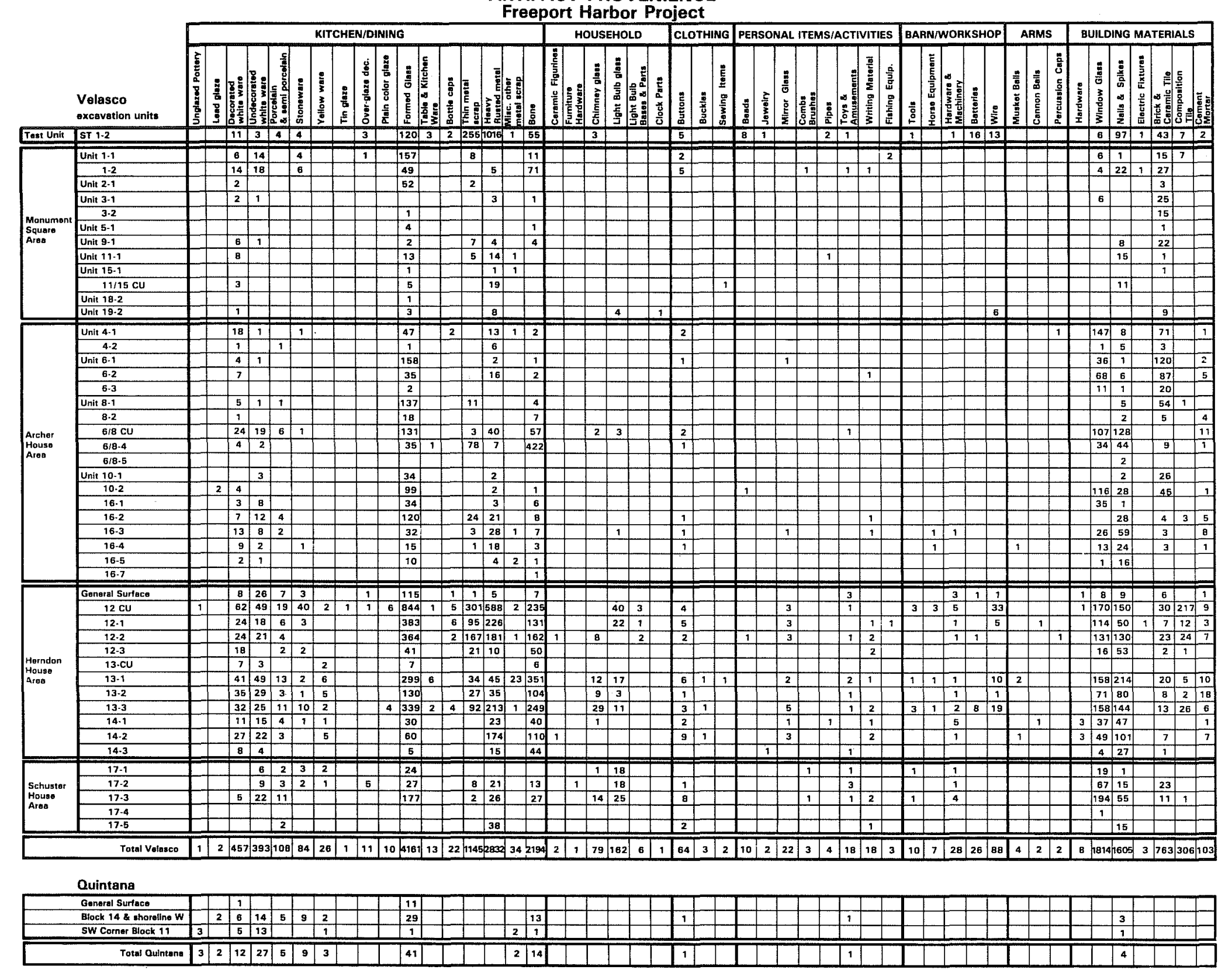


floral patterns appear to be later versions of the original varieties, and may even be American-made (Fig. 13,d,e,f). Banded slipwares include blue and brown-banded vessels, slip-trailed and mocha patterns in shades of blue, tan, and brown. Sponged decoration was found on only two sherds, these being in the Pollan collection from the FVRA excavations. Transfer patterns, the most numerous type of decoration, were found in shades of blue, brown, black, red, purple, and green. Of these, the blue appears to have been the most popular color. This is the only ware upon which were found maker's marks (Fig. 14,h,i). Several patterns in blue and red carried an importer's mark for Henderson, Walton and Company of New Orleans (Fig. 14,1). Freeman (1980:30) reports that John S. Menefee of Texana had business dealings with this firm in 1835-1836.

Undecorated whitewares: Includes undecorated portions of decorated whiteware vessels and ironstone or graniteware. The latter rapidly took the place of transfer decorated whitewares ca. 1850 (Miller 1980:4) on the eastern seaboard, and had almost completely taken the place of decorated earthenwares in Texas by the end of the Civil War. Examples of late 19th century molded ironstone vessel sherds are illustrated in Figure $14, m, n, 0$. A molded maker's mark from the base of an ironstone plate can be dated to May 31, 1858. Sixteen sherds in this group are from heavy plates and cups attributable to the U.S. Coast Guard (Fig. $14, p)$. Also included are a few sherds of cheap, early 20th century white earthenwares, common on farmhouse tables at that time and still available on the market today (Fig. 14, q,r).

Porcelain: Plain, white sherds from delicate cups and saucers. Also included are sherds of two ivory cups and a plate which have a delicate, hand-painted design in red and green and a dinner plate with two blue painted, overglaze stripes around the rim.

Stoneware: Represented are jugs, churns and jars with salt or Bristol glaze. The salt-glazed vessels have Albany slip on the interior and several have traces of blue decoration. One jug lined with a Bristol glaze is unglazed on the outside. Also included in this category are sherds of Scottish-made stoneware bottles, ceramic gin jugs and stoneware ink bottles. Refined, red-bodied stonewares include one sherd from a molded, black luster teapot with hand-painted pink and gold overglaze decoration, and three sherds from a copper luster vessel which had appliqued flowers.

Yellow wares: Primarily sherds of large mixing bowls available in great quantity from mail-order houses around the turn of the century. A1so included are five small sherds from vessels with Rockingham glaze, popular at this time.

Tin glaze: Sometimes called Victorian majolica, an earthenware with naturalistic molded surface decoration. First made in the $1850 \mathrm{~s}$ in England, it was most popular in the United States during the 1880s (Stern 1979:104-105). 
Overglaze decorated wares: Includes both earthenware and porcelain with gold-painted or decalcomania decoration applied over the glaze. The forms and patterns present a11 represent post-1900 vessels.

Plain color glaze: Popular from ca. 1920 to the present, vessels with plain green or rose-colored glaze on both sides were found in the FVRA backdirt at Unit 12 and at the bottom of Unit 13.

\section{Formed Glass (Tota1 4161 fragments)}

In sites where deposits are comparatively undisturbed, glass bottles can be useful for establishing or confirming dates of deposition. In the case of Velasco, the presence of clearly recognizable contemporary bottle sherds in the lowest levels was an aid in confirming the amount of disturbance on the site. Despite the large number of glass container fragments recovered, very few whole bottles survived. Of these, certain ones of special interest have been chosen for discussion and illustration (Fig. 15). Also illustrated are datable fragments from various time periods to demonstrate the variety included in the collection (Fig. 13).

Also included in this category were a relatively small group of sherds from pressed glass objects (Fig. 16,a). Where shapes were identifiable, these were primarily from tumblers and stemmed goblets of mid to late 19th century manufacture. A few pieces of contemporary, dime store vessels are also present (Fig. 13,K). One wine glass fragment (Fig. 16,d), closely resembles early 19th century workmanship. It is nearly identical to one recovered from excavations in Alamo Plaza (Fox, Bass, and Hester 1976:Fig. 23,b) and dated by Nöe1 Hume (1969:190) to the 1815-1830 period.

\section{Table and Kitchen Metalwares (Total 13 objects)}

There are comparatively few identifiable objects in this category. Most of them are illustrated in Figure 16. This probably is more indicative of the poor state of preservation of the metal on the site, than of the actual numbers which are present. It may also be that metal objects such as tableware were less likely to be broken and/or discarded, especially in the early 19th century when they were not as common as in later times. The author has noted this same scarcity on other 19th century sites in Texas (see Fox and Livingston 1979:62; Hudson, Lynn, and Scurlock 1974:74; Fox et al. 1974:Appendix 12).

Bottle caps: This category includes both crown caps and screw-on caps. Since the crown bottle cap was invented in 1892 (Kendrick 1966:49), and the screw-on cap some time later, these indicate post-1900-deposited materials. 
Thin metal scrap: Included in this group are all identifiable fragments of tin cans and other similar containers, plus any metal fragment which appears thin enough (under $2 \mathrm{~mm}$ ) to be part of such an object. Most of the identifiable cans were so badly rusted as to make analysis of the method of manufacture impossible.

Heavy-rusted metal: Most of the metal recovered from this project was too heavily rusted to be identifiable. Objects which are identified have been included in their proper categories, and the remainder make up this group.

Miscellaneous-other metal scrap: This is primarily unidentifiable fragments of thin metal other than iron. Some appear to be portions of pots and pans or other kitchenware. Included are fragments of lead, copper or brass, and aluminum.

\section{Animal Bone}

The following faunal list is arranged in order of frequency of appearance in the excavations.

$\begin{array}{ll}\text { Cow } & \text { Bas sp. } \\ \text { Sheep/goat } & \text { Ovis sp./Capra sp. } \\ \text { Fish } & \text { unidentified } \\ \text { Bird } & \text { unidentified } \\ \text { Chicken } & \text { Gallus gallus } \\ \text { Pig } & \text { Sus scrofa } \\ \text { Rodent } & \text { Sigmodon hispidus } \\ \text { Crab } & \text { unidentified } \\ \text { Snake } & \text { unidentified } \\ \text { Opossum } & \text { Didelphis marsupialis }\end{array}$

The cow bones, predominantly saw-cut, were by far the most numerous, and were found in every excavation unit.

Household Items

These items are commonly found in other areas of the house as well as the kitchen, and can be more directly related to other aspects of home life than food preparation and consumption.

Ceramic Figurines: Two fragments of figurines such as Victorian mantle piece decorations, were recovered from the second level of Units 12 and 14. The pieces were too small for further identification. 
Figure 15. Dark Green Bottles and Whole Bottles.

a. "Black" glass, hand-formed neck and lip, early 19th century (Kendrick 1966:33) (13 CU**)

b. Seal from wine bottle, "LAFITTE/MEDOC" (13-3*)

c. Wine bottle neck, sheared lip, laid on ring, before 1840 (ibid.:48) (6/8 CU)

d. Wine bottle base, 1/4-inch kick up, pontil mark, before 1840 (Kendrick 1966) (12 CU)

e. Wine bottle neck, sheared 1ip, laid on ring, before 1840 (ibid.) (surface, shoreline west of Coast Guard Station)

f. LUNDIN'S CONDENSED JUNIPER-ADE/MAKES 5 GALLONS OF A HEALTHFUL BEVERAGE/ LUNDIN'S KONDENSERADE ENBARS SYRUP/LUNDIN AND COMPANY SOLE MANUFACTURERS CHICAGO, ILL. U.S.A. Aqua, hand-formed Tip, ca. 1880 (Kendrick 1966:22) (17-1)

g. UDOLPHOWOLFE'S/AROMATIC SCHNAPPS/SCHIEDAM. Dark green, hand-formed Tip, popular during Civil War period (Switzer 1974:36, Fig. 49) $(14-2)$

*Numbers in parentheses refer to unit and level within the unit where artifact was found.

**Clean up (CU) indicates artifacts found during clean up of units after tropical storm of November 14-15, 1981. 

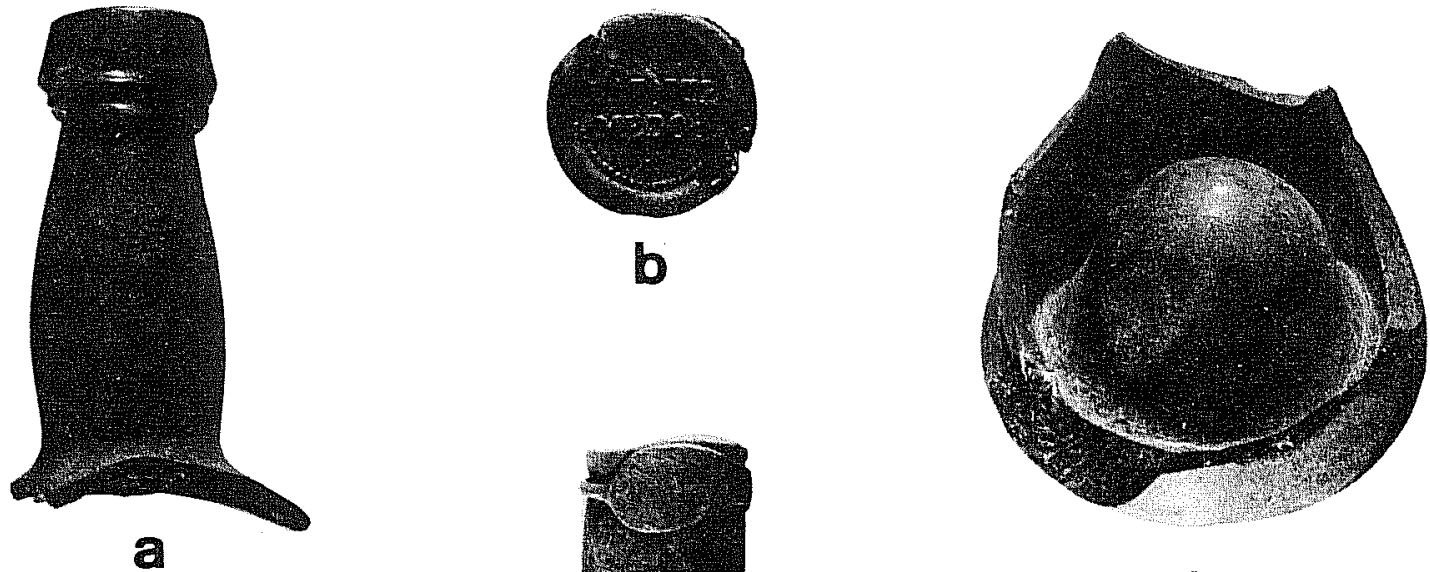

d
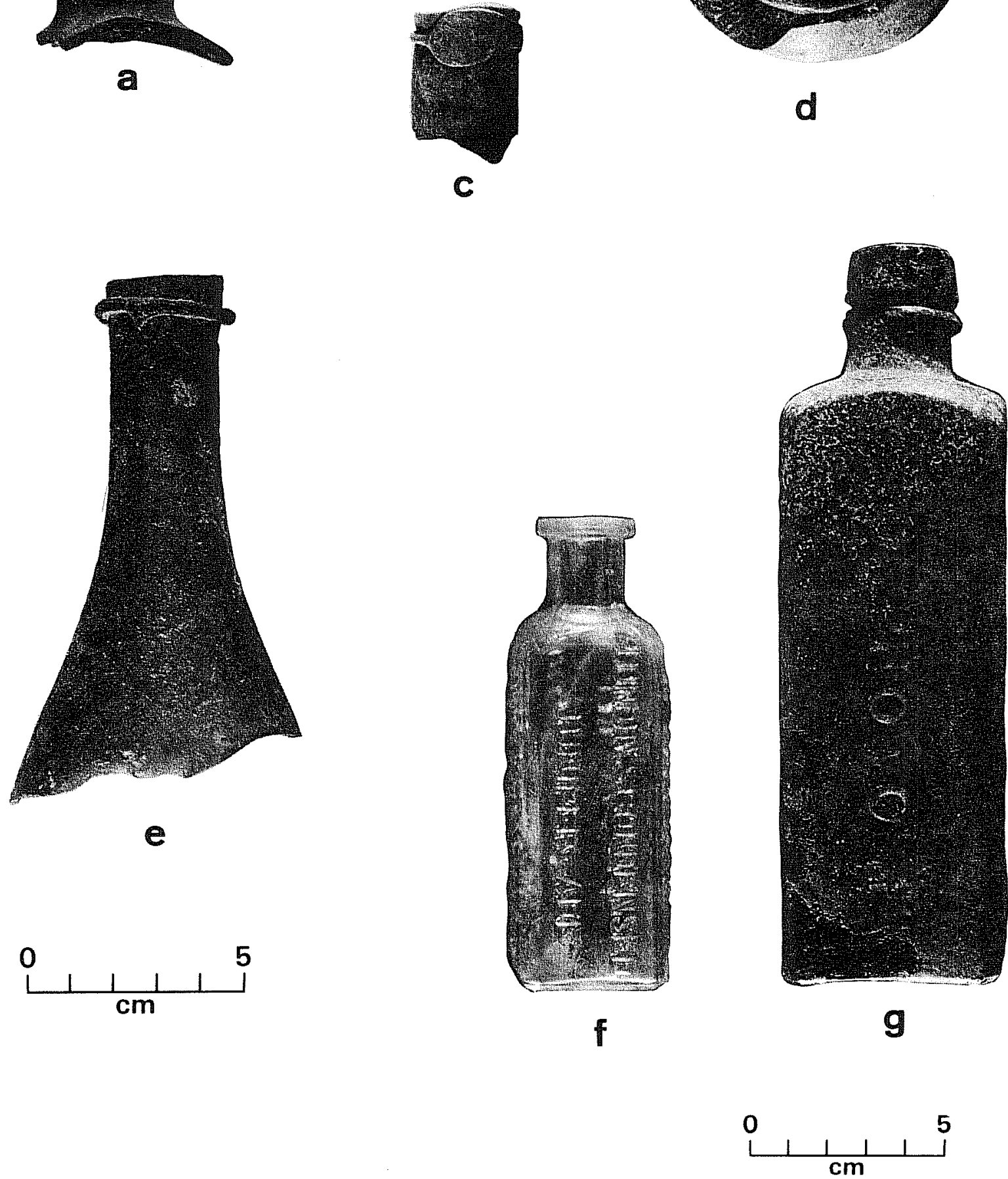

Figure 15. Dark Green Bottles and Whole Bottles. 
Figure 16. Pressed Glass, Table and Kitchenwares, Barn/Workshop Items.

a. Weathered glass, sharp edges on design elements, slight irregularities in design, mid-19th century covered jar or bow $\left(6 / 8 \mathrm{CU}{ }^{\star *}\right)$

b. Weathered glass handle, probably for creamer or sugar bow1 (14-1*)

c. Weathered glass, fragment of unidentifed object (13-1)

d. Weathered glass, fluted wine glass, could be early 19th century (Nöe1 Hume 1969:Figure 64 XXV) (4-1)

e. Clear glass, fluted tumbler with impressed design in base, probably late 19th century

f. Weathered glass, heavy fluted tumbler, irregular basal indentation, probably mid-19th century

g. Bone handle fragment, 19th century (13-1)

h. Bone handle fragment, 19th century (13-1)

i. Knife, appears to be similar to cheap butcher knife type blade popular on the frontier throughout the early and mid-19th century (Russe11 1967:184-185) (13-1)

j. Fork fragment, four tines, probab7y 19th century (6/8-4)

k. Spoon handle, iron with remnant of silver plating (ST 1-2)

1. Kitchen utensil handle, contemporary (12 CU)

m. Fragment of a file (13-3)

n. Bridle rosette (12 CU)

o. Copper rivet for joining leather (13-1)

p. Harness buckle fragment (16-3)

*Numbers in parentheses refer to unit and level within the unit where artifact was found.

**Clean up (CU) indicates artifacts found during clean up of units after tropical storm of November 14-15, 1981. 


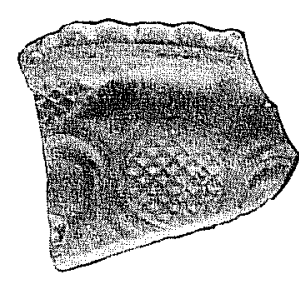

a

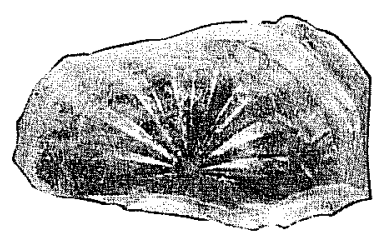

둥

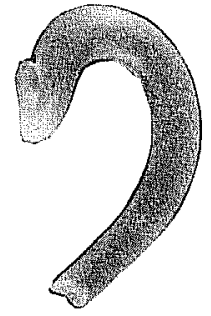

b

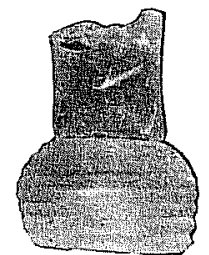

c

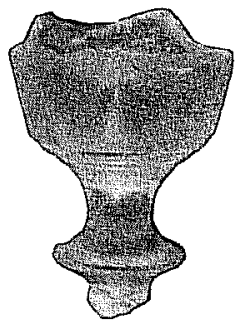

d
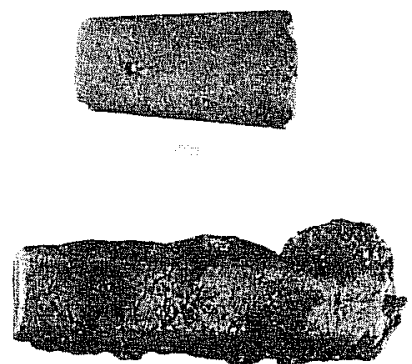

h

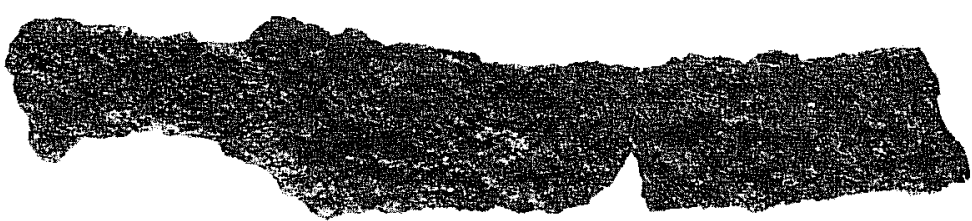

i
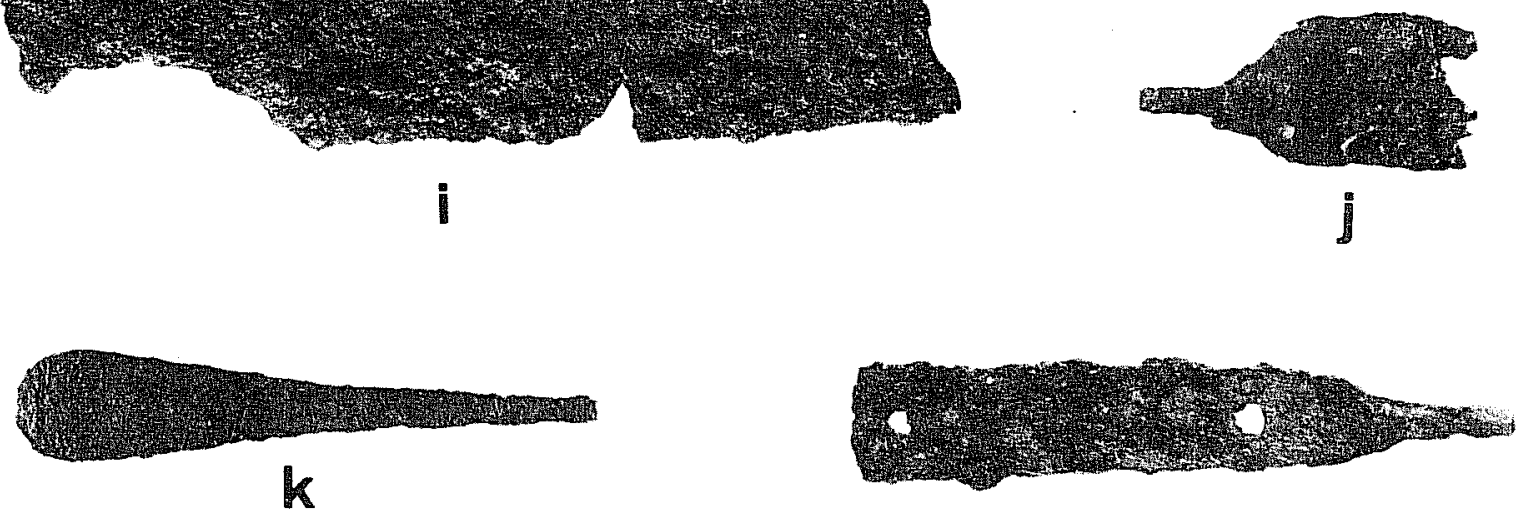

I

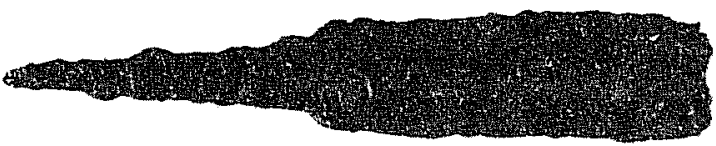

m

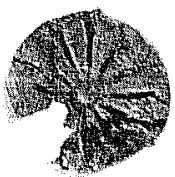

n

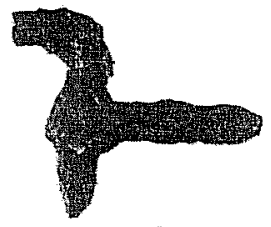

0

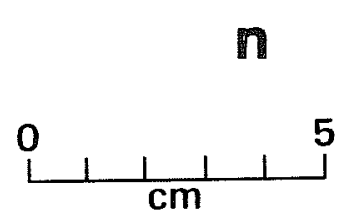

Figure 16. Pressed Glass, Table and Kitchenwares, Barn/Workshop Items. 
Furniture Hardware: An object which is either a brass drawer pull knob or part of a lamp (Fig. 17,a) was the only piece of furniture hardware identified from the collection.

Chimney-Lamp Glass and Light Bulb Glass: An arbitrary separation was made in all thin glass fragments at $T \mathrm{~mm}$. All glass under this thickness was considered to be 1ight bulb fragments, based on measurement of recovered 1ight bulb bases with glass still attached. All relatively thin glass sherds over this thickness (ca. $1 \mathrm{~mm}$ to $2 \mathrm{~mm}$ ) were considered to be lamp glass chimney fragments. Of course, a number were from identifiable portions such as top and bottom rims of chimneys.

Light Bulb Bases: A11 bases recovered were from Unit 12, and were made in the same manner (Fig. 17, bb).

Clock Part: One fragment of the workings of a clock (Fig. 17,z) was recovered from Unit 19.

Personal Items and Activities

Buttons: Buttons of bone, metal, she11, and glass were recovered from the excavations (Fig. 17). There were three bone buttons, all with five holes, one faceted jet button, and five metal ones of various types. of the remainder, twice as many were white glass as were shel1. The majority of these were $1 \mathrm{~cm}$ or less in diameter. Of particular interest is a cast brass military button with slightly raised rim around the face and a cast and drilled shank (Fig. 17,g). This may possibly date to the Spanish occupation period, as the author has observed similarly made buttons from post-1900 Spanish contexts in the San Antonio area. A plain gilded metal button with maker's mark on the back and a stamped metal button with label on the face are also of interest (Fig. 17,f,h).

Buckles: Broken pieces of three small clothing type buckles were found. One (Fig. 17,i) is small enough to be from a watch band or some other type of strap. The others are too fragmented to determine their full size.

Sewing Items: Two brass thimbles ( $F i g .17, j, k$ ) were the only sewing items recovered. One is adult size, the other probably for a child.

Beads: Eleven beads were found. One, of black glass, is illustrated in Figure 17, $n$. Another is identifiable as Harris and Harris (1967:151) No. 132, a "large, milk glass, translucent, barrel-shaped necklace bead of compound, faceted construction." How this bead came to be on the 
site is an interesting question, since such beads were primarily imported for the Indian trade. It was found in level 2 of Unit 10. The remaining 8 beads are scarlet, plastic beads of contemporary design.

Jewelry: A gold-plated pin bearing the U.S. Coast Guard emblem (Fig. 17,0) was the only piece of jewelry recovered.

Mirror glass: A total of 22 pieces of flat glass bore traces of silver coating on one face. They came primarily from Units 12, 13, and 14.

Comb Gragments: Three teeth from black composition combs were found. These were popular in the 1ate 19th century and into the first quarter of the 20th century, and fragments are common on sites of this period.

Pipes: Fragments of two different types of kaolin pipe stems

(Figs. 17,p,q) were recovered from shovel test 1 and Unit 11. A fragment of a molded clay pipe body (Fig. 17,r) was found in Unit 14. Pipes of identical design have been found in 19th century deposits at Missions San Juan Capistrano (Schuetz 1969:P1ate 19Q) and Espiritu Santo at Goliad (personal observation) and two with very similar detail were excavated at Fort Union (1863-1891) by Rex Wi1son (1966:38).

Toys and amusements: Six fragments of porcelain toy tea sets were found. Four were undecorated, one teapot fragment had gold luster decoration with a green enamel overglaze stripe around the base, and one had a blue transfer willow pattern. Additional pieces of this latter tea set are included in the Pollan collection, excavated nearby.

Three porcelain do11 fragments came from Unit 17. They were a11 apparently from different dol1s. A portion of a bisque head is illustrated in Figure 17, $v$.

One black and one white glass, one yellow-glazed and two unglazed clay marbles came from the excavations. An unusual find is a stone marble $3 \mathrm{~cm}$ in diameter (Fig. 17,t). A portion of the bone or ivory of a domino (Fig. 17,w) was found in Unit 14.

Two fragments of metal cap pistols complete the toy collection. These are both of comparatively recent vintage.

An interesting item found is a token good for one ride on the "Austin City R...." probably the trolley line which began operation ca. 1874 (Austin Public Library, personal communication). It is made of an orange composition material which probably dates it to the late 19th century ( $\mathrm{Fig}, 17, \mathrm{~s}$ ). 
Figure 17. Construction, Arms, Clothing, Personal and Household Items.
a. Door knob spindle (14-1*)
o. U.S. Coast Guard pin (ST 1-2)
b. Ceramic door knob fragment (12 CU**)
p. Kaolin pipe stem fragment (11-1)
C. Percussion caps (4-1 and 12-2)
q. Kaol in pipe stem fragment (ST 1-2)
d,e. Bone buttons (12 CU and 13-3)
r. Molded clay pipe (14-1)
f. Plain, gilded military button, marked "ORANGE/LONDON/EXTRA FINE," 1800-1850 (Schuetz 1969:41-42) (13-1)
s. Trolley line token, "AUSTIN CITY R ..." $(17-3)$
g. Simple metal button with cast, drilled
t. Limestone marble, made in Germany up to 1900 (Block 1979:152) (6/8 CU) shank ca. $1800(12-1)$
h. Work clothes button, post-1855 (ibid.:40)
u. Opaque white glass marble, ca. 1900 (ibid.: 156) (13-1) (surface Quintana shoreline)
i. Smal1 metal buckle (13-1)
j. Child's thimble (13-1)
k. Adult size thimble (11/15 CU)
1. Shel1 button (13-3)
m. White glass button (4-1)
n. Black glass bead, probably late 19th
v. Bisque doll's head (17-3)
w. Bone or ivory domino face (14-3)
$x, y$ Lead fishing weights (1-1)
z. Clock part (19-2)
aa. Brass drawer pull or part of a lamp (17-2)
bb. Light butb (12-2) century (12-2)

*Numbers in parentheses refer to unit and level within the unit where artifact was found.

**Clean up (CU) indicates artifacts found during clean up of units after tropical storm of November $14-15,1981$. 


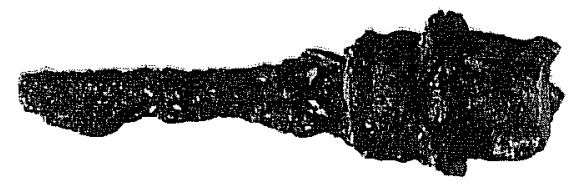

a
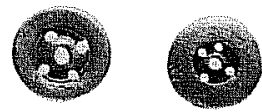

d

(c)

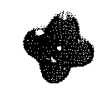

k I

m

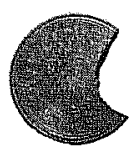

$r$

q
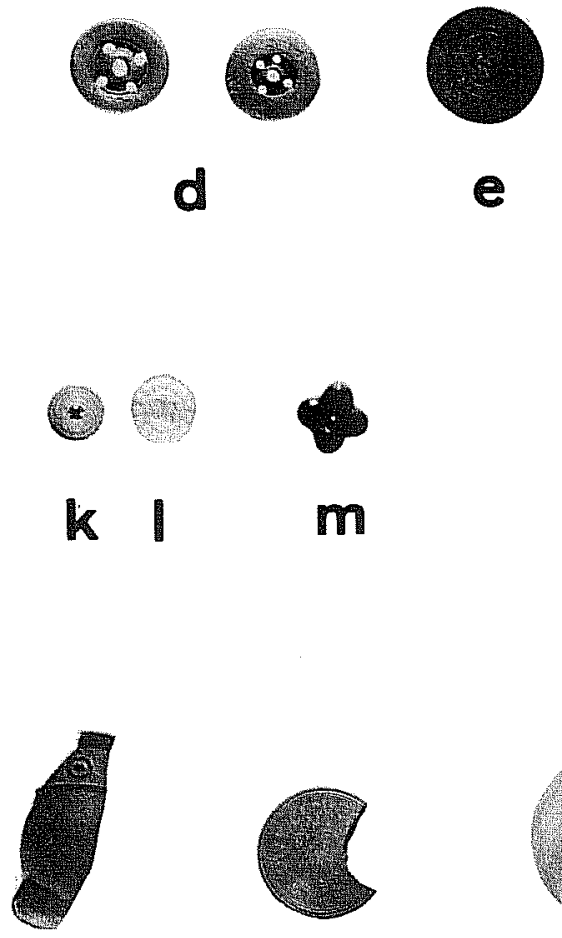

e

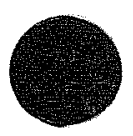

f

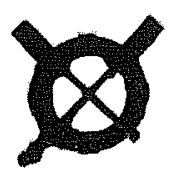

n

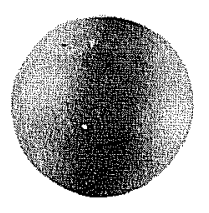

s

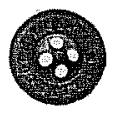

g

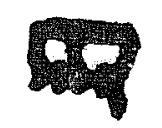

h

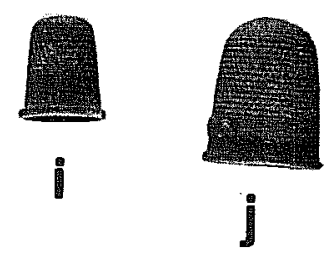

forsters

o

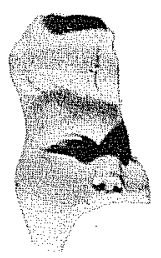

u

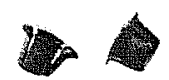

c

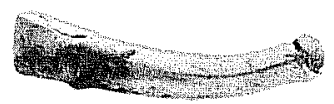

p
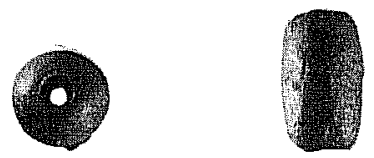

$w$

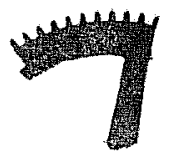

$x$

$y$

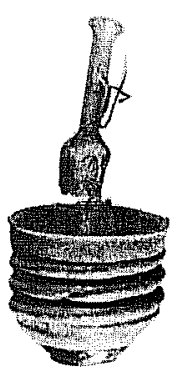

$z$

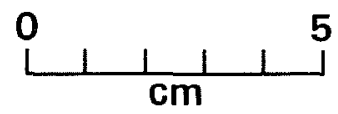

Figure 17. Construction, Arms, Clothing, Personal and Household Items. 
Writing Material: Fragments of slate and slate pencils were found in nearly every section of the town site, representing a common method of writing during the middle to late 19th century. A pencil lead fragment and an eraser holder from a wooden pencil from more recent times were also present.

Fishing Equipment: As might be expected in such a setting, lead sinkers (Fig. 17, $x, y$ ) and a fish hook were also found in the site.

\section{Barn/Workshop}

Tools: A whole bit brace and a portion of a flat file (Fig. 16,m) were the only positively identifiable tools recovered from the excavations. There are also fragments which are probably parts of other tools and are tentatively identified as such.

Horse Equipment: Included in this category are a partial horseshoe, a bridle rosette, a rivet for fastening leather, two D-rings which may have come from a saddle, and a partial harness buckle (Fig. 16,p). Other badly rusted fragments may also be bridle and saddle parts.

Hardware: Fragments of wagon hardware and a number of heavy bolts, gears, a rubber whee 1, a fragment of a machinery belt, a handful of heavy grommets, and a spark plug are included in this category.

Batteries: Numerous fragments of carbon battery cores which range from $8 \mathrm{~mm}$ to $27 \mathrm{~mm}$ in diameter were found in Test Pit No. 1, and Units 12 and 13.

Arms

Lead balls of the following dimensions were found:
Unit 15-1
$6 \mathrm{~mm}$ diameter (3 grams)
Unit 16-4
$8 \mathrm{~mm}$ diameter ( 4.5 grams)
Unit 13-1
$8 \mathrm{~mm}$ diameter (4.8 grams)
Unit 14-2
$10 \mathrm{~mm}$ diameter (10.5 grams)

A fragment of lead sprue was found in Unit 16, level 3. Two percussion caps (Fig. 17, C) and two iron cannon balls probably represent the Civil War defenses in the area. Similar objects evidently were excavated in this area by the Fort Velasco Restoration Association in 1971. 
Building Materials

Hardware: Among the identifiable fragments of building hardware were pieces of a late 19th century door lock and a ceramic knob from Units 12 and 14 (Fig. 17,a,b).

Window Glass: A total of 1814 window glass fragments were recovered from all areas of the site. They measure from $1 \mathrm{~mm}$ to $2 \mathrm{~mm}$ in thickness.

Nails, Spikes, Etc.: Nails recovered from the excavations were in such bad condition that it was impossible to determine, in most cases, what their original shape or size had been. Two large spikes and a modern toggle bolt were also recovered. In all, 1605 nails and spikes were recovered.

Electric Fixtures: Fragments of porcelain electric fixtures and a porcelain insulator were found in shovel test 1 , and Units 1 and 12. Some of the wire fragments present may also be related to electric fixtures.

Brick and Ceramic Tile: By far the majority of the brick recovered from the test excavations was a soft, sandy, locally made type referred to in the area as "plantation brick" (H. B. Fearn, personal communication). It was made by hand in the early to mid-19th century in wooden molds and fired in kilns built of the same brick (see Fox, Day, and Highley 1980: Appendix I, 181-188). Individual bricks varied quite a bit in size and color, depending on the whim of the local brickmaker and the placement of an individual brick within the kiln. However, they average $3-3 / 8$ to 3-5/8 inches wide and 2 inches thick, and most are gray to red-orange in color, some bearing traces of a salt glaze. No whole bricks were recovered from which to reconstruct the average length. Bricks found on the surface at the Schuster house were probably made after 1900. One is a yellow fire brick with the impressed mark, GINGER. The other type is a red-brown, high-fired type bearing the impressed mark, ANDY CORDELL REDS. Both of these types were used in constructing a fireplace and chimney in the present house, at some time after the house itself was built, which would date them sometime in the early 20 th century.

Contemporary Composition Tile and Cement Mortar: Fragments of both of these materials were recovered from nearly every unit and from various depths, again indicating the disturbed state of the deposits. 


\section{SUMMARY STATEMENT}

The most obvious characteristic of the sites of Velasco and Quintana are their nearly complete lack of any structural traces predating about 1900. We cannot be sure how close the units were placed relative to the various buildings of Velasco as of ca. 1850, but many should have been fairly close to some structures. The stratigraphy, such as it is, indicates virtually no occupation surface earlier than 1880-1900. What happened to the town and the fort?

We can only assume that the rather startling number of severe hurricanes which swept this coast, frequently sending the ocean across the site at depths of 10-15 feet, scoured most of the traces of the town from the soil. Added to this is the severe damage done to Velasco by street building, drainage, and other large surface modifications, and the destruction of most of the warehouse district of Quintana by changes to the river channel and construction of docking facilities. Based on the evidence of the history of the sites, the maps, and the archaeology, we are left to conclude that there are virtually no surviving structural remains of old Velasco and very little of old Quintana.

The one place where an early house site seems to have survived in some form is in an area protected by a massive clump of salt cedars (Units 3 , 7, 2, 11, and 15; Fig. 8). Although the artifact collection from this structural trace is very small, it still suggests a date for the structure of ca. 1830-1840. The structure was probably burned. Its location within Monument Square, the general site of the Mexican Fort Velasco and associated structures, where no later structures are known to have existed, leads us to believe that this may have been the site of one of the buildings burned by Ugartechea in June 1832 as preparation for the Battle of Velasco. The Anglo nature of the few artifacts argues for the possibility that this was a building associated with Asa Mitche11's home or enterprises. The very high ground water level (most of the area was standing in 2-3 inches of water during the excavation) prevented any further exploration of this structure, so that the extent of the remains or the existence of other traces of structure in the area cannot be determined. If these structural remains are what they seem--that is, a portion of a house burned during the battle of 1832--then it is possible that subsurface traces of the foundations of other buildings and Fort Velasco itself may also survive.

The nearly complete disappearance of archaeological traces is a relatively unusual event. Sites are rarely totally obliterated by any combination of the actions of man and nature. However, the characteristics of the artifact distribution, where a mixture of 1850s through 1930s artifacts are randomly deposited almost invariably in close relationship to substantial masonry remains such as chimney bases and brick foundations, in direct violation of the standard Anglo pattern of trash dumps at doors and windows (see Stanley South 1977:48 for a discussion of this) can best be explained by hurricane destruction of the site, unsatisfying though this is. The more extensive survival of mid19th century structural traces on the Quintana side of the river as found by Warren Lynn is probably attributable to the dense brown clay 
which forms the subsoil here. Such a subsoil would seem to be much less susceptible to the effects of storm tides and scouring. The almost pure sand subsoil of old Velasco offered no such resistance to these tides. 


\section{RECOMMENDATIONS}

In order to be considered eligible for nomination to the National Register of Historic Places, a historic site must be over 50 years old, have integrity of location, design, setting, material, workmanship, feeling and association. It must also be associated with significant historic events or individuals, embody distinctive architectural characteristics, or be likely to yield important historic information. Using these criteria, on the basis of historic research alone, it would seem that the entire area at the mouth of the Brazos River should qualify for nomination. However, it now appears that this may not be an accurate as ses sment.

On the basis of our investigations, we believe that all significant historical structures of the town of Quintana have been destroyed by channel widening and erosion, and that, therefore, the site should not be considered eligible for nomination. We feel that traces of the structures of the town of Velasco and all related cultural deposits which would be necessary for their identification and interpretation have been virtually eradicated by storm action, making it also ineligible. The gun emplacements near the Quintana shoreline are clearly less than 50 years old, and therefore automatically ineligible.

Judging from the survival of early 19th century subsurface remains in the Monument Square area, we suggest that it is entirely possible that the patterns of post molds and fortification ditches of Fort Velasco as constructed by Colonel Ugartechea may still remain in the subsoil, despite the fact that the original, artifact bearing surface has been destroyed.

In order to verify the existence of the traces of Fort Velasco, it would be necessary to remove 4 inches of sandy overburden over a relatively large area (ca. $350 \times 400 \mathrm{ft}$ ). If done carefully during a relatively dry season of the year, we believe mechanical means could be used without injuring the structural remains. When the overburden has been removed, hand-shaving with flat shovels should fairly quickly reveal any remaining structural evidence. This evidence should consist of two concentric circles of post stains, the outer one with a diameter of ca. $60 \mathrm{ft}$ and the inner one with a diameter of ca. $20 \mathrm{ft}$. There may possibly also be a third circle $6 \mathrm{ft}$ inside the outer one. Immediately outside the outer circle of post stains there may be found a defensive ditch at least $6 \mathrm{ft}$. wide and perhaps $3 \mathrm{ft}$ deep (see Ugartechea 1832d: 3, 4; Looscan 1897:283; Smith 1911:38, 41). Other buildings present in this area (Fig. 4) would have left traces similar to those found in Units $3,7,9,11$, and 15 (Fig. 8). If the remains of the fort are found to survive, at this point the possibility of its nomination to the National Register of Historic Places should be further examined. 


\section{REFERENCES CITED}

Almonte, Colonel Juan $\mathrm{N}$.

1925 Statistical Report on Texas. Southwestern Historical Quarterly XVIII:177-222.

Bacarisse, C. A.

1953 The Texas Gazette, 1829-1831. Southwestern Historical quarterey LVI:239-253.

Bailey, J. B.

1832 Letter to David Shelby, June 27, 1832. BTake Papers Supplement 62:194-195.

Barker, E. C.

1969 The Life of Stephen F. Austin, Founder of Texas, 1793-1836. Cokesbury Press 1926. Reprinted University of Texas Press, Austin.

Barr, A.

1961 Texas Coastal Defense, 1861-1865. Southwestern Historical quarterly XLV:1-31.

Bass, F. A., Jr. and B. R. Brunson

1978 Fragile Empires. The Texas Correspondence of Samuel Swartwout and James Morgan, 1836-1856. Shoal Creek Publishers, Austin.

Beacroft, P. T., Jr.

1980 Letter to Mr. Truett Latimer, Executive Director, Texas - Historical Commission, July 29, 1980.

Bertleth, R. G.

1917 Jared Ellison Groce. Southwestern Historical Quarterly $X X: 358-368$.

Block, S.

1979 Marbles, Playing for Fun and for Keeps. In The Encyclopedia of Collectibles; Lalique to Marbles. Time-Life Books, Alexandria, Virginia. 
Bolton, H. E.

1970 Texas in the Middle Eighteenth Century. University of California Publications in History, Vol. 3. Original Printing, 1915. Reprinted University of Texas Press, Austin.

Bond, C. L.

1980 A Cultural Resources Assessment of Selected Magnetic Anomalies, Freeport Harbor, Texas 45-Foot Project. Ervin Garrison, Principal Investigator.

Bradburn, Colonel $\mathrm{J}$.

1832 Letter to Colonel Antonio Elosua, April 4, 1832. Bexar Archives Microfilm Rol1 149:119.

Branda, E. S., ed.

1976 The Handbook of Texas, A Supplement, Vol. III. Texas State Historical Association, Austin, Texas.

Brazoria County Women's Clubs

m.s. History of Brazoria County. Manuscript on file, Brazoria County Library, Angleton, Texas.

Bryan, J. P., ed.

1965 Mary Austin Holley. University of Texas Press, Austin.

Coast Guardsmen of the Freeport Lifeboat Station

1960 Station Dates Back to 1887. Brazosport Facts. March 6, 1960.

Creighton, J. A.

1975 A Narrative History of Brazoria County. Brazoria County Historical Commission. Texian Press, Waco, Texas.

Curlee, A.

1923 The History of a Texas Slave Plantation, 1831-1863. Southwestern Historical Quarterly XXVI:79-127.

Davis, E. M. and J. E. Corbin

1967 Archaeological Investigations at Washington on the Brazos State Park in 1966. State Building Commission Aichaeological Program, Report 5. 
Encyclopaedia Britannica

1911 Life-Boat, and Life-Saving Service. 11th Edition. University Press, Cambridge.

Erath, L. A.

1923 Memoirs of Major George Bernard Erath. Southwestern Historical Quarterly XXVI:207-233, 255-280.

Fairfield Industries

1979 Freeport Harbor, Texas 45-Foot Project, Cultural Resources Assessment. Frank Hole, consulting archaeologist.

Farmer, J.

1959 Piñeda's Sketch. Southwestern Historical Quarterly LXIII: 110-114.

Faulk, 0. B.

1964 The Last Years of Spanish Texas, 1778-1821. Mouton and Co., London.

Fehrenbach, T. R.

1968 Lone Star - A History of Texas and the Texans. Macmillan, New York.

Forne11, E. W.

1961 The Galveston Era - The Texas Crescent on the Eve of Secession. University of Texas Press, Austin.

Fox, A. A.

1981 An Architectural and Historical Assessment of the Freeport Lifeboat Station of the U.S. Coast Guard at Surfside, Texas. Manuscript on file at Center for Archaeological Research, The University of Texas at San Antonio.

Fox, A. A., F. A. Bass, Jr., and T. R. Hester

1976 The Archaeology and History of Alamo Plaza. Center for Archaeological Research. The University of Texas at San Antonio, Archaeological Survey Report 16.

Fox, A. A., D. W. Day, and L. Hightey

1980 Archaeological and Historical Investigations at Wallisville Lake, Chambers and Liberty Counties, Texas. Center for Archaeological Research. The University of Texas at San Antonio, Archaeological Survey Report 90. 
Fox, A. A. and K. Livingston

1979 Architectural and Archaeological Investigations at the Steiner-Schob Complex, Coleto Creek, Victoria, Texas. Center for Archaeological Research. The University of Texas at San Antonio, Archaeological Survey Report 52.

Fox, D. E., R. T. Mallouf, N. O'Ma17ey, and W. M. Sorrow

1974 Archeological Resources of the Proposed Cuero I Reservoir, DeWitt and Gonzales Counties, Texas. Texas Historical Commission and Texas Water Development Board, Archeological Survey Report 12.

Freeman, M. D.

1980 The Antebellum Period in the Stephen F. Austin Colony: Historical and Archaeological Research in the Palmetto Bend Reservoir Area, Jackson County, Texas. Part I: The Sutherland Plantation and the Alabama Settlement: A Study in Cluster Migration. Texas Archeological Survey, The University of Texas at Austin. Research Report 70. Palmetto Bend Reservoir Series 5.

Friend, L.

1969 Sam Houston - The Great Designer. University of Texas Press, Austin.

Godden, G. A.

1964 Encyclopaedia of British Pottery and Porcelain Marks. Bonanza Books, New York.

Golden, P. 0., Lieutenant, U.S. Coast Guard

1980 Letter to Anne Fox, Center for Archaeological Research, December 3, 1980.

Goode, Sir John

1890 Brazos River, Texas: Comparative Plans of Entrance at Different Dates (4 maps). Originals in Barker Texas History Center Archives, Austin.

Gray, R. S., ed.

1975 A visit to Texas in 1831, Being the Journal of a Traveller Through Those Parts Most Interesting to American Settlers with Descriptions of Scenery, Habits, Etc. Third Edition. Cordovan Press, Houston. 
Gray, W. F.

1965 The Diary of Colonel William Fairfax Gray, from Virginia to Texas, 1835. The Fletcher Young Publishing Company, Houston.

Green, R. M.

1952 Samuel Maverick, Texan, 1803-1870. Privately Printed by Author, San Antonio.

Gulick, C. A., Jr. and K. Elliott

1921 Papers of Mirabeau Bonaparte Lamar. Texas State Library, Austin.

Haggard, J. V.

1937 Epidemic Cholera in Texas, 1833-1834. Southwestern Historical quarterly XL:216-230.

Hanson, C. E., Jr.

1981 Turlington and Peppermint. The Museum of the Fur Trade Quarterly 17(1):10-11.

Harris, R. K. and I. M. Harris

1967 Trade Beads, Projectile Points, and Knives. In A Pilot Study of Wichita Indian Archaeology and Ethnohistory (assembled by R. E. Be11, E. B. Je1ks, W. W. Newcomb). Southern Methodist University, Dallas. Report to the National Science Foundation:129-162.

Hays, T. R.

1981 Cultural Resource Assessment, Freeport Harbor, Texas 45-Foot Project. Report in progress.

Hester, T. R.

1980 Digging into South Texas Prehistory. Corona Publishing Company, San Antonio.

Hogan, W. R.

1975 The Texas Republic, A Social and Economic History. University of Texas Press, Austin.

Hole, F.

1980 Letter to Anne A. Fox, 13 November. On file at Center for Archaeological Research, The University of Texas at San Antonio. 
Holley, M. A.

1836 Texas. J. Clarke Company, Lexington, Kentucky.

1808-1846 Letters, 1808-1846. Barker Texas History Center, Austin.

Hudson, W. R., Jr., W. M. Lynn, and D. Scurlock

1974 Walker Ranch: An Archeological Reconnaissance and Excavations in Northern Bexar County, Texas. Texas Historical Commission, Office of the State Archeologist, Report 26.

Humphries, Mrs. T. A.

1933 01d Quintana, Texas First Sea Port. The Dallas Morning News, October 15, 1933.

Ippolito, J. E. and E. P. Baxter

1976 An Archeological Survey of the Freeport Harbor 45-Foot Navigation Project, Brazoria County, Texas. Anthropology Laboratory, Texas A\&M University, Report 21.

Jenkins, J. H., ed.

1973 The Papers of the Texas Revolution. Ten Volumes. Presidial Press, Austin.

Johnson, R. and C. C. Buel

1884 Battles and Leaders of the Civil War. Century Press, New York.

Kendrick, G.

1966 The Antique Bottle Collector. Edwards Brothers, Ann Arbor, Michigan.

1967 Bottle Fragments Betray Age of Historical Sites. El Palacio $74(2): 19-24$.

Lewis, W. S.

1899 The Adventures of the "Lively" Immigrants. Quarterly of the Texas State Historical Association III:81-107.

Looscan, A. B.

1897 The 01d Mexican Fort at Velasco. Quarterly of the Texas State Historical Association I:282-284. 
Lukes, E. A.

1976 Dewitt Colony of Texas. Jenkins Publishing Company, The Pemberton Press, Austin.

Lynn, W. M.

1979 Draft Technical Report of Archeological Survey and Excavation on Quintana Island, Texas. Manuscript submitted to the Brazos River Harbor Navigation District. Copy on file at Center for Archaeological Research, The University of Texas at San Antonio.

Malsch, B.

1977 Indianola - The Mother of Western Texas. Shoal Creek Pub1 ishers, Austin.

Mason, H. M., Jr.

1972 Death from the Sea. Dial Press, New York.

Menefee, J. S.

1880 Early Jackson County Settlers. Texana Clarion, June 3, 1880 .

Miller, G. L.

1980 Classification and Economic Scaling of 19th Century Ceramics. Historical Archaeology 14:1-40.

Mullins, M. D., compiler

1959 The First Census of Texas, 1829-1836. National Genealogical Society, Washington, D. C.

Murphy, L. and D. J. Lenihan

1980 A Report on a Two-Day Submerged Cultural Resources Assessment Survey, Freeport Harbor, Texas 45 Foot Project. Letter report by the National Park Service.

Newcomb, W. W., Jr.

1961 The Indians of Texas, from Historic to Modern Times. University of Texas Press, Austin. 
Nichols, R. G.

1953 Samuel May Williams. Southwestern Historical quarterly LVI : 189-210.

Noë1 Hume, I.

1969 Historical Archaeology. Alfred A. Knopf, New York.

Odum Offshore Surveys, Inc.

1978 Report of Survey, Cultural Resources Reconnaissance, Freeport (Texas) Harbor - 45 Foot Project. Jack Hudson, consulting archaeologist.

01 msted, F. L.

1978 A Journey Through Texas. Reprint of 1857 edition. University of Texas Press, Austin.

Pierce, G. S.

1969 Texas Under Arms, the Camps, Posts, Forts and Military Towns of the Republic of Texas, 1836-1846. Encino Press, Austin.

Pratt, W. W., ed.

1954 Galveston Island, or a Few Months off the Coast of Texas, The Journal of Francis C. Sheridan. University of Texas Press, Austin.

Rowley, 0.

1837 Map of Quintana. Brazos County Deed Records 32:6-9.

Russe11, C. P.

1967 Firearms, Traps and Tools of the Mountain Men. Alfred A. Knopf, New York.

Schuetz, M. K.

1969 Description of the Artifacts and Ethnohistory of the Coahuiltecan Indians. The History and Archeology of Mission San Juan Capistrano, San Antonio, Texas II. State Building Commission Archeological Program, Report 11.

Seele, H.

1979 The Cypress, and Other Writings of a German Pioneer in Texas. Translated by Edward C. Breitenkamp. University of Texas Press, Austin. 
Sibley, M. M.

1967 Travelers in Texas 1761-1860. University of Texas Press, Austin.

Smith, $H$.

1911 Reminiscences of Henry Smith. Quarterly of the Texas State Historical Association XIV:24-55.

Smithwick, N.

1900 The Evolution of a State, or Recollections of old Texas Days. Compiled by his daughter, Nanna Smithwick Donaldson. Gammel Book Company, Austin.

South, S.

1977 Method and Theory in Historical Archeology. Academic Press, New York.

Stern, A.

1979 Majolica, Flamboyant Victorian Ware. In The Encyclopedia of Collectibles, Lalique to Marbles. Time-Life Books, Alexandria, Virginia.

Strobridge, T. R.

1972 United States Coast Guard Annotated Bibliography. Department of Transportation, U.S. Coast Guard.

Sturgeon, S. H.

1943 Commerce in the Texas Empressario Colonies. Master's thesis. Northwestern University, Evanston, Illinois. Copy on file at Center for Archaeological Research, The University of Texas at San Antonio.

Switzer, R. R.

1974 The Bertrand Bottles. A Study of 19th Century Glass and Ceramic Containers. National Park Service, United States Department of the Interior. Publications in Archeology 12. Washington, D. C.

Texas Almanac

1974 Texas Almanac and State Industrial Guide. A. H. Be1o Corp., Dallas. 
Toulouse, J. H.

1971 Bottle Makers and Their Marks. Thomas Nelson, Inc., New York.

Ugartechea, Colonel Domingo de

1832a Letter to Colonel Antonio Elosua, March 13, 1832. Bexar Archives Microfilm Rol1 148:602.

1832b Letter to Colonel Antonio Elosua, May 15, 1832. Bexar Archives Microfilm Roll 150:29.

1832c Letter to Colonel Antonio Elosua, June 7, 1832. Bexar Archives Microfilm Rol1 150:621.

1832d Letter to Colonel Antonio Sosua (Elosua), Commander-inChief of the State of Coahuila and Texas, July 1, 1832. Bexar Archives Microfilm Rol1 150:220. Translated by Dora Guerra of the John Peace Library of The University of Texas at San Antonio.

U.S. Army Corps of Engineers

1979 Documentation on Fort Velasco-Quintana Historic District for Determination of Eligibility for Inclusion in National Register of Historic Places. U.S. Army Corps of Engineers, Galveston District. Copy on file at Center for Archaeological Research, The University of Texas at San Antonio.

1980 Contract, Number DACW64-80-C. Document on file with the Center for Archaeological Research, The University of Texas at San Antonio.

United States Coastal Survey

1858 Preliminary Chart of Entrance to Brazos River, Texas. Copy on file with the Center for Archaeological Research, The University of Texas at San Antonio. Original in Texas State Archives.

United States Department of War

1889 The War of the Rebellion - A Compilation of the Official Records of the Union and Confederate Armies, Series I, Vol. XXVI, Part II. U.S. Government Printing Office, Washington, D.C. 
United States Geological Survey

1974 Freeport, Texas Quadrangle, 1:24,000.

Webb, W. P., ed.

1952 The Handbook of Texas. Two Volumes. Texas State Historical Association, Austin.

Williams, J. W.

1979 Old Texas Trails. Edited and Compiled by Kenneth F. Neighbors. Eakin Press, Burnet.

Wilson, R. L.

1966 Tobacco Pipes from Fort Union, New Mexico. El Palacio $73(1): 32-40$. 



\section{APPENDIX I}

\section{ASSESSMENT OF SURFSIDE STRUCTURES}

One of the assigned tasks of the survey crew was to assess the sta;!ling structures in and adjacent to the project area in terms of historic criteria. In obedience to this directive, the author recorded on fillu and in field notes the architectural style, construction, general condition and approximate date of construction of each such structure. A total of 23 structures were recorded. The majority of them (numbers 10 to 22) are comparatively modern beach houses, built well above the ground level on creosoted posts, with composition shingle roofs. This includes all standing structures in blocks 565 through 567 of Surfside townsite. One larger frame home, built closer to the channel than the rest, is a composite of many styles and what looks to be numerous additions. While it is attractive, it does not embody the distinctive characteristics of a type, period, or method of construction, nor to our knowledge has it been associated with events or people of historical significance. Standing structures on blocks 561 through 564 were more superficially examined and found to be essentially of the same types of construction as those in blocks 565 through 567, but not as recently built. Structures 1 through 9 are indicated by number on Figure 8.

1. Called local1y, "The Captain's House" (Fig. 18,a) and apparently built for the husband of the member of the Schuster family mentioned on page 51. Portion to the east: box and strip set on $8 \times 12$-inch squared posts, standard trim, wire nails, shingled hipped roof. Addition to the east: box and strip on creosoted posts, wire nails, composition shed roof. Addition to the west: horizontal siding, set on tall creosoted posts with floor at height of eaves of central structure, flat roof. Condition: Partially collapsed and open to the elements. Age: Earliest section built ca. 1910.

2. Presently a two-story structure with garage below. It was originally one story, and survived the 1932 hurricane. Finally, after Hurricane Carla, it was raised on piers and an addition was put on the back. Condition: good, occupied and well tended. Age: Difficult to tell, but probably after 1900 .

3. One-story, tar paper-covered shack with two shed additions to the rear. Condition: poor, surrounded by trash, junk cars, etc. Age: no way to tell. 


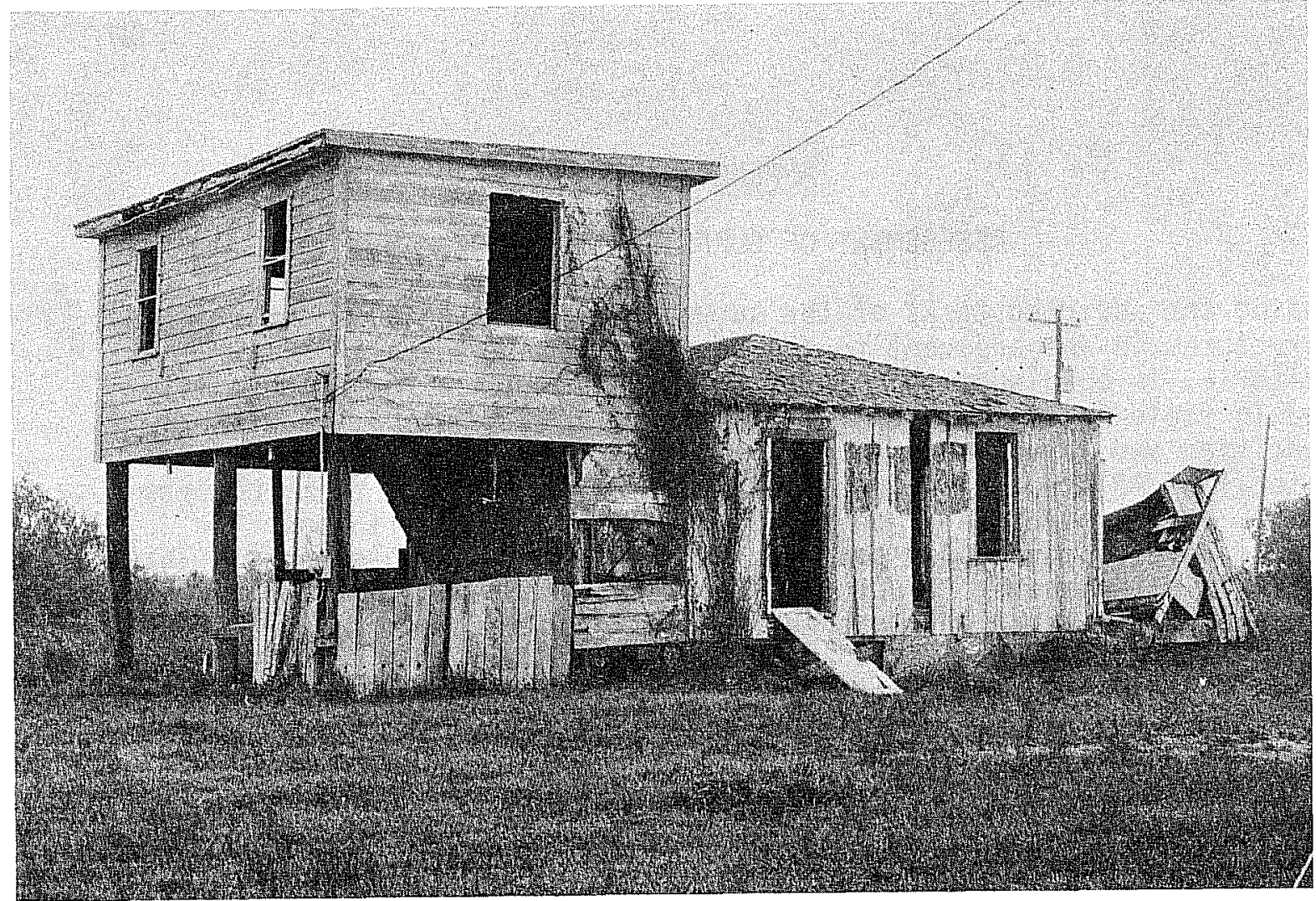

a

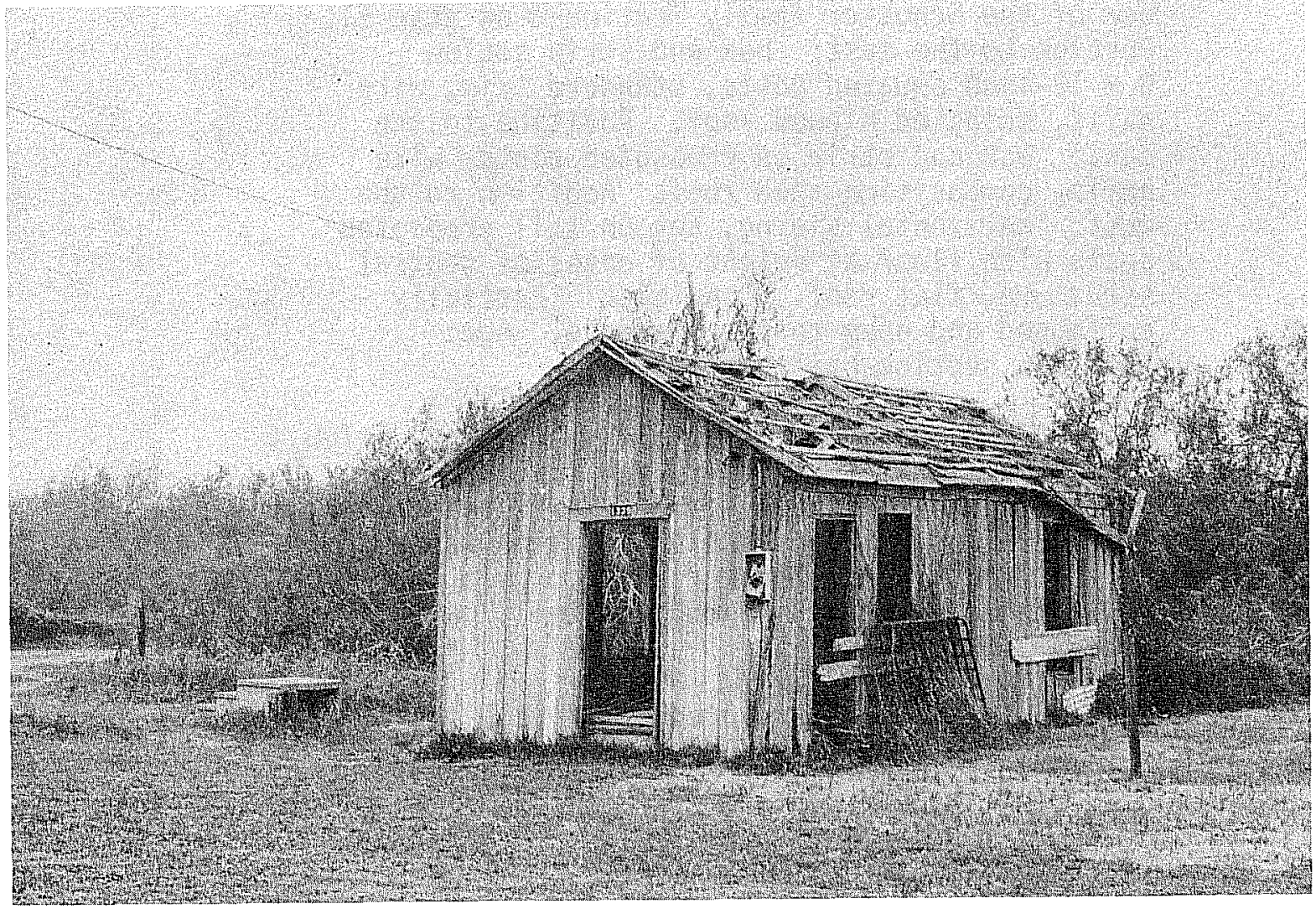

\section{b}

Figure 18. Photographs of Recorded Structures. a, structure 1, "Captain's House," looking west; b, structure 4, looking east. 
4. Sma11, one story box and strip structure, once had shingle roof (Fig. 18,b). Condition: ready to collapse, roof gone. Age: perhaps built ca. 1900.

5. One story, composition shingle siding and roof, set up 1/2-story on creosoted posts. Box and strip garage looks older than house. Condition: good, though needs painting. Age: probably early 1900s with new siding.

6. One story box and strip, 6 over 6 windows all around, up ca. 4 feet on posts, composition shingle roof, probably over wood shingles. Condition: poor, but still enclosed and appears occupied. Age: probably built in late 19th century.

7. One story, vertical siding, shutters in place of windows, hipped roof with composition shingles. Condition: sound, boarded up. Age: looks like typical 1940s beach house.

8. Sma11, one story box and strip house in backyard of Schuster House, shingle roof. Condition: relatively sound, but open to weather. Age: maybe 1920+.

9. Schuster house, one story box and strip supported on large tree trunk sections and occasional creosoted logs, wire nails, wood-shingled roof, much altered, beaded ceilings in central portion. Condition: very poor and collapsing. Age: Difficult to tell, according to local informants built in 1920s, but many details look earlier. Numerous cosmetic changes have been added since.

None of these structures meet the criteria for nomination to the National Register, since they are not good examples of any particular type or period, nor are they of historical importance. There are no standing structures within the survey area on the Quintana side of the river. 



\section{APPENDIX II}

\section{ASSESSMENT OF COAST GUARD STATION}

In August 1980, the Center for Archaeological Research entered into a contract with the U.S. Army Corps of Engineers, Galveston District, to conduct an intensive cultural resource survey and assessment of areas on either side of the mouth of the Brazos River in the vicinity of Freeport, Texas. One stipulation of the contract was that an architectural and historical assessment be made of the United States Coast Guard Station complex. The following report is in response to that particular section of the contract. It was prepared in advance of the final report on the balance of the project, at the request of the Galveston District.

\section{History of the Service}

The United States Coast Guard was established by the First United States Congress. Alexander Hamilton, the first Secretary of the Treasury, saw the need for a seaborne service to help regulate the collection of duties on vessels and goods at coastal ports. In 1790, Congress authorized construction of revenue cutters (Strobridge 1972:i). Known at first as the Revenue-Marine, in 1863 this group was officially designated the Revenue Cutter Service (ibid.:ii).

In 1871, the chief of the Revenue Cutter Service formally organized what had previously been a volunteer life-boat and life-saving service into a branch of the Revenue Cutter Service with paid officers and personnel. In 1878, this group separated from the parent group and became a bureau of the Treasury (Encyclopaedia Britannica 1911:606). Then, in 1915, the Life Saving Service and the Revenue Cutter Service were combined to form the United States Coast Guard. In later years numerous other responsibilities were merged with the Service, such as the Bureau of Lighthouses in 1939, and the Bureau of Marine Inspection and Navigation in 1942 (Strobridge 1972:ii). In peacetime the Coast Guard is part of the Department of Transportation, but in time of war it operates with the U.S. Navy.

\section{History of the Freeport Lifeboat Station}

In 1885, just seven years after the Life Saving Service became an independent group, Congress authorized construction of a station near the site of old Velasco, Texas. Land was acquired in 1887 from the New York and Texas Land Company about two miles north of the present station, and the Velasco Life-Saving Station was built. When a spare boathouse became necessary, in 1910, 1and was leased from J. S. Hollingsworth on the east bank of the mouth of the Brazos River within the new town of Surfside.

An extensive flood on the Brazos in 1913 virtually isolated the Lifeboat Station, and the local people circulated petitions calling for its removal to the site of the boathouse at the mouth of the river. After 
an inspection by a Life Saving Service engineer and the Keeper of the station, the new location was recommended. In 1916, 2066 acres of 1 and which incorporated the boathouse property were purchased from $\mathrm{Mr}$. and Mrs. Ernest D. Dorchester and Mr. and Mrs. Edward F. Simms by what had by this time become the U.S. Coast Guard. According to the deed, ownership of the land would revert to the original owners when it was no longer used for Coast Guard purposes.

The Station house and garage were subsequentry built in 1917, and the present boathouse and launchway in 1935. In 1940, the name of the Velasco Station was changed to Freeport Lifeboat Station.

Assessment

Extensive research into the history of the area has failed to produce any association of the Freeport Lifeboat Station with significant historic events or with the lives of significant people on a local, state, or national level. The buildings on the station are of wood frame construction, with low-pitched, composition shingle roofs (Fig. $19, a, b)$. The station house is raised one story above ground level on wrought iron support pilings. It is well maintained and appears to be in sound physical condition. The architectural style could perhaps be best described as West Indian.

According to the Environmental Assessment 0fficer, 8th Coast Guard District, New Orleans (Lt. P. C. Golden, personal communication), there are a number of other stations of similar design in the Gulf area, although this is the only one remaining which was built on wrought iron pilings. Since the pilings will undoubtedly not be moved with the building, this unique feature would not be maintained if the building were relocated. Architectural drawings for the building are on file with the U.S. Coast Guard (Lt. Jerry Lober, personal communication).

\section{Implications for the Future of the Structures}

The Coast Guard has completed architectural plans for a new station, which will be located farther west along the same shoreline, out of the area to be affected by the Navigation Project. They have no plans to use the. present buildings at the new station. The area where the buildings stand will be seriously impacted by the Navigation Project, and they will have to be removed from the site. When the coast Guard moves out of the present station, it is our understanding that the ownership of the land and its structures will automatically revert to the heirs of the original landowners, under the terms of the 1916 purchase. It will then be up to the owners to decide the proper disposition of the standing structures on the property. They will have the option of selling or otherwise disposing of the buildings or turning them over intact to the Navigation District, which has the responsibility for acquiring the land for the Channel Improvement Project. The Corps of Engineers has announced that it has no use for the Coast Guard Station buildings in its plans for the development of the area. If the 


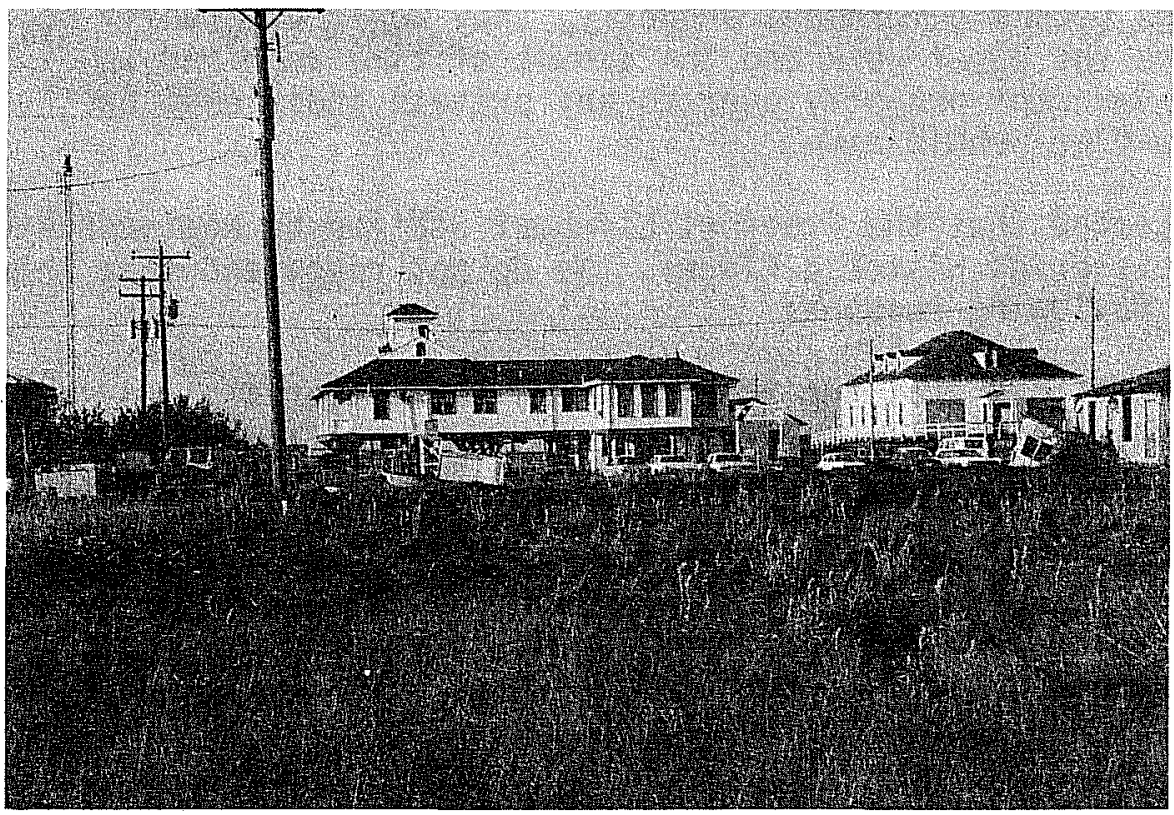

a

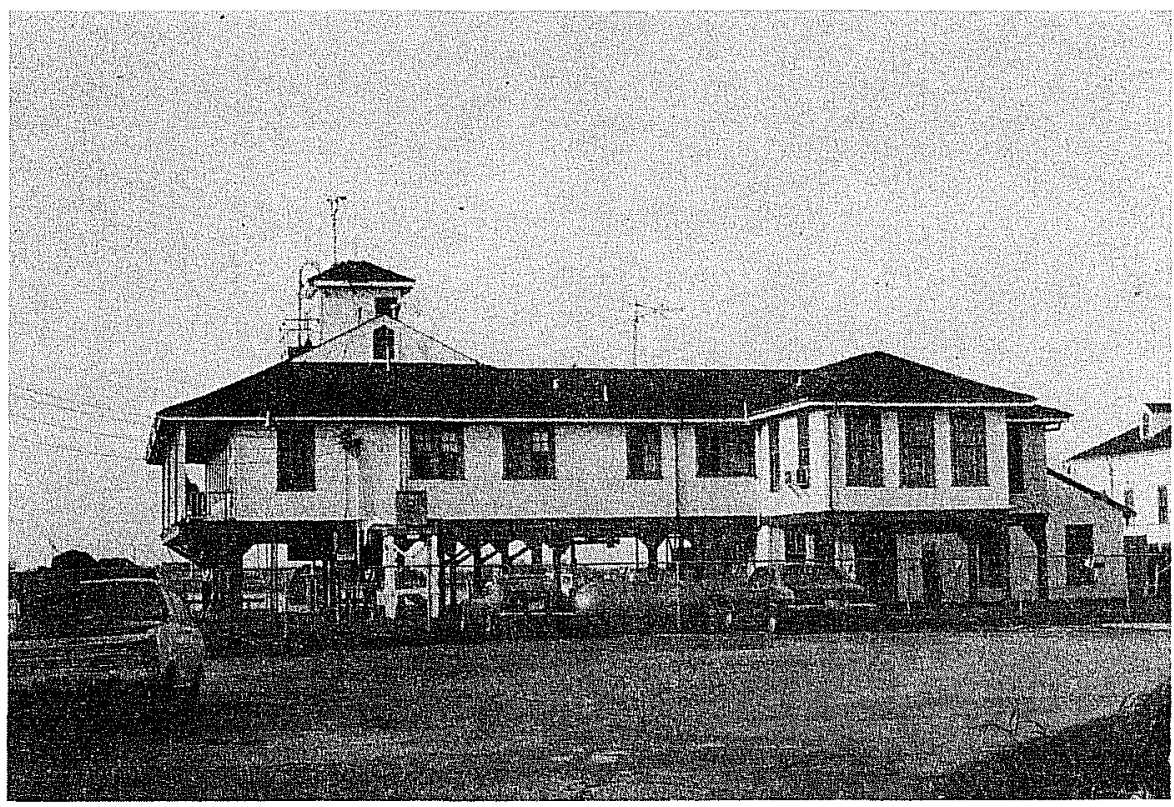

b

Figure 19. Photographs of Lifeboat Station. 
Station buildings become government property, they would eventually be demolished, since the paper work and the amount of time required in order to turn government property over to any private individual or organization would be prohibitive.

It has been suggested that the Freeport Lifeboat Station be nominated to the National Register of Historic Places. We do not recommend that this be done for the following reasons:

1) We do not feel that the Station meets the criteria for nomination.

2) We feel that the best hope for preservation of the building would be the sale or gift to a private group or individual after it has reverted to the heirs of the original landowners, and it is possible that stipulations of National Register status. would impede that process.

3) The only thing that would be accomplished by placing the property on the Register would be to require it to be recorded photographically, and architecturally, and we feel that both these records already exist in. the Corps of Engineers office and in the file of the U.S. Coast Guard. 